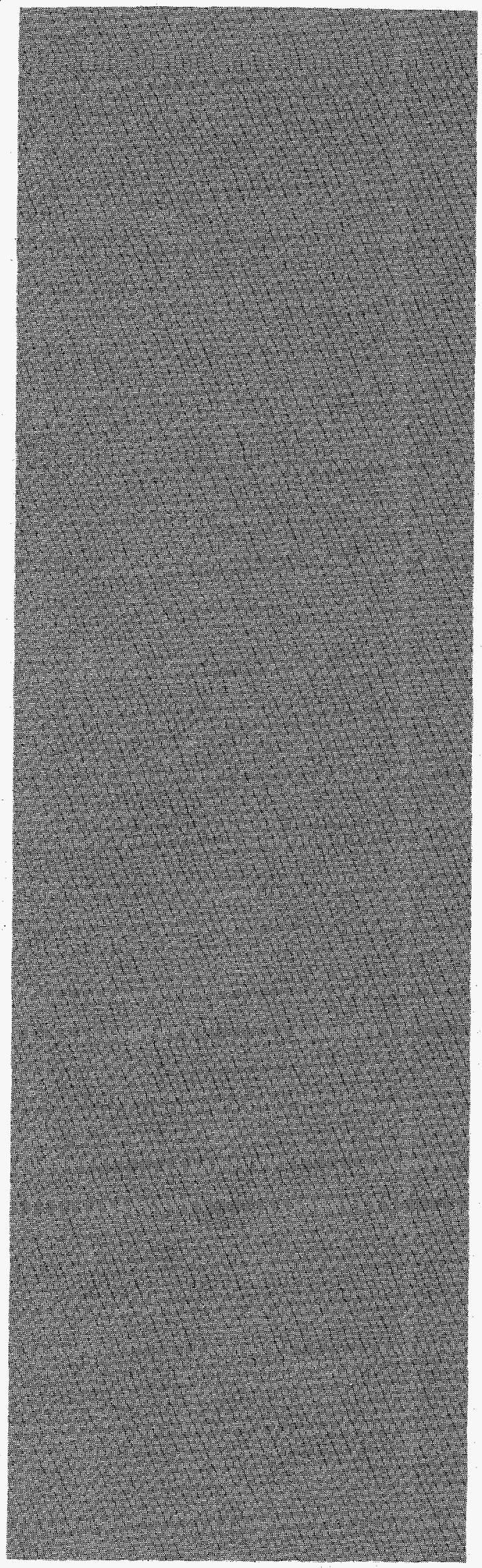

Mixed Waste Treatment Model:

\section{Basis and Analysis}

\section{RFRFIVED \\ OCT 161995 \\ OSTI}

\section{Los Alamos \\ NATIONAL LABORATOAY}

Los Alamos National Laboratory is operated by the University of California for the United States Department of Energy under contract W-7405-ENG-36.

\section{MASTER}


An Affirmative Action/Equal Opportunity Employer

This report was prepared as an account of work sponsored by an agency of the United States Government. Neither The Regents of the University of California, the United States Government nor any agency thereof, nor any of their employees, makes any warranty, express or implied, or assumes any legal liability or responsibility for the accuracy, completeness, or usefulness of any information, apparatus, product, or process disclosed, or represents that its use would not infringe privately owned rights. Reference herein to any specific commercial product, process, or service by trade name, trademark, manufacturer, or otherwise, does not necessarily constitute or imply its endorsement, recommendation, or favoring by The Regents of the University of California, the United States Government, or any agency thereof. The views and opinions of authors expressed herein do not necessarily state or reflect those of The Regents of the University of California, the United States Government, or any agency thereof. 
UC-902 and UC-940

Issued: September 1995

Mixed Waste Treatment Model:

Basis and Analysis

Byron A. Palmer

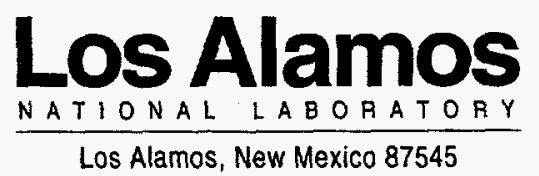




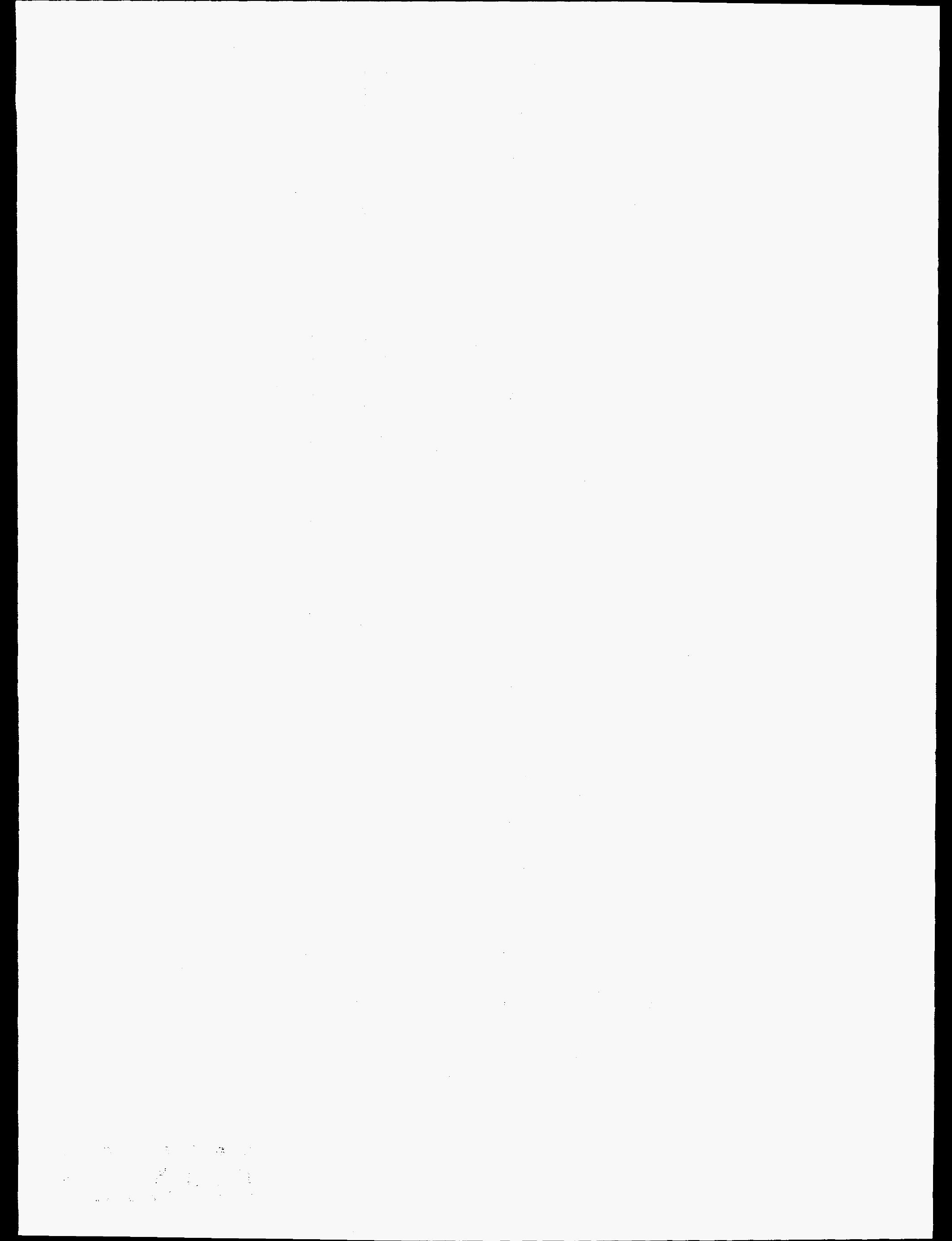




\section{DISCLAIMER}

Portions of this document may be illegible in electronic image products. Images are produced from the best available original document. 


\section{Contents}

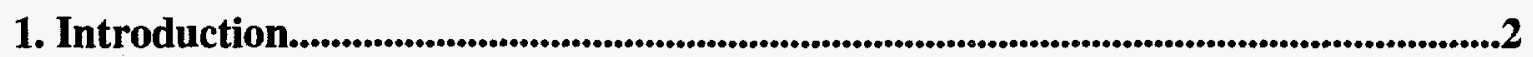

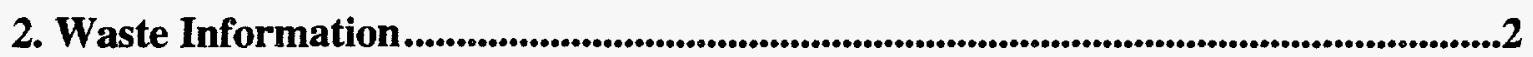

2.1. Mixed Low-Level Waste.......................................................... 3

2.2. TRU and Mixed TRU Waste.................................................. 4

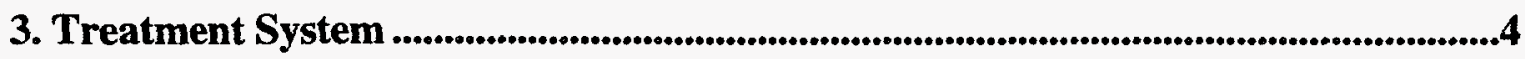

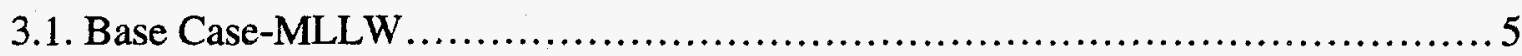

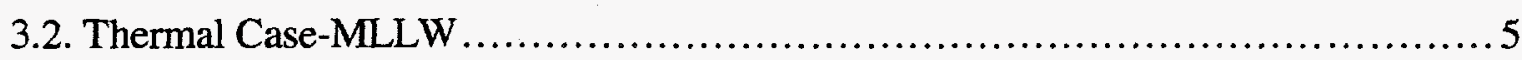

3.3. Nonthermal Case-MLLW....................................................... 5

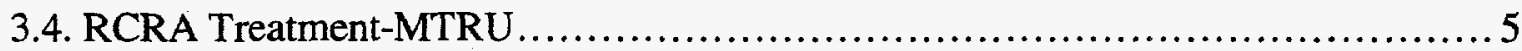

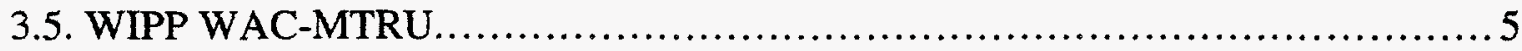

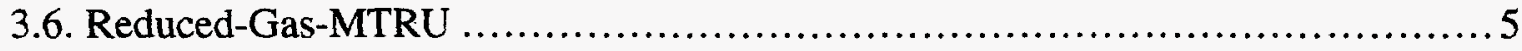

4. Methodology .............................................................................................................................................5

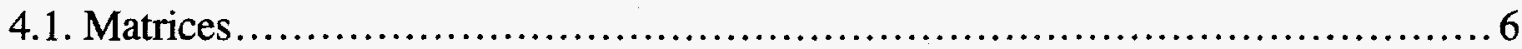

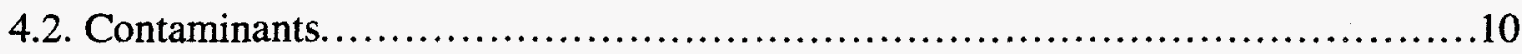

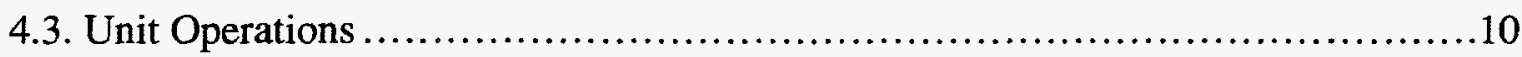

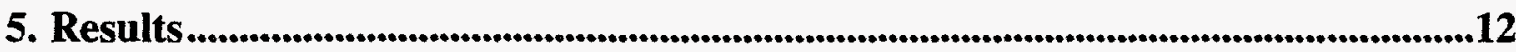

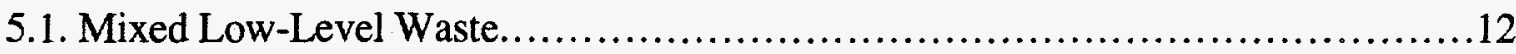

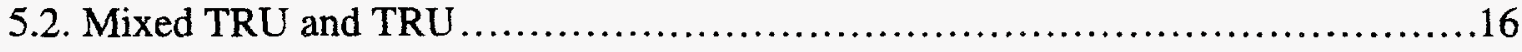

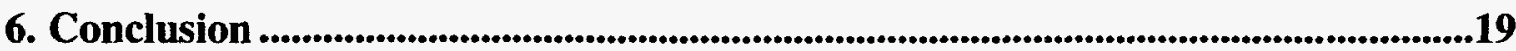

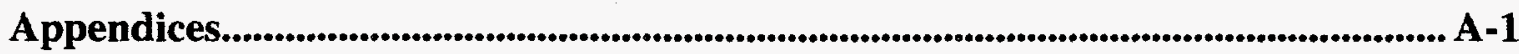

Appendix A - EPA Codes/Contaminants ..................................... A-1

Appendix B - Site/Case Assignements......................................... A-6

Appendix C - Data Base Corrections............................................. A

Appendix D - Process Flow Diagrams.......................................... 


\section{Tables}

Table 2.2 - TRU Volume Scale Factors from MTRU Volumes ................................... 4

Table 4.1 - Matrix Codes for PEIS Analysis of MLLW ............................................... 7

Table 4.2 - Contaminant Groups ........................................................................ 10

Table 4.3 - Unit Operations In PEIS Flow Sheets...................................................... 11

Table 5.1.1 - MLLW Treatment Report Example ..................................................... 13

Table 5.1.2 - MLLW Treatment File Names........................................................... 15

Table 5.2.1 — TRU and MTRU Treatment Files ................................................ 16

Table 5.2.2 - TRU and MTRU Treatment File Example ........................................... 17

Table 5.2.3 - TRU and MTRU Treatment Process Rates Example ............................ 18

Table A —EPA Codes and Contaminant Codes ........................................................A-1

Table B.1 - Site Shipment Assignments................................................................. A-6

Table B.2 - Site Ids, Names, and States ……........................................................ A-8

Table C.1 - Alpha Waste Streams ....................................................................... A-9

Table C. 2 - Projected Volume Corrections ..............................................................A-15

Table C.3 - Projected Volume Based on Mass Projections .......................................... A-25 


\title{
MIXED WASTE TREATMENT MODEL: BASIS AND ANALYSIS
}

\author{
by
}

Byron A. Palmer

\begin{abstract}
The Department of Energy's Programmatic Environmental Impact Statement (PEIS) required treatment system capacities for risk and cost calculation. Los Alamos was tasked with providing these capacities to the PEIS team. This involved understanding the Department of Energy (DOE) Complex waste, making the necessary changes to correct for problems, categorizing the waste for treatment, and determining the treatment system requirements. The treatment system requirements depended on the incoming waste, which varied for each PEIS case. The treatment system requirements also depended on the type of treatment that was desired. Because different groups contributing to the PEIS needed specific types of results, we provided the treatment system requirements in a variety of forms.

In total, some 40 data files were created for the TRU cases, and for the MLLW case, there were 105 separate data files. Each data file represents one treatment case consisting of the selected waste from various sites, a selected treatment system, and the reporting requirements for such a case. The treatment system requirements in their most basic form are the treatment process rates for unit operations in the desired treatment system, based on a 10-year working life and 20-year accumulation of the waste. These results were reported in cubic meters and for the MLLW case, in kilograms as well.

The treatment system model consisted of unit operations that are linked together. Each unit operation's function depended on the input waste streams, waste matrix, and contaminants. Each unit operation outputs one or more waste streams whose matrix, contaminants, and volume/mass may have changed as a result of the treatment. These output streams are then routed to the appropriate unit operation for additional treatment until the output waste stream meets the treatment requirements for disposal. The total waste for each unit operation was calculated as well as the waste for each matrix treated by the unit.

The cost of a treatment system, determined by another group in the PEIS effort, was based on the unit operation volume/mass and the type of unit operation. The risk was determined from these same parameters but was based on chemical and radiological potential releases per mass/volume treated.
\end{abstract}




\section{Introduction}

This report discusses the calculation of the treatment system requirements for the DOE

Mixed Waste portion of the Programmatic Environmental Impact Statement (PEIS). The PEIS approach to the mixed low-level waste was to

1. determine the treatment systems to be analyzed,

2. develop a model of each of these systems,

3. determine the waste to go to each site for each system,

4. calculate the requirements for each site and system,

5. determine the risks involved in each set of sites,

6. determine the costs involved in each set of sites, and

7. bring this information together into a cohesive package.

This report deals with Steps 2 and 4 above. Step 1 was determined by PEIS management. Step 2 was developed by the management team, and flow diagrams for the treatment system were generated by Burdon Musgrave (Analysis of Waste Treatment Requirements for DOE Mixed Wastes, Technical Basis). The high-level flow diagrams for each of the system are given in Appendix D. Step 3 was determined by the PEIS management team and is shown in Appendix B.

The results of Step 4 are passed to other participants for calculation. The amount of information needed by each of the other groups varied but, at a minimum, it consisted of the treatment requirement for each unit operation (see 3. Treatment System). Information needed for risk source terms were derived from treatment volumes split among the required units. This risk analysis is explained in the reports by Argonne National Laboratory and Oak Ridge National Laboratory. The cost analysis was based on the unit operation treatment requirements and is basically an interpolation of a cost $v s$ capacity requirement for each treatment unit.

\section{Waste Information}

A major portion of the effort was directed toward understanding the waste information that was to be used in the analysis. The fundamental information about the waste that is needed for treatment process:

- radiological type [mixed low-level waste (MLLW) or TRU (MTRU and TRU)],

- handling [remote (RH) or contact $(\mathrm{CH})]$,

- alpha designation if MLLW ( $>10 \mathrm{nCi} / \mathrm{g}$ and $<100 \mathrm{nCi} / \mathrm{g})$,

- matrix (the physical nature of the majority of the waste), and

- contaminants (EPA and state regulated).

Each of these factors determine the type of treatment system required and the method for processing the waste through the treatment system. The first three items concerning the radiological nature of the waste, impact the cost and risk because of the need for containment, shielding, and the worker protection. The various categories TRU, MTRU, MLLW CH, MLLW RH, MLLW alpha, etc. are treated in separate cases. The last two pieces of information, matrix and contaminants, determine the requirements for each of the treatment unit operations. Together, all of these factors determine the volume and mass for 
a particular unit operation in a particular analysis. Much of this information was present in the data collected, but some, such as the alpha designation, was not. Additional information concerning volumes, masses, and projected volumes are needed to determine the capacity requirements of the unit operations.

\subsection{Mixed Low-Level Waste}

The information on wastes for the MLLW waste streams came from the 1994 Mixed Waste Inventory Report (MWIR 94), Version 2 A, released in May 1994. The final version was not used for the calculations because it had not been released at the time that the preliminary calculations were needed. Because of this timing, we were unable to switch to the final version. However, the changes are minor and should not have a large impact on the overall results.

Some modifications to the data were necessary to correct for deficiencies in the data from some sites and to put the entire analysis on the same basis. The modifications consisted of expanding the projected volume and correcting some EPA codes that were incorrectly entered.

Some sites were not consistent in reporting future projections and the PEIS management team felt that to adequately project the maximum possible waste feeds, the volume should be corrected slightly. The data base contained multiple fields for projected volume. For the 5 years starting in 1993, there was a projected volume for each year. For the next 5 years, there was one projected volume. The following 20 years were combined in one additional field. The procedure that we used for each waste stream was as follows:

- If the projected volume was completed for all fields, the total projected volume was calculated as the sum of all of the fields, correcting for the last 20-year field so that the basis is 20 years instead of 30 , as reported in MWIR 94.

- If the projected volume was complete for only the first 10 years, then the second 5-year projection was scaled to provide a 20 -year projection by multiplying that 5 -year projection by 4 .

- If the projected volume was complete for only the first five years, and there was a value for the fifth year, that value was scaled by multiplying it by 15 and adding to the first 5 years to give a 20 -year total.

- If only a few of the first 5 years were completed, no projection was done except where information from the sites indicated that they expected to continue to generate that waste. In such a case, this process involved looking at the waste generation termination date in the data base and reading the description and other fields.

For those wastes with incomplete information about projected volumes, we took the last value supplied and extended it for the full 20 years. If the last volume was zero, then no additional volume was added. If, however, the last volume was nonzero, then it was extended appropriately. Table C.2 of Appendix C lists the waste streams affected by this volume projection.

There were a number of waste streams for which there were no projected volumes, but only projected masses. To include those waste streams we used an estimated density for that particular matrix (a bulk density that included the containers as well) to calculate the project volume. Such waste streams are listed in Table C.3 of Appendix C.

Alpha-designated wastes are those that have transuranic radionuclides with $>10 \mathrm{nCi} / \mathrm{g}$ of activity but less than the TRU designation of greater than $100 \mathrm{nCi} / \mathrm{g}$. Alpha waste streams 
are designated because they require more care in handling and more shielding for the workers than ordinary MLLW waste streams do. The MWIR 94 database failed to collect adequately this particular piece of information. Because such alpha wastes affect the cost and risk of a treatment system, an effort was made to go through the data and identify such waste streams. Those waste streams (211) so designated are listed in Appendix C.1.

\subsection{TRU and Mixed TRU Waste}

The TRU and mixed TRU information came from the Interim Mixed Waste Inventory Report (IMWIR) of April 1993 (DOE-NBM-1100). Because the IMWIR does not contain information on the TRU waste (only the mixed TRU waste), Argonne National Laboratory provided scaling factors for the waste volumes. These factors were used to calculate the treatment requirements for the TRU waste based on the mixed TRU volumes and characteristics. This process was necessary because the TRU information did not have consistent matrices for use in the treatment system calculations.

Table 2.2 - TRU Volume Scale Factors from MTRU Volumes

\begin{tabular}{|l|r|r|}
\hline SITE NAME & Inventory & Generation \\
\hline Argonne National Laboratory - East & 7.730 & 145.060 \\
\hline Argonne National Laboratory - West & 1.000 & 1.000 \\
\hline Energy Technology Engineering Center & 1.000 & 1.000 \\
\hline Idaho National Engineering Laboratory & 1.000 & 32.560 \\
\hline Los Alamos National Laboratory & 1.000 & 1.000 \\
\hline Lawrence Berkeley Laboratory & 0.000 & 0.000 \\
\hline Lawrence Livermore National Laboratory & 105.260 & 97.370 \\
\hline Mound Plant & 82.260 & $1,321.560$ \\
\hline Nevada Test Site & 1.000 & 1.000 \\
\hline Oak Ridge National Laboratory & 1.010 & 1.880 \\
\hline Paducah Gaseous Diffusion Plant & 1.000 & 1.000 \\
\hline Rocky Flats Plant & 1.000 & 4.350 \\
\hline Hanford Site & 59.400 & 1.770 \\
\hline Sandia National Laboratory-New Mexico & 1.000 & 1.000 \\
\hline Savannah River Site & 1.070 & 21.600 \\
\hline Waste Isolation Pilot Project & 1.000 & 1.000 \\
\hline West Valley Demonstration Project & 1.000 & 1.000 \\
\hline
\end{tabular}

The TRU and mixed-TRU waste was handled differently than the MLLW. The major difference was that only matrices, not contaminants, were used in the TRU calculations, whereas both contaminants and matrices drove the MLLW calculations. Also, the matrices were the original 20 IMWIR rather than the MWIR 94 values.

\section{Treatment System}

As shown in Appendix D, the treatment systems are composed of unit operations. Each unit operation performs a function on the input waste stream and has output streams that go to other operations or to a final form that can be released or disposed of appropriately. These unit operations are connected in to perform a complete treatment of the waste, beginning with the receiving and sorting operation and capturing all aspects of the treatment process. 
The six different treatment systems, three for MLLW and three for MTRU waste, are described below.

\subsection{Base Case-MLLW}

The base case for the PEIS is a treatment system that models closely what is presently in place for treating some of the waste within the DOE Complex. The primary unit operation for destruction of toxic organics is the incinerator module, which consists of unit operations 470 and 480 . The primary stabilization unit operation is the grout unit (although there are two: one for ash-type wastes and one for debris).

\subsection{Thermal Case-MLLW}

The thermal case differs only slightly from the base case in that the primary toxic organic destruction unit is the incinerator. The major change is in the stabilization units, which employ vitrification for the glass-type wastes and metal melting for metallic-type wastes. These technologies reduce the amount of waste that would be sent to disposal and thus would reduce the disposal costs.

\subsection{Nonthermal Case-MLLW}

The nonthermal case uses only technologies that have temperatures $<350^{\circ} \mathrm{C}$. Of the three treatment systems modeled, this is the least understood. It is not clear what technologies would actually be used for the primary treatment units, and therefore the calculated values are based on very generic treatment operations.

\subsection{RCRA Treatment-MTRU}

For the MTRU and TRU cases, a treatment system was developed to treat the waste for hazardous contaminants similar to the base-case in MLLW. This process involved incineration and grouting as the primary treatment systems.

\subsection{WIPP WAC-MTRU}

Rather than treat the MTRU and TRU waste to RCRA treatment standards to meet landdisposal requirements (LDR), this treatment system was developed to only prepare the waste for acceptance at the Waste Isolation Pilot Plant (WIPP). This is a simpler treatment system.

\subsection{Reduced-Gas-MTRU}

One of the concerns of shipping untreated waste to WIPP is generation of potentially hazardous gas caused by the radiation acting upon the matrix and contaminants. This treatment system is designed to reduce the possibility of generating such gas as well as preparing the waste for WIPP.

\section{Methodology}

When the first model of the treatment system was built, it was done using a spreadsheet. The only criterion used for selection of the flow of the waste through the treatment system were based on the matrix. The waste stream "splits" at each unit operation were determined by a rough approximation of the contaminants that might be present. This resulted in predicted treatment systems where unit operations were not needed because that particular 
site had no waste with contaminants that required such a unit. One example is a site with no mercury-contaminated waste being required to have a mercury-stabilization unit. Because of the complexity caused by the different contaminants, we decided to use a more sophisticated model to predict treatment system requirements. However, because of the time frame for TRU information, we were not able to implement such a system for those calculations.

Modeling of the treatment system is based on the following assumptions:

1. each unit operation is complete in itself,

2. each unit operation has waste-acceptance criteria that list matrix and contaminants acceptable for treatment,

3. each unit operation has one or more output streams,

4. each output stream may have different characteristics (such as matrix and contaminants),

5. the output stream(s) matrix, contaminants, and volume depend on the unit's input characteristics (matrix and contaminants),

6. the total mass (volume) is conserved in each unit operation, and

7. the output waste streams are directed to the next unit operation as appropriate for that combination of matrix and contaminants.

For the MTRU and TRU calculations, our only consistent data were volumes, so volume conservation was used. For the MLLW where we predicted densities and where we had some mass information, we conserved both mass and volume except where it was clear that the process made a substantial change in the volume (for example, in the shredding operation).

The program used to calculate the treatment system requirements was based on treating each unit operation as an entity. The description of the treatment system was "compiled" into an interpreted language that drove each unit operation. In this way, different treatment systems could use the same unit operations (such as the receiving and sorting) without redefining each one. This also meant that treatment systems can include recycling and that a unit operation may treat different portions of the input waste stream differently, depending on the step of the process in which the waste is located.

\subsection{Matrices}

The following tables show the matrices used in the MLLW analysis. Because of the large number of matrices, Argonne National Laboratory, who handled the first phase of the risk calculations, asked us to reduce that number to a more manageable size by aggregating them (ANL codes). Because some of the matrix codes are more generic, those matrix numbers were assigned multiple ANL codes. For example: matrix 1000, which is the general heading for all aqueous liquids and slurries. But slurries, matrix 1200-1290 are treated differently than wastewaters, matrix 1100-1190. We assumed that such split matrix codes would proportion themselves to the ANL codes based on the relative volumes of the unambiguous waste streams being treated at that site. So if a site had a 1000 matrix code stream and the stream volumes of waste for ANL codes 1 and 2 were 60 and $40 \%$ respectively, the 1000 matrix code stream would be split $60 \%$ to ANL code 1 and $40 \%$ to ANL code 2 . If no other waste was treated in ANL codes 1 and 2 at the site, the ratio would be set at $50 \%$ to each. 
Table 4.1 - Matrix Codes for PEIS Analysis of MLLW

\begin{tabular}{|l|c|c|}
\hline \multicolumn{1}{|c|}{ Name } & Matrix Code & ANL Code \\
\hline Aqueous Liquids/Slurries & 1000 & $1-2$ \\
\hline Wastewaters & 1100 & 1 \\
\hline Acidic Wastewaters & 1110 & 1 \\
\hline Basic Wastewaters & 1120 & 1 \\
\hline Neutral Wastewaters & 1130 & 1 \\
\hline Cyanide Wastewaters & 1140 & 1 \\
\hline Uncategorized Wastewaters & 1190 & 1 \\
\hline Aqueous Slurries & 1200 & 2 \\
\hline Acidic Aqueous Slurries & 1210 & 2 \\
\hline Basic Aqueous Slurries & 1220 & 2 \\
\hline Neutral Aqueous Slurries & 1230 & 2 \\
\hline Cyanide Aqueous Slurries & 1240 & 2 \\
\hline Uncategorized Aqueous Slurries & 1290 & 2 \\
\hline Organic Liquids & 2000 & $3-6$ \\
\hline Aqueous/Organic Liquids & 2100 & $3-4$ \\
\hline Aqueous/Halogenated Organic Liquids & 2110 & 3 \\
\hline Aqueous/Nonhalogenated Organic Liquids & 2120 & 4 \\
\hline Uncategorized Aqueous/Organic Liquids & 2190 & $3-4$ \\
\hline Pure Organic Liquids & 2200 & $5-6$ \\
\hline Halogenated Pure Organic Liquids & 2210 & 5 \\
\hline Nonhalogenated Pure Organic Liquids & 2220 & 6 \\
\hline Uncategorized Pure Organic Liquids & 2290 & $5-6$ \\
\hline Uncategorized Organic Liquids & 2900 & $3-6$ \\
\hline Solid Process Residues & 3000 & $7-13$ \\
\hline Inorganic Process Residues & 3100 & $7-10$ \\
\hline Inorganic Particulates & 3110 & 7 \\
\hline Ash & 3111 & 7 \\
\hline Sand Blasting Media & 3112 & 7 \\
\hline Absorbed Aqueous Liquids & 3113 & 7 \\
\hline Absorbed Organic Liquids & 3114 & 7 \\
\hline Ion Exchange Media & 3115 & 7 \\
\hline Calcined Solids & 3116 & 7 \\
\hline Uncategorized Inorganic Particulates & 3119 & 7 \\
\hline Inorganic Sludges & 3120 & 8 \\
\hline Wastewater Treatment Sludges & 3121 & 8 \\
\hline Pond Sludges & 3122 & 8 \\
\hline Off-Gas Treatment Sludges & 3123 & 8 \\
\hline Plating Waste Sludges & 3124 & 8 \\
\hline Reprocessing Sludges & 3125 & 8 \\
\hline Uncategorized Inorganic Sludges & 3129 & 8 \\
\hline Paint Waste & 3130 & 7 \\
\hline Paint Chips/Solids & 3131 & 7 \\
\hline Paint Liquids/Sludge & 3132 & 7 \\
\hline
\end{tabular}




\begin{tabular}{|l|c|c|}
\hline Name & Matrix Code & ANL Code \\
\hline Uncategorized Paint Waste & 3139 & 7 \\
\hline Salt Waste & 3140 & 9 \\
\hline Chloride Salts & 3141 & 9 \\
\hline Sulfate Salts & 3142 & 9 \\
\hline Nitrate Salts & 3143 & 9 \\
\hline Uncategorized Salt Waste & 3149 & 9 \\
\hline Solidified Process Residues & 3150 & 10 \\
\hline Uncategorized Inorganic Process Residues & 3190 & $7-10$ \\
\hline Organic Process Residues & 3200 & $11-13$ \\
\hline Organic Particulates nonhalogenated & 3210 & 11 \\
\hline Activated Carbon nonhalogenated & 3211 & 11 \\
\hline Organic Resins nonhalogenated & 3212 & 11 \\
\hline Organic Absorbents nonhalogenated & 3213 & 11 \\
\hline Uncategorized Organic Particulates nonhalogenated & 3219 & 11 \\
\hline Organic Sludges nonhalogenated & 3220 & 11 \\
\hline Biological Materials nonhalogenated & 3221 & 11 \\
\hline Nonhalogenated Organic Sludges & 3223 & 11 \\
\hline Uncategorized Organic Sludges nonhalogenated & 3229 & 11 \\
\hline Organic Particulates halogenated & 3210 & 12 \\
\hline Activated Carbon halogenated & 3211 & 12 \\
\hline Organic Resins halogenated & 3212 & 12 \\
\hline Organic Absorbents halogenated & 3213 & 12 \\
\hline Uncategorized Organic Particulates halogenated & 3219 & 12 \\
\hline Organic Sludges halogenated & 3220 & 12 \\
\hline Biological Materials halogenated & 3221 & 12 \\
\hline Halogenated Organic Sludges & 3222 & 12 \\
\hline Uncategorized Organic Sludges halogenated & 3229 & 12 \\
\hline Organic Chemicals nonhalogenated & 3230 & 13 \\
\hline Organic Chemicals halogenated & 3230 & 14 \\
\hline Uncategorized Organic Process Residues & 3290 & $11-14$ \\
\hline Uncategorized Process Residues & 3900 & $7-14$ \\
\hline Soils & 4000 & $15-16$ \\
\hline Contaminated Soils & 4100 & 15 \\
\hline Contaminated Soils/Debris & 4200 & 16 \\
\hline Uncategorized Soils & 4900 & $15-16$ \\
\hline Debris Waste & 5000 & $17-20$ \\
\hline Metal Debris & 5100 & 17 \\
\hline Metal Debris without Pb or Cd & 5110 & 17 \\
\hline Lead Containing Metal Debris & 5120 & 17 \\
\hline Cadmium Containing Metal Debris & 5130 & 17 \\
\hline Uncategorized Metal Debris & 5190 & 17 \\
\hline Inorganic Nonmetal Debris & 5200 & 18 \\
\hline Concrete Debris & 5220 & 18 \\
\hline Glass Debris & & 18 \\
\hline
\end{tabular}




\begin{tabular}{|l|c|c|}
\hline \multicolumn{1}{|c|}{ Name } & Matrix Code & ANL Code \\
\hline Ceramic/Brick Debris & 5230 & 18 \\
\hline Rock Debris & 5240 & 18 \\
\hline Asbestos Debris & 5250 & 18 \\
\hline Uncategorized Inorganic Nonmetal Debris & 5290 & 18 \\
\hline Combustible Debris & 5300 & 19 \\
\hline Plastic/Rubber Debris & 5310 & 19 \\
\hline Leaded Gloves/Aprons Debris & 5311 & 19 \\
\hline Halogenated Plastic Debris & 5312 & 19 \\
\hline Nonhalogenated Plastic Debris & 5313 & 19 \\
\hline Uncategorized Plastic/Rubber Debris & 5319 & 19 \\
\hline Wood Debris & 5320 & 19 \\
\hline Paper/Cloth Debris & 5330 & 19 \\
\hline Graphite Debris & 5340 & 19 \\
\hline Biological Debris & 5350 & 19 \\
\hline Uncategorized Combustible Debris & 5390 & 19 \\
\hline Heterogeneous Debris & 5400 & 20 \\
\hline Composite Filters & 5410 & 20 \\
\hline Predominantly Metal Debris & 5420 & 20 \\
\hline Predominantly Inorganic Nonmetal Debris & 5430 & 20 \\
\hline Predominantly Combustible Debris & 5440 & 20 \\
\hline Asphalt Debris & 5450 & 20 \\
\hline Uncategorized Heterogeneous Debris & 5490 & 20 \\
\hline Special Waste & 6000 & $21-29$ \\
\hline Lab Packs & 6100 & $21-23$ \\
\hline Organic Lab Packs & 6110 & 21 \\
\hline Aqueous Lab Packs & 6120 & 22 \\
\hline Solid Lab Packs & 6130 & 23 \\
\hline Scintillation Cocktails & 6140 & 21 \\
\hline Uncategorized Lab Packs & 6190 & $21-23$ \\
\hline Reactive Metals & 6200 & 24 \\
\hline Bulk Reactive Metals & 6210 & 24 \\
\hline Components Contaminated with Reactive Metals & 6220 & 24 \\
\hline Pyrophoric Fines & 6230 & 24 \\
\hline Uncategorized Reactive Metals & 6290 & 24 \\
\hline Explosives/Propellants & 6300 & 25 \\
\hline Compressed Gases/Aerosols & 6400 & 26 \\
\hline Inherently Hazardous Waste & 7000 & $27-32$ \\
\hline Elemental Mercury & 7100 & 27 \\
\hline Elemental Lead & 7200 & 28 \\
\hline Nonactivated Lead & 7210 & 28 \\
\hline Activated Lead & 7220 & 28 \\
\hline Beryllium Waste & 29 \\
\hline Batteries & 300 & 30 \\
\hline Lead Acid Batteries & & \\
\hline
\end{tabular}




\begin{tabular}{|l|c|c|}
\hline Name & Matrix Code & ANL Code \\
\hline Cadmium Batteries & 7420 & 30 \\
\hline Uncategorized Batteries & 7490 & 30 \\
\hline Unknown Matrix & 8000 & 31 \\
\hline Unknown Liquids & 8100 & 31 \\
\hline Unknown Solids & 8200 & 31 \\
\hline Uncategorized Unknown & 8900 & 31 \\
\hline Final Waste Forms & 9000 & 32 \\
\hline Cement Forms & 9100 & 32 \\
\hline Vitrified Forms & 9200 & 32 \\
\hline Metal Forms & 9300 & 32 \\
\hline Polymer Forms & 9400 & 32 \\
\hline Other Forms & 9900 & 32 \\
\hline
\end{tabular}

\subsection{Contaminants}

Contaminants are important in the treatment system calculations because they drive the treatment requirements. Because there are a large number of EPA defined contaminants, we decided to consolidate these into a number of basic categories, which are listed in Table 4.2. These contaminant groups were only used for the MLLW calculations, and not for the TRU calculations.

Table 4.2 - Contaminant Groups

\begin{tabular}{|c|l|}
\hline Code & Description \\
\hline O & Toxic Organics \\
\hline I & Ignitable \\
\hline C & Corrosive \\
\hline A & Acid Reactive \\
\hline M & Toxic Metals \\
\hline H & Mercury \\
\hline W & Water Reactive \\
\hline R & Reactive \\
\hline E & Explosive \\
\hline F & Halogenated \\
\hline S & Inorganic Ignitable \\
\hline
\end{tabular}

Most of the EPA and other codes listed in MWIR 94 were assigned one or more of the codes listed in Table 5.2.1 (See Appendix A). Then each waste was reviewed and the collection of contaminant codes was assembled. This process works fairly well as a grouping for the two treatment systems involving incinerators. For the nonthermal treatment system, the grouping is not really adequate for a detailed study; however, given the understanding and the level of modeling, they do not introduce much more uncertainty.

\subsection{Unit Operations}

The following list gives all of the unit operations and a brief description of their function. Many of the unit operations appear in all three treatment systems. 
Table 4.3 - Unit Operations In PEIS Flow Sheets

Units 110, 210, 310, 410, 510, 610, 710, 810, 910 - Receive and Sort

Receive waste streams of the corresponding 1000-level matrix (that is unit 110 receives all aqueous 1000 streams) and route the streams to the appropriate initial treatment unit.

\section{Units 140, 240, 340, 440 - Neutralization}

Neutralize corrosive contaminants present in waste matrices $1000-4000$, respectively.

\section{Units 150, 250 - Solids Separation}

Filtration units for aqueous and organic waste streams, respectively.

\section{Unit 180 - Evaporator}

Removes the salts and toxic metals from an aqueous waste stream through evaporation.

The condensate goes on to a condenser unit (Unit 190) and the bottoms (sediments) are sent to a stabilization process.

Unit 190 - Condenser

Condenses the aqueous stream from the evaporator (180) for recycling or release. Mercury is also separated.

\section{Unit 195 - Polymer Encapsulation}

Encapsulates the solids with high salt content that cannot be grouted.

\section{Unit 270 - Organic Destruction}

Organic destruction unit for aqueous streams.

\section{Unit 335 - Sludge Washing}

Accepts solid wastes and performs nonthermal separation of organics.

\section{Units 350, 450, 550, 650, 750 - Solid Separation}

Large-scale separation processes (such as debris removal from soils) and route solid waste streams for further processing.

\section{Unit 370 - Aqueous Organic Destruction}

Treats concentrated organic liquids by oxidation.

\section{Unit 435 - Soil Washer}

Similar to Unit 335 for soils.

\section{Unit 470 - Thermal Destruction}

An incinerator or thermal destruction unit capable of handling solid and liquid feed.

\section{Unit 480 - Secondary Burner}

Receives the offgas from the thermal destruction unit (470) and subjects it to a second thermal oxidation for increased destruction of organics.

\section{Unit 490 - Offgas Treatment}

This represents the scrubbing and filtration operations of offgas treatment. Outputs are stack gas, particulates, and caustic aqueous blowdown.

\section{Unit 535 - Debris Washing}

Removes organics from debris feed stream.

\section{Unit 540 - Shred}

Shreds debris waste streams preparatory to pelletizing and grouting. 
Unit 560 - Mercury Distillation

Distills waste to generate a mercury recycle stream.

\section{Unit 570 - Thermal Desorption}

Removes the volatile organics from debris wastes through heating.

\section{Unit 595 - Mercury Solidification}

Accepts elemental mercury and produces a solid mercury compound (for example, $\mathrm{HgS}$ ).

Unit 640 - Chemical Oxidation/Reduction

Oxidizes or reduces special wastes, inherently hazardous wastes, and any other form requiring special treatment for reactive matrices or contaminants.

\section{Unit 670 - Glass Melter}

Accepts inorganic solids to produce a vitrified final form.

\section{Unit 695 - Pelletize}

Pelletizes debris waste preparatory to grouting. This unit is expected to halve the volume of the debris waste stream.

Unit 740 - Chemical/Physical Separation

Chemical or physical separation techniques to remove designated inherently hazardous materials (for example, mercury) from the waste matrix.

\section{Unit 770 - Metals Melt/Slag}

Melts metal debris to produce final form.

\section{Unit 795 - Grout}

Grouts solid wastes of the 3000 and 4000 series (solid process residues and soils).

\section{Unit 796 - Grout}

Grouts debris wastes. This unit is distinct from unit 795 based on the assumption of relaxed standards for debris grouting.

\section{Units 850, 950 - Characterization}

Characterize matrix 8000 and 9000 waste streams to determine what treatment, if any, is required. Further treatment was not defined for these streams.

\section{Unit 895 - Recycle/Stabilization}

Remove contaminants from inherently hazardous materials and recycle the remainder.

\section{Results}

Because of the large amount of data generated, it cannot all be presented in this report. Electronic files of all of the data files are available upon request or can be obtained at

$$
\text { URL ftp://mwir.lanl.gov/public/peis/ . }
$$

\subsection{Mixed Low-Level Waste}

The mixed low-level waste treatment systems were calculated for all sites with no shipment of waste, for 11 sites, for 7 sites, for 4 sites, and for 1 site. In all of these calculations, the aqueous waste (matrix 1000-type wastes) at a site was not shipped but the residues from aqueous waste treatment (such as evaporator bottoms (residues) and solids from separation processes) are shipped to an other site for treatment. 
An example of a MLLW report is shown below (Table 5.1.1) for the MLLW CH nonalpha four-site case with the basic treatment system (debris-residue grouted). Because aqueous waste was not shipped in any of the analyses, the aqueous waste had to be treated at each site. The residues from the treatment were shipped for further treatment, however. Shown below is a report for the first site, Idaho National Engineering Laboratory, with shipments from Argonne West, General Atomics, Grand Junction, Los Alamos, and Pantex. The only treatment at these sites are for the water portion of the aqueous waste. All other portions, including the solids separated from the water and the evaporator solids, are shipped for further treatment to Idaho.

The first column of the report is the treatment unit; final waste forms have no number. Input waste streams are in the $1000 \mathrm{~s}$, and the unit operations are in the $100 \mathrm{~s}$. The second column is the name of the unit, the third column is the volume (in $\mathrm{m}^{3}$ ) of the waste, and the fourth column is the mass of the waste (in $\mathrm{kg}$ ). This example represents only the first such treatment site; there are three more sites for this particular case.

Table 5.1.1-MLLW Treatment Report Example

\begin{tabular}{|c|c|c|c|}
\hline \multicolumn{4}{|c|}{$\begin{array}{l}\text { Fri Aug } 19 \quad 14: 19: 38 \quad 1994 \\
\text { Workoff rate }=10.0\end{array}$} \\
\hline \multicolumn{4}{|c|}{ Clear and Total Aqueous General Atomics } \\
\hline 1000 & Aqueous Waste Streams & 2.5184 & 2420.2 \\
\hline 110 & Receive and sort & 2.5184 & 2420.2 \\
\hline 150 & Solids Separation & 2.5184 & 2420.2 \\
\hline 140 & Neutralize & 2.1831 & 2098.0 \\
\hline 180 & Evaporate & 2.4932 & 2396.0 \\
\hline 190 & Condenser & 2.2398 & 2152.5 \\
\hline 270 & $\begin{array}{l}\text { Organic Destruction } \\
\text { Water Recycle }\end{array}$ & $\begin{array}{l}1.6280 \\
2.2385\end{array}$ & $\begin{array}{l}1564 \cdot 5 \\
2151 \cdot 2\end{array}$ \\
\hline \multicolumn{4}{|c|}{ clear and Total Aqueous Grand Junction Project Office } \\
\hline 1000 & Aqueous Waste Streams & 0.0701 & 67.4 \\
\hline 110 & Receive and Sort & 0.0701 & 67.4 \\
\hline 150 & Solids Separation & 0.0701 & 67.4 \\
\hline 140 & Neutralize & 0.0215 & 20.6 \\
\hline 180 & Evaporate & 0.0694 & 66.7 \\
\hline 190 & Condenser & 0.0621 & 59.7 \\
\hline 270 & Organic Destruction & 0.0478 & 46.0 \\
\hline & Water Recycle & 0.0621 & 59.7 \\
\hline \multicolumn{4}{|c|}{ Clear and Total Aqueous Los Alamos National Laboratory } \\
\hline 1000 & Aqueous Waste Streams & 4.1935 & 4030.0 \\
\hline 110 & Receive and Sort & 4.1935 & 4030.0 \\
\hline 150 & Solids Separation & 4.1935 & 4030.0 \\
\hline 140 & Neutralize & 4.1516 & 3989.7 \\
\hline 180 & Evaporate & 4.1516 & 3989.7 \\
\hline 190 & Condenser & 3.7322 & 3586.7 \\
\hline 270 & Organic Destruction & 0.0000 & 0.0 \\
\hline & Water Recycle & 3.7322 & 3586.7 \\
\hline
\end{tabular}




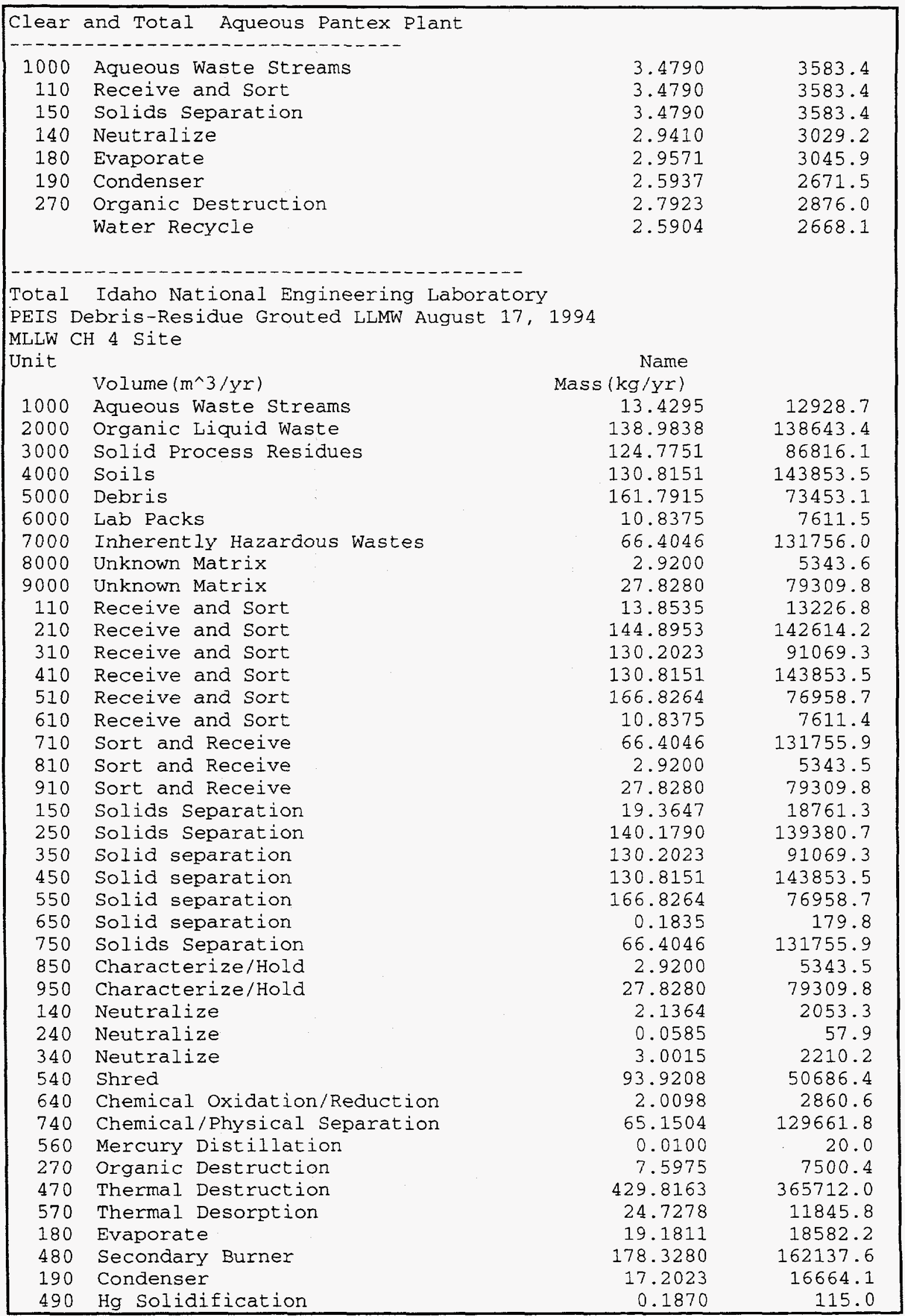




\begin{tabular}{|llrr|}
\hline 195 & Polymer Solidification & 19.0093 & 15966.5 \\
695 & Pelletize & 92.6844 & 50094.1 \\
795 & Grout & 218.2163 & 211226.9 \\
796 & Grout & 46.3422 & 50094.1 \\
895 & 1.2442 & 2074.1 \\
& Wecycle/Stabilization & 17.1895 & 16651.8 \\
& Polymer & 38.0186 & 31933.0 \\
Hg Solid & 0.3741 & 229.9 \\
Hg Recycle & 0.0075 & 15.0 \\
Pb Recycle & 61.8929 & 123178.7 \\
Recycled/Stabilized & 1.2442 & 2074.1 \\
Grout & 343.9260 & 339717.3 \\
Stack & 238.6058 & 177748.6 \\
\hline
\end{tabular}

Table 5.1.2 contains the file names for all the cases analyzed. For each of the contact handled cases that are nonalpha, there are two files. The file with the $\mathrm{x}$ has three streams removed; the Hanford tank waste, and the Rocky Flats saltcrete and pondcrete. The To Calculation file has the volumes and masses going to a particular unit, and the From Calculation file has the waste streams from the particular unit. Using these numbers, Argonne could be more easily track the contaminants.

Table 5.1.2 - MLLW Treatment File Names

\begin{tabular}{|c|c|c|c|c|c|}
\hline \multicolumn{3}{|c|}{ Treatment Case } & Standard & To Calculation & From Calculation \\
\hline Sites & Hand & alpha & \multicolumn{3}{|c|}{ File Names } \\
\hline 1 & $\overline{\mathrm{CH}}$ & No & lc1.out & lc11f.out & lc11t.out \\
\hline 1 & $\overline{\mathrm{CH}}$ & No & lclx.out & lclxf.out & lc1xt.out \\
\hline$\overline{4}$ & $\overline{\mathrm{CH}}$ & No & lc4.out & lc4f.out & lc4t.out \\
\hline 4 & $\overline{\mathrm{CH}}$ & No & lc4x.out & lc $4 \times f$ fout & lc4xt.out \\
\hline 7 & $\overline{\mathrm{CH}}$ & No & lc7.out & lc7f.out & lc7t.out \\
\hline 7 & $\overline{\mathrm{CH}}$ & No & lc7x.out & lc7xf.out & lc7xt.out \\
\hline 11 & $\overline{\mathrm{CH}}$ & No & lc11.out & lc11xf.out & lc11xt.out \\
\hline 11 & $\overline{\mathrm{CH}}$ & No & lc11x.out & lc1f.out & lc1t.out \\
\hline 50 & $\overline{\mathrm{CH}}$ & No & lc50.out & lc50f.out & lc50t.out \\
\hline 50 & $\overline{\mathrm{CH}}$ & No & Ic50x.out & lc50xf.out & lc50xt.out \\
\hline 1 & $\mathrm{CH}$ & Yes & Tac1.out & lacl1f.out & lac11t.out \\
\hline 4 & $\mathrm{CH}$ & Yes & lac1x.out & lac1xf.out & lac1xt.out \\
\hline$\overline{4}$ & $\overline{\mathrm{CH}}$ & Yes & lac4.out & lac4f.out & lac4t.out \\
\hline 4 & $\overline{\mathrm{CH}}$ & Yes & lac4x.out & lac4xf.out & lac4xt.out \\
\hline 7 & $\overline{\mathrm{CH}}$ & Yes & lac7.out & lac7f.out & lac7t.out \\
\hline 7 & $\overline{\mathrm{CH}}$ & Yes & Tac7x.out & lac7xf.out & lac7xt.out \\
\hline 11 & $\mathrm{CH}$ & Yes & lac11.out & lac11xf.out & lac11xt.out \\
\hline 11 & $\overline{\mathrm{CH}}$ & Yes & lac11x.out & laclf.out & lac1t.out \\
\hline
\end{tabular}




\begin{tabular}{|l|l|l|l|l|l|}
\hline \multicolumn{2}{|c|}{ Treatment Case } & \multicolumn{1}{c|}{ Standard } & To Calculation & From Calculation \\
\hline Sites & Hand & alpha & & \multicolumn{2}{|c|}{ File Names } \\
\hline 50 & CH & Yes & lac50.out & lac50f.out & lac50t.out \\
\hline 50 & CH & Yes & lac50x.out & lac50xf.out & lac50xt.out \\
\hline 1 & RH & --- & lr1.out & lr11f.out & lr11t.out \\
\hline 4 & RH & --- & lr4.out & Ir4f.out & Ir4t.out \\
\hline 7 & RH & --- & lr7.out & lr7f.out & lr7t.out \\
\hline 11 & RH & --- & Ir11.out & Ir1f.out & lr1t.out \\
\hline 50 & RH & --- & Ir50.out & lr50f.out & lr50t.out \\
\hline
\end{tabular}

\section{2. $\quad$ Mixed TRU and TRU}

For the mixed TRU and TRU analysis, the rollup of the cases was done for all (16) sites, for 5 sites, for 3 sites, and for 1 site. The three treatment systems for each of these are:

1. treat to LDR disposal standards,

2. treat for reduced gas, and

3. treat for WIPP Waste Acceptance Criteria.

Furthermore, the remote-handled waste was processed separately from the contact-handled waste. Table 5.2.1 contains the file names for the TRU and MTRU unit process operations. The waste type, TRU or MTRU is indicated by the $M$ in front of the file. The number of sites is given by the digits following the TRU, and the case is given by the last letter: W for WIPP WAC, R for RCRA Compliant, and G for Reduced Gas WIPP WAC. For the remote handled wastes, there are only 3 cases, the 2 site, the 4 site and the 5 site. For these, only the 2 site RCRA and reduced gas cases were analyzed along with the treatment process rates. For the 4-site case, the RCRA and reduced gas cases were analyzed, and for the 5-site case, only the WIPP WAC case was analyzed.

Table 5.2.1 - TRU and MTRU Treatment Files

\begin{tabular}{|l|l|l|l|l|}
\hline \multicolumn{5}{|c|}{ Treatment Cases/Reports } \\
\hline WIPP WAC & $\begin{array}{c}\text { RCRA } \\
\text { Compliant }\end{array}$ & $\begin{array}{c}\text { Reduced Gas } \\
\text { WIPP WAC }\end{array}$ & $\begin{array}{c}\text { Remote } \\
\text { Handled }\end{array}$ & $\begin{array}{c}\text { Treatment Process } \\
\text { Rates }\end{array}$ \\
\hline MTRU1W.out & MTRU1R.out & MTRU1G.out & TRURH2R.out & MTRU1TPR.TXT \\
\hline MTRU3W.out & MTRU3R.out & MTRU3G.out & TRURH2G.out & MTRU3TPR.TXT \\
\hline MTRU5W.out & MTRU5R.out & MTRU5G.out & RH2TPR.txt & MTRU5TPR.TXT \\
\hline MTRU16W.out & MTRU16R.out & MTRU16G.out & RH4R.out & MTRU16TPR.TXT \\
\hline TRU1W.out & TRU1R.out & TRU1G.out & TRURH4G.out & TRU1TPR.TXT \\
\hline TRU3W.out & TRU3R.out & TRU3G.out & RH4TPR.txt & TRU3TPR.TXT \\
\hline TRU5W.out & TRU5R.out & TRU5G.out & RH5W.out & TRU5TPR.TXT \\
\hline TRU16W.out & TRU16R.out & TRU16G.out & RH5tpr.txt & TRU16TPR.TXT \\
\hline
\end{tabular}


An example of the file format for these cases is shown in Table 5.2.2. The first column gives the matrix input based on the IMWIR matrices, as named in the second column. The third column gives the treatment volume in cubic meters. The final form numbers that appear in these files are below 100. In this particular example the treatment site is Idaho National Engineering Laboratory, and the case is the Mixed TRU, a 3-site case, that was contact handled.

Table 5.2.2 - TRU and MTRU Treatment File Example

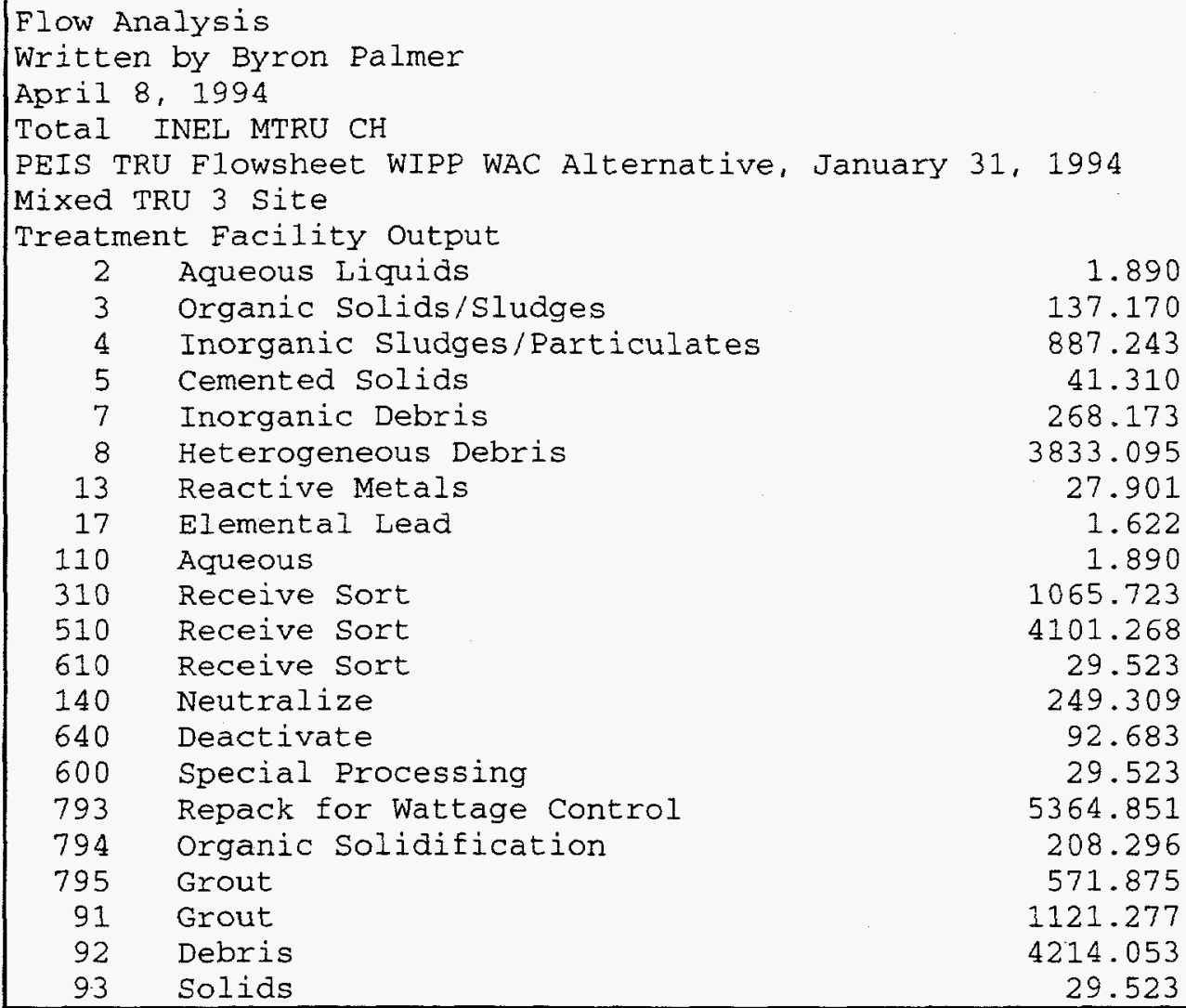

The Table 5.2.3 is an example of the treatment process rates file for the TRU and MTRU files. This is a complex file, for each of the waste matrices it provides, the number of waste streams (\# column) and the amount of waste to be treated for each of the following categories: NEUTR (neutralization of acid and basic wastes), ORDST (organic destruction), WWTOR (organic destruction in water), METRM (metal removal), DECON (decontamination), DEACT (deactivation), METRC (metal recovery), and STABL (stabilization). These categories were used in some of the risk calculations for treatment units, especially before the full modeling of the treatment system described above. The format of Table 5.2.3 has been altered so that a single line of the file spans two lines of the table. 
Table 5.2.3 - TRU and MTRU Treatment Process Rates Example

\begin{tabular}{|c|c|c|c|c|c|c|c|c|}
\hline$\#$ & $\begin{array}{l}3 \text { site } \\
\text { WWTOR }\end{array}$ & $\begin{array}{l}\text { Handl } \\
\text { METRM }\end{array}$ & $\begin{array}{l}\text { Flow } \\
\text { DECON }\end{array}$ & $\begin{array}{l}\text { Matrix } \\
\text { DEACT }\end{array}$ & $\begin{array}{l}\text { SiteID } \\
\text { METRC }\end{array}$ & $\begin{array}{l}\text { HGSEP } \\
\text { STABL }\end{array}$ & $\begin{array}{l}\text { NEUTR } \\
\text { Total }\end{array}$ & ORDST \\
\hline 1 & 0 & 1.89 & 0 & 0 & $\begin{array}{l}\text { RF } \\
0 \\
\end{array}$ & $\begin{array}{l}0 \\
1.8 \\
\end{array}$ & $\begin{array}{l}0 \\
1.8 \\
\end{array}$ & 0 \\
\hline 1 & 0 & 1.89 & 0 & $\begin{array}{l}2 \\
0 \\
\end{array}$ & 0 & $\begin{array}{l}0 \\
1.8 \\
\end{array}$ & $\begin{array}{l}0 \\
1.8 \\
\end{array}$ & 0 \\
\hline 1 & 0 & 1.89 & $\begin{array}{l}1000 \\
0\end{array}$ & 0 & 0 & $\begin{array}{l}0 \\
1.8 \\
\end{array}$ & $\begin{array}{l}0 \\
1.8 \\
\end{array}$ & 0 \\
\hline 2 & 0 & 0 & 0 & 0 & $\begin{array}{l}\text { IN } \\
0\end{array}$ & $\begin{array}{l}0 \\
79.2 \\
\end{array}$ & $\begin{array}{l}0 \\
137.1 \\
\end{array}$ & 137.1 \\
\hline 2 & 0 & 0 & 0 & $\begin{array}{l}3 \\
0\end{array}$ & 0 & $\begin{array}{l}0 \\
79.2\end{array}$ & $\begin{array}{l}0 \\
137.1 \\
\end{array}$ & 137.1 \\
\hline 4 & 0 & 0 & 0 & 0 & $\begin{array}{l}\text { IN } \\
0\end{array}$ & $\begin{array}{l}496.9 \\
510.8 \\
\end{array}$ & $\begin{array}{l}0 \\
511.7 \\
\end{array}$ & 511.7 \\
\hline 2 & 0 & 0 & 0 & 0 & $\begin{array}{l}\text { LA } \\
0 \\
\end{array}$ & $\begin{array}{l}0 \\
320.5 \\
\end{array}$ & $\begin{array}{l}0 \\
320.5 \\
\end{array}$ & 320.5 \\
\hline 8 & 0 & 0 & 0 & 0 & $\begin{array}{l}\text { RF } \\
0 \\
\end{array}$ & $\begin{array}{l}23.4 \\
54.9 \\
\end{array}$ & $\begin{array}{l}0 \\
54.9 \\
\end{array}$ & 44.8 \\
\hline 14 & 0 & 0 & 0 & $\begin{array}{l}4 \\
0\end{array}$ & 0 & $\begin{array}{l}520.3 \\
886.3\end{array}$ & $\begin{array}{l}0 \\
887.2\end{array}$ & 877.1 \\
\hline 1 & 0 & 0 & 0 & 0 & $\begin{array}{l}\text { LA } \\
0 \\
\end{array}$ & $\begin{array}{l}0 \\
11.73 \\
\end{array}$ & $\begin{array}{l}0 \\
11.73 \\
\end{array}$ & 0 \\
\hline 2 & 0 & 0 & 0 & 0 & $\begin{array}{l}\mathrm{RF} \\
0 \\
\end{array}$ & $\begin{array}{l}0 \\
10.65 \\
\end{array}$ & $\begin{array}{l}0 \\
29.58 \\
\end{array}$ & 18.9 \\
\hline 3 & 0 & 0 & 0 & $\begin{array}{l}5 \\
0 \\
\end{array}$ & 0 & $\begin{array}{l}0 \\
22.38 \\
\end{array}$ & $\begin{array}{l}0 \\
41.31 \\
\end{array}$ & 18.9 \\
\hline 19 & 0 & 0 & $\begin{array}{l}3000 \\
0\end{array}$ & 0 & 0 & $\begin{array}{l}520.3 \\
987.9 \\
\end{array}$ & $\begin{array}{l}0 \\
1065.7 \\
\end{array}$ & 1033 \\
\hline 3 & 0 & 0 & 13 & 0 & $\begin{array}{l}\text { IN } \\
0 \\
\end{array}$ & $\begin{array}{l}101.4 \\
114.4 \\
\end{array}$ & $\begin{array}{l}0 \\
114.4 \\
\end{array}$ & 114.4 \\
\hline 10 & 0 & 0 & 153.7 & 0 & $\begin{array}{l}R F \\
0 \\
\end{array}$ & $\begin{array}{l}2.5 \\
153.7 \\
\end{array}$ & $\begin{array}{l}0 \\
153.7 \\
\end{array}$ & 137.2 \\
\hline 13 & 0 & 0 & 166.7 & $\begin{array}{l}7 \\
0\end{array}$ & 0 & $\begin{array}{l}103.9 \\
268.1\end{array}$ & $\begin{array}{l}0 \\
268.1\end{array}$ & 251.6 \\
\hline 8 & 0 & 0 & 1173.7 & 0 & $\begin{array}{l}\text { IN } \\
0\end{array}$ & $\begin{array}{l}1872.3 \\
3046.1 \\
\end{array}$ & $\begin{array}{l}0 \\
3046.1 \\
\end{array}$ & 3046 . \\
\hline 7 & 0 & 0 & 725.64 & 0 & $\begin{array}{l}\text { LA } \\
0\end{array}$ & $\begin{array}{l}0 \\
725.64\end{array}$ & $\begin{array}{l}0 \\
725.64\end{array}$ & 373.1 \\
\hline 1 & 0 & 0 & 61.2 & 0 & $\begin{array}{l}\text { NT } \\
0\end{array}$ & $\begin{array}{l}0 \\
61.2 \\
\end{array}$ & $\begin{array}{l}0 \\
61.2 \\
\end{array}$ & 61.2 \\
\hline 1 & 0 & 0 & 0.095 & 0 & $\begin{array}{l}\text { SA } \\
0 \\
\end{array}$ & $\begin{array}{l}0 \\
0.095 \\
\end{array}$ & $\begin{array}{l}0 \\
0.095 \\
\end{array}$ & 0 \\
\hline 17 & 0 & 0 & 1960.7 & $\begin{array}{l}8 \\
0 \\
\end{array}$ & 0 & $\begin{array}{l}1872.3 \\
3833.0 \\
\end{array}$ & $\begin{array}{l}0 \\
3833.0 \\
\end{array}$ & 3480 . \\
\hline 30 & 0 & 2127.4 & $\begin{array}{l}5000 \\
0 \\
\end{array}$ & 0 & 4101.2 & $\begin{array}{l}1976.3 \\
4101.2 \\
\end{array}$ & 3732.2 & 0 \\
\hline 1 & 0 & 0 & 0 & 12.25 & $\begin{array}{l}\text { LA } \\
0\end{array}$ & $\begin{array}{l}0 \\
0\end{array}$ & $\begin{array}{l}0 \\
12.25\end{array}$ & 0 \\
\hline 2 & 0 & 0 & 0 & 0.021 & $\begin{array}{l}\mathrm{RF} \\
0\end{array}$ & $\begin{array}{l}0 \\
0\end{array}$ & $\begin{array}{l}0 \\
15.651\end{array}$ & 0 \\
\hline
\end{tabular}




\begin{tabular}{|c|c|c|c|c|c|c|c|c|}
\hline 3 & 0 & 0 & 0 & $\begin{array}{l}13 \\
12.271 \\
\end{array}$ & 0 & $\begin{array}{l}0 \\
0 \\
\end{array}$ & $\begin{array}{l}0 \\
27.901 \\
\end{array}$ & 0 \\
\hline 3 & 0 & 0 & $\begin{array}{l}6000 \\
0 \\
\end{array}$ & 12.271 & 0 & $\begin{array}{l}0 \\
0 \\
\end{array}$ & $\begin{array}{l}0 \\
27.901 \\
\end{array}$ & 0 \\
\hline 1 & 0 & 0 & 0 & 0 & $\begin{array}{l}\text { ET } \\
0.002\end{array}$ & $\begin{array}{l}0 \\
0.002\end{array}$ & $\begin{array}{l}0 \\
0.002\end{array}$ & 0 \\
\hline 1 & 0 & 0 & 0 & 0 & $\begin{array}{l}\mathrm{RF} \\
1.6 \\
\end{array}$ & $\begin{array}{l}0 \\
1.6 \\
\end{array}$ & $\begin{array}{l}0 \\
1.62 \\
\end{array}$ & 0 \\
\hline 2 & 0 & 0 & 0 & $\begin{array}{l}17 \\
0 \\
\end{array}$ & 1.6 & $\begin{array}{l}0 \\
1.6 \\
\end{array}$ & $\begin{array}{l}0 \\
1.6 \\
\end{array}$ & 0 \\
\hline 2 & 0 & 0 & $\begin{array}{l}7000 \\
0 \\
\end{array}$ & 0 & 1.6 & $\begin{array}{l}0 \\
1.6 \\
\end{array}$ & $\begin{array}{l}0 \\
1.6 \\
\end{array}$ & 0 \\
\hline 55 & $\begin{array}{l}\text { IN } \\
0\end{array}$ & 1.89 & 2127.4 & 12.2 & 1.6 & $\begin{array}{l}2496.72 \\
5092.6\end{array}$ & $\begin{array}{l}0 \\
5198.4\end{array}$ & 4765 . \\
\hline
\end{tabular}

\section{Conclusion}

This report documents the changes, the corrections, and the analysis of the mixed waste for the Programmatic Environmental Impact Statement. Individual details of each treatment unit's operation is contained elsewhere. The full results are available on the internet or on disk as needed. 


\section{Appendix A-EPA Codes/Contaminants}

\section{Table A - EPA Codes and Contaminant Codes}

\begin{tabular}{|l|l|}
\hline EPA Code & Contaminant Code \\
\hline 141 & Not Assigned \\
\hline 171 & Not Assigned \\
\hline 172 & Not Assigned \\
\hline 181 & Not Assigned \\
\hline 221 & Not Assigned \\
\hline 261 & Not Assigned \\
\hline 352 & Not Assigned \\
\hline 461 & Not Assigned \\
\hline 551 & Not Assigned \\
\hline 791 & Not Assigned \\
\hline 792 & Not Assigned \\
\hline B001 & OF \\
\hline B002 & OF \\
\hline B003 & OF \\
\hline B004 & OF \\
\hline B005 & OF \\
\hline B007 & OF \\
\hline CA 551 & Not Assigned \\
\hline CA134 & OF \\
\hline CA181 & M \\
\hline CA221 & O \\
\hline CA352 & O \\
\hline D001 & I \\
\hline D001A & I \\
\hline D001B & I \\
\hline D001C & S \\
\hline D001E & I \\
\hline D001X & I \\
\hline D002 & C \\
\hline D002A & S \\
\hline D002B & C \\
\hline D002C & S \\
\hline D003 & A \\
\hline D003A & A \\
\hline D003B & A \\
\hline D003C & E \\
\hline D003D & W \\
\hline D003E & R \\
\hline D004 & M \\
\hline D004A & M \\
\hline D004B & M \\
\hline D005 & M \\
\hline D005A & M \\
\hline D005B & M \\
\hline D006 & M \\
\hline & \\
\hline
\end{tabular}

\begin{tabular}{|l|l|}
\hline EPA Code & Contaminant Code \\
\hline D006A & M \\
\hline D006B & M \\
\hline D006C & M \\
\hline D007 & M \\
\hline D007A & M \\
\hline D007B & M \\
\hline D008 & M \\
\hline D008A & M \\
\hline D008B & M \\
\hline D008C & M \\
\hline D008D & M \\
\hline D009 & MH \\
\hline D009A & MH \\
\hline D009B & MH \\
\hline D009C & MH \\
\hline D009D & MH \\
\hline D009E & MH \\
\hline D009F & MH \\
\hline D009X & MH \\
\hline D010 & M \\
\hline D010A & M \\
\hline D010B & M \\
\hline D011 & M \\
\hline D011A & M \\
\hline D011B & M \\
\hline D012 & OF \\
\hline D013 & OF \\
\hline D014 & OF \\
\hline D015 & OF \\
\hline D016 & OF \\
\hline D017 & OF \\
\hline D018 & O \\
\hline D018A & O \\
\hline D019 & OF \\
\hline D020 & OF \\
\hline D021 & OF \\
\hline D022 & OF \\
\hline D023 & O \\
\hline D024 & O \\
\hline D025 & O \\
\hline D026 & O \\
\hline D027 & OF \\
\hline D028 & OF \\
\hline D029 & OF \\
\hline D030 & O \\
\hline & \\
\hline
\end{tabular}




\begin{tabular}{|c|c|c|c|}
\hline EPA Code & Contaminant Code & \begin{tabular}{|l} 
EPA Code \\
\end{tabular} & Contaminant Code \\
\hline D031 & & & \\
\hline $\mathrm{D} 032$ & $\mathrm{OF}$ & FOMX & OMHF \\
\hline $\mathrm{D} 033$ & $\mathrm{OF}$ & FXXX & $\mathrm{OMF}$ \\
\hline $\mathrm{D} 034$ & $\mathrm{OF}$ & K001 & $\mathrm{OF}$ \\
\hline D035 & 0 & K002 & $\bar{M}$ \\
\hline $\mathrm{D} 036$ & $\mathrm{O}$ & $\mathrm{K} 003$ & $\bar{M}$ \\
\hline $\mathrm{D} 037$ & $\mathrm{OF}$ & K004 & $\mathrm{M}$ \\
\hline D038 & 0 & K005 & $\bar{M}$ \\
\hline D039 & $\mathrm{OF}$ & K006A & $\overline{\mathrm{M}}$ \\
\hline $\mathrm{D} 040$ & $\mathrm{OF}$ & K006B & $\bar{M}$ \\
\hline $\mathrm{D} 041$ & $\mathrm{OF}$ & K007 & $\bar{M}$ \\
\hline$\overline{\mathrm{D} 042}$ & $\mathrm{OF}$ & K008 & $\bar{M}$ \\
\hline D043 & $\mathrm{OF}$ & K009 & $\mathrm{O}$ \\
\hline D044 & $\mathrm{OM}$ & $\mathrm{K} 010$ & $\mathrm{O}$ \\
\hline DOMX & $\mathrm{OM}$ & K011 & $\overline{\mathrm{O}}$ \\
\hline DXXX & $\mathrm{OM}$ & $\mathrm{K} 013$ & $\mathrm{O}$ \\
\hline F001 & $\mathrm{OF}$ & K014 & 0 \\
\hline F002 & $\mathrm{OF}$ & $\mathrm{K} 015$ & $\mathrm{OF}$ \\
\hline F003 & $\mathrm{OF}$ & $\mathrm{K} 016$ & $\mathrm{OF}$ \\
\hline F004 & $\mathrm{O}$ & K017 & $\mathrm{OF}$ \\
\hline F005 & $\mathrm{O}$ & K044 & $\mathrm{O}$ \\
\hline F005A & $\mathrm{O}$ & K045 & $\bar{O}$ \\
\hline F005B & $\mathrm{O}$ & K069A & $\bar{M}$ \\
\hline F005C & $\mathrm{O}$ & K069B & $\mathrm{M}$ \\
\hline F005X & $\mathrm{O}$ & NA & $\mathrm{OF}$ \\
\hline F006 & $\mathrm{M}$ & $\mathrm{NC}$ & $\mathrm{OF}$ \\
\hline F007 & $\mathrm{A}$ & P004 & $\mathrm{OF}$ \\
\hline F008 & $\mathrm{A}$ & P005 & $\mathrm{O}$ \\
\hline F009 & $\mathrm{A}$ & P009 & Not Assigned \\
\hline Fo10 & $\mathrm{OA}$ & P010 & $\mathrm{M}$ \\
\hline F011 & $\mathrm{A}$ & P011 & $\mathrm{M}$ \\
\hline F012 & $\mathrm{A}$ & \begin{tabular}{|l}
$\mathrm{P} 012$ \\
\end{tabular} & $\bar{M}$ \\
\hline F019 & $\mathrm{M}$ & P014 & $\mathrm{O}$ \\
\hline F020 & $\mathrm{OF}$ & $\mathrm{P} 015$ & $\mathrm{M}$ \\
\hline F021 & $\mathrm{OF}$ & $\mathrm{P} 016$ & $\mathrm{OF}$ \\
\hline F022 & $\mathrm{OF}$ & \begin{tabular}{|l|l}
$\mathrm{P} 017$ \\
\end{tabular} & $\mathrm{OF}$ \\
\hline F023 & $\mathrm{OF}$ & \begin{tabular}{|l|l|}
$\mathrm{P} 018$ \\
\end{tabular} & $\mathrm{O}$ \\
\hline F024 & $\mathrm{OF}$ & \begin{tabular}{|l|l}
$\mathrm{P} 022$ \\
\end{tabular} & $\mathrm{O}$ \\
\hline F025A & $\mathrm{OF}$ & $\mathrm{P} 023$ & $\mathrm{OF}$ \\
\hline F025B & $\mathrm{OF}$ & \begin{tabular}{|l}
$\mathrm{P} 024$ \\
\end{tabular} & $\mathrm{OF}$ \\
\hline F026 & $\mathrm{OF}$ & P027 & $\mathrm{OF}$ \\
\hline F027 & $\mathrm{OF}$ & \begin{tabular}{|l|l|} 
P028 \\
\end{tabular} & $\mathrm{OF}$ \\
\hline F028 & $\mathrm{OF}$ & \begin{tabular}{|l}
$\mathrm{P} 029$ \\
\end{tabular} & MA \\
\hline $\mathrm{F} 032$ & $\mathrm{OF}$ & \begin{tabular}{|l|l|}
$\mathrm{P} 030$ \\
\end{tabular} & $\mathrm{OA}$ \\
\hline F034 & $\mathrm{O}$ & \begin{tabular}{|l|}
$\mathrm{P} 031$ \\
\end{tabular} & $\mathrm{O}$ \\
\hline F035 & \begin{tabular}{|l}
$\mathrm{M}$ \\
\end{tabular} & $\begin{array}{l}\text { P034 } \\
\end{array}$ & $\mathrm{OM}$ \\
\hline \begin{tabular}{|l}
$\mathrm{F} 037$ \\
\end{tabular} & 0 & \begin{tabular}{|l|} 
P037 \\
\end{tabular} & $\mathrm{OF}$ \\
\hline \begin{tabular}{|l} 
Fo38 \\
\end{tabular} & \begin{tabular}{|l|}
0 \\
\end{tabular} & \begin{tabular}{|l|} 
P045 \\
\end{tabular} & 0 \\
\hline
\end{tabular}




\begin{tabular}{|l|l|}
\hline EPA Code & Contaminant Code \\
\hline P046 & O \\
\hline P047 & O \\
\hline P048 & O \\
\hline P049 & O \\
\hline P050 & OF \\
\hline P051 & OF \\
\hline P054 & Not Assigned \\
\hline P056 & OF \\
\hline P059 & OF \\
\hline P060 & OF \\
\hline P063 & A \\
\hline P064 & OA \\
\hline P065A & H \\
\hline P065B & H \\
\hline P065C & H \\
\hline P065D & H \\
\hline P066 & O \\
\hline P067 & O \\
\hline P068 & O \\
\hline P069 & O \\
\hline P070 & O \\
\hline P071 & O \\
\hline P072 & O \\
\hline P073 & MA \\
\hline P074 & MA \\
\hline P075 & O \\
\hline P077 & O \\
\hline P081 & Not Assigned \\
\hline P087 & M \\
\hline P088 & O \\
\hline P089 & O \\
\hline P092A & OH \\
\hline P092B & H \\
\hline P092C & OH \\
\hline P092D & OH \\
\hline P093 & O \\
\hline P094 & O \\
\hline P095 & F \\
\hline P098 & A \\
\hline P102 & O \\
\hline P104 & MA \\
\hline P105 & Not Assigned \\
\hline P106 & A \\
\hline P108 & O \\
\hline P112 & Not Assigned \\
\hline P113 & M \\
\hline P116 & O \\
\hline P119 & M \\
\hline & \\
\hline
\end{tabular}

\begin{tabular}{|l|l|}
\hline EPA Code & Contaminant Code \\
\hline P120 & M \\
\hline P121 & A \\
\hline P122 & M \\
\hline P123 & OF \\
\hline PCB & OF \\
\hline POMX & OMHF \\
\hline PXxx & OMHF \\
\hline TSCA & OF \\
\hline U001 & O \\
\hline U002 & O \\
\hline U003 & O \\
\hline U004 & O \\
\hline U005 & O \\
\hline U006 & OF \\
\hline U007 & O \\
\hline U008 & O \\
\hline U009 & O \\
\hline U010 & O \\
\hline U011 & O \\
\hline U012 & O \\
\hline U014 & O \\
\hline U017 & OF \\
\hline U018 & O \\
\hline U019 & O \\
\hline U020 & OF \\
\hline U021 & O \\
\hline U022 & O \\
\hline U023 & OF \\
\hline U024 & OF \\
\hline U025 & OF \\
\hline U026 & OF \\
\hline U027 & OF \\
\hline U028 & O \\
\hline U029 & OF \\
\hline U030 & OF \\
\hline U031 & O \\
\hline U032 & M \\
\hline U033 & OF \\
\hline O034 & OF \\
\hline U035 & OF \\
\hline U036 & OF \\
\hline U037 & OF \\
\hline U038 & OF \\
\hline U039 & OF \\
\hline U041 & OF \\
\hline O002 & OF \\
\hline U043 & OF \\
\hline U044 & OF \\
\hline & \\
\hline
\end{tabular}




\begin{tabular}{|c|c|c|c|}
\hline EPA Code & Contaminant Code & EPA Code & Contaminant Code \\
\hline U045 & $\mathrm{OF}$ & U095 & o \\
\hline U046 & $\mathrm{OF}$ & $\begin{array}{ll}\text { U101 } \\
\end{array}$ & $\mathrm{O}$ \\
\hline 0047 & $\mathrm{OF}$ & 0102 & $\overline{0}$ \\
\hline U048 & $\mathrm{OF}$ & U103 & $\mathrm{O}$ \\
\hline U049 & $\mathrm{OF}$ & U105 & $\mathrm{O}$ \\
\hline U050 & $\overline{0}$ & U106 & $\mathrm{O}$ \\
\hline U051 & $\mathrm{O}$ & U107 & $\mathrm{O}$ \\
\hline $\mathrm{U} 052$ & $\mathrm{O}$ & \begin{tabular}{|l|l} 
U108 \\
\end{tabular} & 0 \\
\hline U053 & $\mathrm{O}$ & \begin{tabular}{|l}
$\mathrm{U} 109$ \\
\end{tabular} & $\mathrm{O}$ \\
\hline U055 & $\mathrm{O}$ & U110 & 0 \\
\hline U056 & $\mathrm{O}$ & U111 & $\mathrm{O}$ \\
\hline $\bar{U} 057$ & $O$ & $\overline{\text { U112 }}$ & $\mathrm{O}$ \\
\hline U058 & $\mathrm{OF}$ & U113 & $\mathrm{O}$ \\
\hline U059 & $\mathrm{O}$ & U114 & 0 \\
\hline U060 & OF & U115 & 0 \\
\hline U061 & $\mathrm{OF}$ & U116 & $\mathrm{O}$ \\
\hline U062 & $\mathrm{OF}$ & \begin{tabular}{|l|l|l} 
U117 \\
\end{tabular} & $\mathrm{O}$ \\
\hline 0063 & $\mathrm{O}$ & U118 & $\mathrm{O}$ \\
\hline U064 & $\mathrm{O}$ & \begin{tabular}{|l} 
U119 \\
\end{tabular} & $\mathrm{O}$ \\
\hline U066 & $\mathrm{OF}$ & U120 & $\mathrm{O}$ \\
\hline U067 & $\mathrm{OF}$ & U121 & $\mathrm{OF}$ \\
\hline U068 & $\mathrm{OF}$ & \begin{tabular}{|l|l|} 
U122 \\
\end{tabular} & 0 \\
\hline U069 & $\mathrm{O}$ & \begin{tabular}{|l} 
U123 \\
\end{tabular} & 0 \\
\hline U070 & $\mathrm{OF}$ & U124 & $\mathrm{O}$ \\
\hline U071 & $\mathrm{OF}$ & U125 & 10 \\
\hline U072 & $\mathrm{OF}$ & \begin{tabular}{|l|l} 
U12 \\
\end{tabular} & 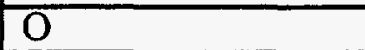 \\
\hline U073 & $\mathrm{OF}$ & \begin{tabular}{|l|l} 
U127 \\
\end{tabular} & OF \\
\hline U074 & $\mathrm{OF}$ & \begin{tabular}{|l|l|}
$\mathrm{U} 128$ \\
\end{tabular} & $\mathrm{OF}$ \\
\hline U075 & $\mathrm{OF}$ & \begin{tabular}{|l|} 
U129 \\
\end{tabular} & $\mathrm{OF}$ \\
\hline U076 & $\mathrm{OF}$ & U130 & $\mathrm{OF}$ \\
\hline U077 & \begin{tabular}{|l|}
$\mathrm{OF}$ \\
\end{tabular} & \begin{tabular}{|l} 
U131 \\
\end{tabular} & \begin{tabular}{|l}
$\mathrm{OF}$ \\
\end{tabular} \\
\hline U078 & $\mathrm{OF}$ & U132 & $\mathrm{OF}$ \\
\hline U079 & $\mathrm{OF}$ & \begin{tabular}{|l|l} 
U133 \\
\end{tabular} & Not Assigned \\
\hline U080 & $\mathrm{OF}$ & 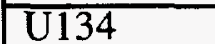 & $\mathrm{F}$ \\
\hline $\mathrm{U} 081$ & $\mathrm{OF}$ & \begin{tabular}{|l} 
U135 \\
\end{tabular} & $\mathrm{A}$ \\
\hline U082 & $\mathrm{OF}$ & \begin{tabular}{|l} 
U136 \\
\end{tabular} & $\mathrm{OM}$ \\
\hline \begin{tabular}{|l} 
U083 \\
\end{tabular} & $\mathrm{OF}$ & \begin{tabular}{|l|l|} 
U137 \\
\end{tabular} & $\mathrm{O}$ \\
\hline U084 & $\mathrm{OF}$ & \begin{tabular}{|l} 
U138 \\
\end{tabular} & $\mathrm{OF}$ \\
\hline \begin{tabular}{|l}
085 \\
\end{tabular} & 0 & \begin{tabular}{|l} 
U140 \\
\end{tabular} & 0 \\
\hline U086 & 0 & \begin{tabular}{|l|l} 
U141 \\
\end{tabular} & $\mathrm{O}$ \\
\hline U087 & 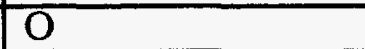 & U142 & $\mathrm{OF}$ \\
\hline U088 & 0 & 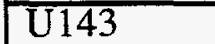 & 10 \\
\hline U089 & 10 & \begin{tabular}{|l|} 
U144 \\
\end{tabular} & $O M$ \\
\hline U090 & 0 & \begin{tabular}{|l|l} 
U145 \\
\end{tabular} & $\mathrm{M}$ \\
\hline \begin{tabular}{|l|l|} 
U091 \\
\end{tabular} & $\mathrm{O}$ & \begin{tabular}{|l|} 
U146 \\
\end{tabular} & $\mathrm{OM}$ \\
\hline \begin{tabular}{|l|l} 
U092 \\
\end{tabular} & 0 & \begin{tabular}{|l|} 
U147 \\
\end{tabular} & 0 \\
\hline \begin{tabular}{|l|} 
U093 \\
\end{tabular} & 0 & \begin{tabular}{|l|l} 
U148 \\
\end{tabular} & $\mathrm{O}$ \\
\hline U094 & o & U149 & 0 \\
\hline
\end{tabular}




\begin{tabular}{|l|l|}
\hline EPA Code & Contaminant Code \\
\hline U150 & OF \\
\hline U151 & H \\
\hline U151A & H \\
\hline U151B & H \\
\hline U151C & H \\
\hline U151D & H \\
\hline U151X & H \\
\hline U152 & O \\
\hline U153 & O \\
\hline U154 & O \\
\hline U155 & O \\
\hline U156 & OF \\
\hline U157 & O \\
\hline U158 & OF \\
\hline U159 & O \\
\hline U160 & O \\
\hline U161 & O \\
\hline U162 & O \\
\hline U163 & O \\
\hline U164 & O \\
\hline U165 & O \\
\hline U166 & O \\
\hline U167 & O \\
\hline U168 & O \\
\hline U169 & O \\
\hline U170 & O \\
\hline U171 & O \\
\hline U172 & O \\
\hline U173 & O \\
\hline U174 & O \\
\hline U176 & O \\
\hline U177 & O \\
\hline U182 & O \\
\hline U183 & OF \\
\hline U184 & OF \\
\hline U185 & OF \\
\hline U186 & O \\
\hline U187 & O \\
\hline U188 & O \\
\hline U189 & Not Assigned \\
\hline U190 & O \\
\hline U191 & O \\
\hline U194 & O \\
\hline U196 & O \\
\hline U197 & O \\
\hline U201 & O \\
\hline U202 & O \\
\hline U204 & M \\
\hline & \\
\hline
\end{tabular}

\begin{tabular}{|l|l|}
\hline EPA Code & Contaminant Code \\
\hline U205 & MA \\
\hline U207 & OF \\
\hline U208 & OF \\
\hline U209 & OF \\
\hline U210 & OF \\
\hline U211 & OF \\
\hline U213 & O \\
\hline U214 & OM \\
\hline U215 & OM \\
\hline U216 & MF \\
\hline U217 & MF \\
\hline U218 & O \\
\hline U219 & O \\
\hline U220 & O \\
\hline U221 & O \\
\hline U222 & OF \\
\hline U223 & O \\
\hline U225 & OF \\
\hline U226 & OF \\
\hline U227 & OF \\
\hline U228 & OF \\
\hline U234 & O \\
\hline U235 & OF \\
\hline U236 & O \\
\hline U237 & O \\
\hline U238 & O \\
\hline U239 & O \\
\hline U240 & OF \\
\hline U246 & OAF \\
\hline U247 & OF \\
\hline U248 & O \\
\hline U328 & O \\
\hline U359 & O \\
\hline UNK & OF \\
\hline UOMX & OMF \\
\hline Uxxx & OMF \\
\hline W001 & Not Assigned \\
\hline WC01 & Not Assigned \\
\hline WC02 & Not Assigned \\
\hline WL01 & Not Assigned \\
\hline WL02 & Not Assigned \\
\hline WP01 & Not Assigned \\
\hline WP02 & Not Assigned \\
\hline WP03 & Not Assigned \\
\hline WT01 & Not Assigned \\
\hline WT02 & Not Assigned \\
\hline WTL2 & OF \\
\hline & \\
\hline
\end{tabular}




\section{Appendix B-Site/Case Assignments}

Table B. 1 gives the site shipment for each of the cases, and site appreviations follow in

Table B.2. The type of waste by CH (contact handled), RH (remote handled), alpha (waste with the alpha characteristic), MLLW (mixed low-level waste) and MTRU (mixed TRU waste).

Table B.1-Site Shipment Assignments

\begin{tabular}{|c|c|c|c|c|c|c|}
\hline Site & Type & 50 & 11 & 7 & 5 & 4 \\
\hline$\overline{\mathrm{AE}}$ & MLLW CH & $\overline{\mathrm{AE}}$ & $\overline{\mathrm{FM}}$ & $\overline{\mathrm{PO}}$ & $\overline{\mathrm{OR}}$ & OR \\
\hline$\overline{\mathrm{AE}}$ & MTRU & $\mathrm{AE}$ & $\overline{S R}$ & SR & $\overline{S R}$ & $\overline{S R}$ \\
\hline$\overline{\mathrm{AL}}$ & MLLW CH & $\overline{\mathrm{AL}}$ & $\overline{F M}$ & $\overline{\mathrm{PO}}$ & $\mathrm{RF}$ & $\overline{O R}$ \\
\hline$\overline{\mathrm{AL}}$ & MTRU & $\overline{\mathrm{AL}}$ & SR & SR & $\overline{\mathrm{SR}}$ & SR \\
\hline$\overline{\mathrm{AW}}$ & MLLW CH & IN & IN & IN & IN & IN \\
\hline$\overline{A W}$ & MLLW RH & IN & IN & $\overline{\mathrm{IN}}$ & IN & IN \\
\hline $\mathrm{AW}$ & MTRU & IN & IN & $\overline{\mathrm{IN}}$ & IN & IN \\
\hline$\overline{\mathrm{BC}}$ & MLLW CH & $\overline{\mathrm{BC}}$ & $\overline{\mathrm{PO}}$ & $\overline{\mathrm{PO}}$ & $\overline{\mathrm{OR}}$ & $\overline{\mathrm{OR}}$ \\
\hline$\overline{\mathrm{BN}}$ & MLLW CH & $\overline{\mathrm{BN}}$ & $\overline{\mathrm{PO}}$ & $\mathrm{PO}$ & $\overline{\mathrm{OR}}$ & $\overline{\mathrm{OR}}$ \\
\hline$\overline{\mathrm{BT}}$ & MLLW CH Alpha & $\overline{\mathrm{SR}}$ & $\overline{\mathrm{SR}}$ & $\mathrm{SR}$ & $\overline{\mathrm{SR}}$ & $\overline{S R}$ \\
\hline$\overline{\mathrm{BT}}$ & MLLW CH & BT & $\overline{\mathrm{PO}}$ & $\overline{\mathrm{PO}}$ & $\overline{\mathrm{OR}}$ & $\overline{\mathrm{OR}}$ \\
\hline BT & MLLW RH & $\overline{\mathrm{OR}}$ & $\overline{\mathrm{OR}}$ & $\overline{\mathrm{OR}}$ & OR & $\overline{\mathrm{OR}}$ \\
\hline$\overline{\mathrm{CI}}$ & MLLW CH & $\mathrm{CI}$ & $\overline{\mathrm{PO}}$ & $\overline{\mathrm{PO}}$ & $\overline{\mathrm{OR}}$ & $\overline{\mathrm{OR}}$ \\
\hline$\overline{\mathrm{CN}}$ & MLLW CH & $\mathrm{CN}$ & SR & SR & $\overline{\mathrm{SR}}$ & SR \\
\hline$\overline{\mathrm{DP}}$ & MLLW CH & $\overline{\mathrm{OR}}$ & $\overline{\mathrm{OR}}$ & $\mathrm{OR}$ & $\overline{\mathrm{OR}}$ & $\overline{\mathrm{OR}}$ \\
\hline$\overline{\mathrm{EH}}$ & MLLW CH & $\mathrm{EH}$ & $\overline{\mathrm{LL}}$ & RL & RL & $\overline{R L}$ \\
\hline ET & MLLW CH & ET & ET & $\overline{\mathrm{IN}}$ & $\overline{\mathrm{IN}}$ & IN \\
\hline ET & MTRU & ET & ET & $\overline{\mathrm{IN}}$ & IN & IN \\
\hline$\overline{F M}$ & MLLW CH & FM & $\overline{\text { FM }}$ & $\mathrm{PO}$ & $\overline{\mathrm{OR}}$ & $\overline{\mathrm{OR}}$ \\
\hline GA & MLLW CH & $\mathrm{GA}$ & LL & IN & IN & IN \\
\hline GJ & MLLW CH & GJ & $\overline{\mathrm{RF}}$ & $\overline{\mathrm{RF}}$ & $\overline{R F}$ & IN \\
\hline IN & MLLW CH Alpha & IN & IN & $\mathrm{IN}$ & IN & IN \\
\hline$\overline{\mathrm{IN}}$ & MLLW RH Alpha & IN & IN & $\overline{\mathrm{IN}}$ & IN & IN \\
\hline$\overline{\mathrm{IN}}$ & MLLW CH & IN & $\overline{\mathrm{IN}}$ & $\overline{I N}$ & IN & IN \\
\hline IN & MLLW RH & $\mathrm{IN}$ & IN & $\overline{\mathrm{IN}}$ & IN & IN \\
\hline IN & MTRU & IN & IN & $\overline{\mathrm{IN}}$ & IN & IN \\
\hline IT & MLLW CH Alpha & $\mathrm{LA}$ & $\overline{\mathrm{LA}}$ & $\overline{\mathrm{LA}}$ & RF & IN \\
\hline IT & MLLW CH & IT & $\overline{\mathrm{LA}}$ & $\overline{\mathrm{LA}}$ & $\overline{\mathrm{RF}}$ & IN \\
\hline$\overline{\mathrm{KA}}$ & MLLW CH & $\overline{\mathrm{KA}}$ & $\overline{\mathrm{PO}}$ & $\overline{\mathrm{PO}}$ & $\overline{\mathrm{OR}}$ & $\overline{\mathrm{OR}}$ \\
\hline$\overline{\mathrm{KA}}$ & MTRU & $\mathrm{KA}$ & SR & SR & SR & SR \\
\hline$\overline{\mathrm{KC}}$ & MLLW CH & $\overline{\mathrm{KC}}$ & $\overline{\mathrm{PA}}$ & $\mathrm{RF}$ & $\overline{\mathrm{RF}}$ & $\overline{\mathrm{OR}}$ \\
\hline$\overline{\mathrm{KK}}$ & MLLW CH & $\overline{\mathrm{KK}}$ & $\overline{\mathrm{PO}}$ & $\overline{\mathrm{PO}}$ & $\overline{\mathrm{OR}}$ & $\overline{\mathrm{OR}}$ \\
\hline $\mathrm{KW}$ & MLLW CH & $\overline{\mathrm{KW}}$ & PO & $\overline{\mathrm{PO}}$ & OR & $\overline{\mathrm{OR}}$ \\
\hline$\overline{L A}$ & MLLW CH Alpha & $\overline{\mathrm{LA}}$ & $\overline{\mathrm{LA}}$ & $\overline{\mathrm{LA}}$ & $\overline{\mathrm{RF}}$ & IN \\
\hline$\overline{\mathrm{LA}}$ & MLLW CH & $\overline{\mathrm{LA}}$ & $\overline{\mathrm{LA}}$ & $\overline{\mathrm{LA}}$ & $\overline{\mathrm{RF}}$ & $\overline{\mathrm{IN}}$ \\
\hline LA & MTRU & LA & $\overline{\mathrm{LA}}$ & LA & $\mathrm{RF}$ & IN \\
\hline$\overline{\mathrm{LB}}$ & MLLW CH Alpha & $\mathrm{LL}$ & $\mathrm{LL}$ & $\mathrm{IN}$ & $\overline{\mathrm{RL}}$ & IN \\
\hline $\mathrm{LB}$ & MLLW CH & $\overline{L B}$ & $\overline{L L}$ & RL & $\overline{\mathrm{RL}}$ & $\overline{\mathrm{RL}}$ \\
\hline$\overline{\mathrm{LL}}$ & MLLW CH Alpha & $\mathrm{LL}$ & $\overline{\mathrm{LL}}$ & $\overline{\mathrm{RL}}$ & $\overline{\mathrm{RL}}$ & $\overline{\mathrm{RL}}$ \\
\hline$\overline{\mathrm{LL}}$ & MLLW CH & $\mathrm{LL}$ & $\overline{\mathrm{LL}}$ & $\overline{\mathrm{IN}}$ & $\overline{\mathrm{RL}}$ & IN \\
\hline
\end{tabular}




\begin{tabular}{|c|c|c|c|c|c|c|}
\hline Site & Type & 50 & 11 & $\overline{7}$ & $\overline{5}$ & 4 \\
\hline$\overline{\mathrm{LL}}$ & MTRU & $\overline{L L}$ & $\overline{\mathrm{LL}}$ & $\mathrm{RL}$ & $\overline{\mathrm{RL}}$ & $\overline{R L}$ \\
\hline$\overline{\mathrm{MD}}$ & MLLW CH Alpha & $\overline{\mathrm{SR}}$ & $\overline{\text { SR }}$ & $\overline{S R}$ & SR & SR \\
\hline $\mathrm{MD}$ & MLLW CH & $\mathrm{MD}$ & FM & $\overline{\mathrm{PO}}$ & $\mathrm{OR}$ & $\overline{\mathrm{OR}}$ \\
\hline $\mathrm{MD}$ & MTRU & MD & SR & SR & $\mathrm{SR}$ & SR \\
\hline MI & $\overline{\text { MLLW CH }}$ & $\overline{\mathrm{MI}}$ & $\overline{\mathrm{LL}}$ & $\overline{R L}$ & $\overline{\mathrm{RL}}$ & $\overline{R L}$ \\
\hline MS & MLLW CH & MS & $\overline{\mathrm{MS}}$ & $\overline{\mathrm{MS}}$ & $\overline{M S}$ & MS \\
\hline$\overline{\mathrm{MU}}$ & MLLW CH Alpha & $\overline{S R}$ & SR & SR & SR & SR \\
\hline MU & MTRU & $\overline{M U}$ & SR & SR & SR & SR \\
\hline$\overline{\mathrm{NN}}$ & $\overline{M L L W ~ C H}$ & $\overline{\mathrm{NN}}$ & SR & SR & $\mathrm{SR}$ & $\overline{S R}$ \\
\hline NT & MLLW CH & IN & IN & IN & IN & IN \\
\hline NT & MTRU & NT & NT & $\overline{\mathrm{IN}}$ & IN & IN \\
\hline$\overline{\mathrm{OR}}$ & MLLW CH & $\overline{\mathrm{OR}}$ & $\overline{O R}$ & OR & $\overline{\mathrm{OR}}$ & $\overline{O R}$ \\
\hline$\overline{\mathrm{OR}}$ & MLLW RH & $\overline{\mathrm{OR}}$ & $\overline{\mathrm{OR}}$ & $\overline{\mathrm{OR}}$ & $\overline{\mathrm{OR}}$ & $\overline{\mathrm{OR}}$ \\
\hline$\overline{\mathrm{OR}}$ & MTRU & $\mathrm{OR}$ & SR & SR & $\overline{\mathrm{SR}}$ & SR \\
\hline$\overline{\mathrm{PA}}$ & MLLW CH & $\overline{\mathrm{PA}}$ & $\overline{\mathrm{PA}}$ & $\mathrm{OR}$ & $\overline{\mathrm{OR}}$ & $\mathrm{OR}$ \\
\hline$\overline{\mathrm{PA}}$ & MTRU & $\mathrm{PA}$ & SR & SR & SR & SR \\
\hline$\overline{\mathrm{PH}}$ & MLLW CH & $\overline{\mathrm{PH}}$ & $\overline{R L}$ & $\overline{\mathrm{RL}}$ & RL & RL \\
\hline$\overline{P I}$ & MLLW CH & PI & $\overline{\mathrm{SR}}$ & SR & $\overline{S R}$ & SR \\
\hline$\overline{\mathrm{PN}}$ & MLLW CH & $\overline{\mathrm{PN}}$ & $\overline{\mathrm{PO}}$ & $\overline{P O}$ & $\overline{\mathrm{OR}}$ & $\mathrm{OR}$ \\
\hline$\overline{\mathrm{PO}}$ & MLLW CH & $\overline{\mathrm{PO}}$ & $\overline{\mathrm{PO}}$ & $\overline{\mathrm{PO}}$ & $\overline{\mathrm{OR}}$ & $\overline{O R}$ \\
\hline$\overline{\mathrm{PP}}$ & MLLW CH & PP & $\overline{\mathrm{PO}}$ & PO & $\overline{\mathrm{OR}}$ & $\mathrm{OR}$ \\
\hline PS & MLLW CH & PS & $\overline{\mathrm{RL}}$ & $\overline{\mathrm{RL}}$ & $\overline{\mathrm{RL}}$ & $\mathrm{RL}$ \\
\hline PX & MLLW CH & $\overline{\mathrm{PX}}$ & PX & $\mathrm{LA}$ & $\mathrm{RF}$ & $\mathrm{IN}$ \\
\hline$\overline{\mathrm{RF}}$ & MLLW CH Alpha & $\overline{\mathrm{RF}}$ & $\mathrm{RF}$ & RF & $\overline{\mathrm{RF}}$ & $\mathrm{IN}$ \\
\hline $\mathrm{RF}$ & MTRU & $\mathrm{RF}$ & $\mathrm{RF}$ & $\overline{\mathrm{RF}}$ & $\mathrm{RF}$ & IN \\
\hline$\overline{R L}$ & MLLW CH Alpha & RL & $\overline{R L}$ & $\overline{R L}$ & RL & RL \\
\hline$\overline{\mathrm{RL}}$ & MLLW CH & $\mathrm{RL}$ & $\overline{\mathrm{RL}}$ & $\overline{\mathrm{RL}}$ & $\overline{\mathrm{RL}}$ & $\mathrm{RL}$ \\
\hline$\overline{\mathrm{RL}}$ & MLLW RH & $\mathrm{RL}$ & $\overline{\mathrm{RL}}$ & $\overline{\mathrm{RL}}$ & $\overline{\mathrm{RL}}$ & $\mathrm{RL}$ \\
\hline$\overline{\mathrm{RL}}$ & MTRU & $\overline{\mathrm{RL}}$ & $\overline{\mathrm{RL}}$ & $\overline{\mathrm{RL}}$ & $\overline{\mathrm{RL}}$ & $\mathrm{RL}$ \\
\hline RM & MLLW CH & $\overline{\mathrm{RM}}$ & $\overline{\mathrm{PO}}$ & PO & $\overline{\mathrm{OR}}$ & $\overline{\mathrm{OR}}$ \\
\hline$\overline{\mathrm{SA}}$ & MLLW CH & SA & $\overline{\mathrm{LA}}$ & $\overline{\mathrm{LA}}$ & $\overline{\mathrm{RF}}$ & $\mathrm{IN}$ \\
\hline$\overline{\mathrm{SA}}$ & MTRU & SA & $\overline{\mathrm{LA}}$ & $\overline{\mathrm{LA}}$ & $\overline{\mathrm{RF}}$ & IN \\
\hline SL & MLLW CH & $\mathrm{LL}$ & $\mathrm{LL}$ & IN & $\mathrm{RL}$ & IN \\
\hline$\overline{S R}$ & MLLW CH Alpha & SR & SR & SR & SR & SR \\
\hline$\overline{S R}$ & MLLW CH & SR & SR & SR & $\overline{S R}$ & SR \\
\hline$\overline{S R}$ & MLLW RH & SR & SR & SR & SR & SR \\
\hline$\overline{\mathrm{SR}}$ & MTRU & SR & SR & SR & SR & SR \\
\hline WS & MLLW CH & $\overline{\mathrm{WS}}$ & $\overline{\mathrm{WS}}$ & WS & $\overline{\mathrm{WS}}$ & $\overline{\mathrm{WS}}$ \\
\hline$\overline{\text { WV }}$ & MLLW CH Alpha & SR & SR & SR & SR & SR \\
\hline$\overline{\text { WV }}$ & MLLW CH & $\overline{\mathrm{WV}}$ & $\overline{P O}$ & $\overline{P O}$ & $\overline{\mathrm{OR}}$ & $\mathrm{OR}$ \\
\hline WV & MTRU & $\overline{\text { WV }}$ & SR & SR & SR & SR \\
\hline$\overline{\mathrm{YP}}$ & MLLW CH & $\mathrm{OR}$ & OR & $\overline{\mathrm{OR}}$ & $\overline{\mathrm{OR}}$ & $\overline{\mathrm{OR}}$ \\
\hline
\end{tabular}


Table B.2 - Site Identification Abbreviation, Name, and Location

\begin{tabular}{|c|c|c|}
\hline Site ID & Site Name & State \\
\hline$\overline{\mathrm{AE}}$ & Argonne National Laboratory-East & Illinois \\
\hline$\overline{\mathrm{AL}}$ & Ames Laboratory & Iowa \\
\hline$\overline{\mathrm{AW}}$ & Argonne National Laboratory-West & Illinois \\
\hline$\overline{\mathrm{BC}}$ & Battelle Columbus Laboratories & Ohio \\
\hline$\overline{\mathrm{BN}}$ & Brookhaven Naional Laboratory & New York \\
\hline$\overline{\mathrm{BT}}$ & Bettis Atomic Power Laboratory & Pennsylvania \\
\hline $\mathrm{CI}$ & Colonie Interim Storage Site & New York \\
\hline $\mathrm{CN}$ & Charleston Naval Shipyard & \begin{tabular}{|l} 
South Carolina \\
\end{tabular} \\
\hline$\overline{\mathrm{DP}}$ & K-25 Oak Ridge National Laboratory & Tennessee \\
\hline$\overline{\mathrm{EH}}$ & Laboratory for Energy-Related Health Res & California \\
\hline ET & Energy Technology Engineering Center & \begin{tabular}{|c|c|} 
California \\
\end{tabular} \\
\hline FM & Fernald Environmental Management Project & Ohio \\
\hline$\overline{\mathrm{GA}}$ & General Atomics & California \\
\hline GJ & Grand Junction Project Office & Colorado \\
\hline IN & Idaho National Engineering Labortory & Idaho \\
\hline IT & Inhalation Toxicology Research Institute & New Mexico \\
\hline$\overline{\mathrm{KA}}$ & Knolls Atomic Power Laboratory Schenecta & New York \\
\hline$\overline{\mathrm{KC}}$ & Kansas City Plant & \begin{tabular}{|l} 
Missouri \\
\end{tabular} \\
\hline KK & Knolls Atomic Power Laboratory Kesselrin & New York \\
\hline$\overline{\mathrm{KW}}$ & Knolls Atomic Power Laboratory Windsor & Connecticut \\
\hline$\overline{\mathrm{LA}}$ & Los Alamos National Laboratory & New Mexico \\
\hline$\overline{\mathrm{LB}}$ & Lawrence Berkeley Laboratory & California \\
\hline$\overline{\mathrm{LL}}$ & Lawrence Livermore National Laboratory & California \\
\hline MD & Mound Plant & Ohio \\
\hline MI & Mare Island Naval Shipyard & California \\
\hline MS & Middlesex Sampling Plant & New Jersey \\
\hline $\mathrm{MU}$ & Missouri University & Missouri \\
\hline NN & Norfolk Naval Shipyard & Virginia \\
\hline NT & Nevada Test Site & Nevada \\
\hline$\overline{\mathrm{OR}}$ & Oak Ridge National Laboratory & Tennessee \\
\hline$\overline{\mathrm{PA}}$ & Paducah Gaseous Diffusion Plant & Kentucky \\
\hline$\overline{\mathrm{PH}}$ & Pearl Harbor Naval Shipyard & Hawaii \\
\hline PI & Pinellas Plant & Florida \\
\hline PN & Portsmouth Naval Shipyard & Maine \\
\hline$\overline{\mathrm{PO}}$ & Portsmouth Gaseous Diffusion Plant & Ohio \\
\hline$\overline{P P}$ & Princeton Plasma Physics Laboratory & New Jersey \\
\hline PS & Puget Sound Naval Shipyard & Washington \\
\hline $\mathrm{PX}$ & Pantex Plant & Texas \\
\hline $\mathrm{RF}$ & Rocky Flats & Colorado \\
\hline$\overline{\mathrm{RL}}$ & Hanford Site & Washington \\
\hline$\overline{\mathrm{RM}}$ & RMI Titanium Inc. & Ohio \\
\hline$\overline{\mathrm{SA}}$ & Sandia National Laboratory-New Mexico & New Mexico \\
\hline SL & Sandia National Laboratory-California & California \\
\hline SR & Savannah River Site & \begin{tabular}{|l} 
South Carolina \\
\end{tabular} \\
\hline$\overline{W S}$ & Weldon Spring Site Rmedial Action Projec & \begin{tabular}{|l} 
Missouri \\
\end{tabular} \\
\hline WV & West Valley Demonstration Project & New York \\
\hline$\overline{\mathrm{YP}}$ & Y-12 Oak Ridge National Laboratory & Tennessee \\
\hline
\end{tabular}




\section{Appendix C-Data Base Corrections}

Table C.1-Alpha Waste Streams

\begin{tabular}{|c|c|c|c|}
\hline $\begin{array}{c}\text { Waste } \\
\text { Stream ID }\end{array}$ & Name of Waste Stream & $\begin{array}{l}\text { Inventory } \\
\text { Volume }\left(\mathrm{m}^{3}\right)\end{array}$ & $\begin{array}{c}\text { Projected } \\
20-\text { Year } \\
\text { Volume }\left(\mathrm{m}^{3}\right) \\
\end{array}$ \\
\hline BT-W001 & OIL CONTAINING HEAVY METALS \#1 & 10.7 & 0.21 \\
\hline IN-W038 & TAN DECON SOLVENTS WASTES & 5.9 & 0 \\
\hline IN-W039 & TAN DECON HEAVY METAL SOLIDS AND DEBRIS & 0.32 & 0 \\
\hline IN-W158 & COMBUSTIBLES (a-LLW): DRY PAPER AND RAGS & 3150.63 & 0 \\
\hline IN-W160 & COMBUSTIBLES (a-LLW): MOIST PAPER AND RAGS & 1452.4 & 0 \\
\hline IN-W162 & CONCRETE-BRICK (a-LLW): FIREBRICK & 183.48 & 0 \\
\hline IN-W165 & $\begin{array}{l}\text { CEMENTED SLUDGES (a-LLW): SOLID INORGANIC } \\
\text { PROCESS SOLUTION }\end{array}$ & 4.03 & 0 \\
\hline IN-W168 & CEMENTED SLUDGES (a-LLW): SOLID ORGANICS & 5.09 & 0 \\
\hline IN-W173 & COMBUSTIBLES (a-LLW): COMBUSTIBLES & 33.71 & 0 \\
\hline IN-W175 & CEMENTED SLUDGES (a-LLW): HIGH LEVEL ACID & 39.86 & 0 \\
\hline IN-W176 & $\begin{array}{l}\text { CEMENTED SLUDGES (a-LLW): HIGH LEVEL } \\
\text { CAUSTIC }\end{array}$ & 178.93 & 0 \\
\hline IN-W178 & $\begin{array}{l}\text { CEMENTED SLUDGES (a-LLW): HIGH LEVEL } \\
\text { SLUDGE/CEMENT }\end{array}$ & 880.22 & 0 \\
\hline IN-W180 & $\begin{array}{l}\text { CEMENTED SLUDGES (a-LLW): BUILDING } 776 \\
\text { PROCESS SLUDGE }\end{array}$ & 63.82 & $\overline{0}$ \\
\hline IN-W182 & CEMENTED SLUDGES (a-LLW): LAUNDRY SLUDGE & 25.36 & 0 \\
\hline $\mathrm{IN}-\mathrm{W} 183$ & $\begin{array}{l}\text { BENELEX, PLEXIGLASS (a-LLW): BENELEX AND } \\
\text { PLEXIGLASS }\end{array}$ & 3.82 & $\overline{0}$ \\
\hline IN-W184 & $\begin{array}{l}\text { BENELEX, PLEXIGLASS (a-LLW): BENELEX AND } \\
\text { PLEXIGLASS }\end{array}$ & 55.37 & 0 \\
\hline IN-W185 & COMBUSTIBLES (a-LLW): COMBUSTIBLE WASTE & 371.1 & 0 \\
\hline IN-W190 & $\begin{array}{l}\text { UNCEMENTED INORGANIC SLUDGE (a-LLW): FIRST } \\
\text { STAGE SLUDGE }\end{array}$ & 58.93 & 0 \\
\hline IN-W191 & $\begin{array}{l}\text { UNCEMENTED INORGANIC SLUDGE (a-LLW): } \\
\text { SECOND STAGE SLUDGE }\end{array}$ & 342.38 & $\overline{0}$ \\
\hline IN-W192 & $\begin{array}{l}\text { UNCEMENTED INORGANIC SLUDGE (a-LLW): } \\
\text { BUILDING } 374 \text { DRY SLUDGE }\end{array}$ & 464.28 & 0 \\
\hline IN-W194 & $\begin{array}{l}\text { UNCEMENTED INORGANIC SLUDGE (a-LLW): } \\
\text { RESEARCH GENERATED WASTE NONCOMPACTIBLE } \\
\text { SOLIDS OR SOLIDS WET S }\end{array}$ & 285.33 & 0 \\
\hline N-W195 & $\begin{array}{l}\text { UNCEMENTED INORGANIC SLUDGE (a-LLW): } \\
\text { CERTIFIED SOLID LAB WASTE }\end{array}$ & 2.54 & 0 \\
\hline NN-W196 & $\begin{array}{l}\text { UNCEMENTED INORGANIC SLUDGE (a-LLW): } \\
\text { FILTER SLUDGE }\end{array}$ & 0.21 & 0 \\
\hline N-W215 & $\begin{array}{l}\text { UNCEMENTED INORGANIC SLUDGE (a-LLW): } \\
\text { CEMENTED SLUDGE }\end{array}$ & 4.88 & 0 \\
\hline IN-W217 & $\begin{array}{l}\text { COMBUSTIBLES (a-LLW): PLASTICS, TEFLON, } \\
\text { WASH, PVC }\end{array}$ & 352.94 & 0 \\
\hline IN-W223 & $\begin{array}{l}\text { CONCRETE - BRICK (a-LLW): OIL DRI RESIDUE } \\
\text { FROM INCINERATOR }\end{array}$ & 3.18 & 0 \\
\hline IN-W224 & COMBUSTIBLES (a-LLW): WOOD & 91.3 & 0 \\
\hline
\end{tabular}




\begin{tabular}{|c|c|c|c|}
\hline $\begin{array}{c}\text { Waste } \\
\text { Stream ID }\end{array}$ & Name of Waste Stream & $\begin{array}{c}\text { Inventory } \\
\text { Volume }\left(\mathrm{m}^{3}\right)\end{array}$ & $\begin{array}{c}\text { Projected } \\
20-Y e a r \\
\text { Volume }\left(\mathrm{m}^{3}\right)\end{array}$ \\
\hline $\mathrm{IN}-\mathrm{W} 226$ & $\begin{array}{l}\text { COMBUSTIBLES (a-LLW): COMBUSTIBLE } \\
\text { EQUIPMENT BOXES OR FLOOR SWEEPINGS AND } \\
\text { RUST }\end{array}$ & 9.93 & 0 \\
\hline $\mathrm{IN}-\mathrm{W} 227$ & $\begin{array}{l}\text { COMBUSTIBLES (a-LLW): LOW SPECIFIC ACTIVITY } \\
\text { PLASTICS, PAPER ETC. } \\
\end{array}$ & 92.37 & 0 \\
\hline IN-W229 & $\begin{array}{l}\text { CEMENTED SLUDGES (a-LLW): SPECIAL SET UPS } \\
\text { (CEMENT) }\end{array}$ & 103.88 & 0 \\
\hline $\mathrm{IN}-\mathrm{W} 231$ & $\begin{array}{l}\text { CONCRETE - BRICK (a-LLW): INORGANIC SOLID } \\
\text { WASTE }\end{array}$ & 12.3 & 0 \\
\hline IN-W232 & FILTERS (a-LLW): HEPA FILTER WASTE & 69.16 & 0 \\
\hline IN-W233 & FILTERS (a-LLW): FULFLO INCINERATOR FILTERS & 0.21 & 0 \\
\hline IN-W234 & FILTERS (a-LLW): ABSOLUTE 8 X8 FILTERS & 16.54 & 0 \\
\hline IN-W235 & $\begin{array}{l}\text { FILTERS (a-LLW): INSULATION AND CHEMICAL } \\
\text { WARFARE SERVICE FILTER MEDIA }\end{array}$ & 240.74 & 0 \\
\hline IN-W237 & FILTERS (a-LLW): INSULATION & 50.45 & 0 \\
\hline IN-W238 & $\begin{array}{l}\text { FILTERS (a-LLW): CEMENTED INSULATION AND } \\
\text { FILTER MEDIA }\end{array}$ & 94.74 & 0 \\
\hline IN-W239 & $\begin{array}{l}\text { FILTERS (a-LLW): CHEMICAL WARFARE SERVICE } \\
\text { FILTERS }\end{array}$ & 873.45 & 0 \\
\hline IN-W241 & GLASS (a-LLW): GLASS WASTE & 6.35 & 0 \\
\hline IN-W242 & GLASS (a-LLW): GLASS & 95.4 & 0 \\
\hline IN-W244 & GLASS (a-LLW): UNLEACHED RASHIG RINGS & 164.72 & 0 \\
\hline $\mathrm{IN}-\mathrm{W} 248$ & GLASS (a-LLW): LEACHED RASHIG RINGS & 138.44 & 0 \\
\hline IN-W251 & GLOVEBOX GLOVES (a-LLW): LEADED RUBBER & 2.33 & 0 \\
\hline $\mathrm{IN}-\mathrm{W} 253$ & $\begin{array}{l}\text { GLOVEBOX GLOVES (a-LLW): LEADED RUBBER } \\
\text { GLOVES AND APRONS }\end{array}$ & 4.88 & 0 \\
\hline IN-W255 & $\begin{array}{l}\text { GLOVEBOX GLOVES (a-LLW): LEADED RUBBER } \\
\text { GLOVES AND APRONS }\end{array}$ & 1.06 & 0 \\
\hline $\mathrm{IN}-\mathrm{W} 258$ & $\begin{array}{l}\text { RADIOACTIVE SOURCES (a-LLW): ALPHA HOT CELL } \\
\text { WASTE }\end{array}$ & 47.81 & 0 \\
\hline IN-W261 & PARTICULATE WASTES (a-LLW): DIRT & 99.64 & 0 \\
\hline IN-W262 & $\begin{array}{l}\text { PARTICULATE WASTE (a-LLW): CONTAMINATED } \\
\text { SOIL }\end{array}$ & 85.59 & 0 \\
\hline IN-W264 & $\begin{array}{l}\text { PARTICULATE WASTES (a-LLW): BLACKTOP, } \\
\text { CONCRETE, DIRT AND SAND }\end{array}$ & 368.04 & 0 \\
\hline IN-W266 & PARTICULATE WASTES (a-LLW): GRIT & 0.85 & 0 \\
\hline IN-W268 & $\begin{array}{l}\text { PARTICULATE WASTES (a-LLW): LABORATORY } \\
\text { WASTE }\end{array}$ & 3.6 & 0 \\
\hline IN-W270 & PARTICULATE WASTES (a-LLW): DIRT & 28.62 & 0 \\
\hline NN-W273 & $\begin{array}{l}\text { NONMETAL MOLDS AND CRUCIBLES (a-LLW): } \\
\text { GRAPHITE CORES }\end{array}$ & 1.27 & 0 \\
\hline N-W274 & $\begin{array}{l}\text { NONMETAL MOLDS AND CRUCIBLES (a-LLW): } \\
\text { GRAPHITE }\end{array}$ & 18.44 & 0 \\
\hline IN-W277 & $\begin{array}{l}\text { MISCELLANEOUS (PAPER, METAL, ETC.) (a-LLW): } \\
\text { LOW SPECIFIC ACTIVITY METAL, GLASS, ETC. }\end{array}$ & 1064.98 & 0 \\
\hline IN-W279 & $\begin{array}{l}\text { MISCELLANEOUS (PAPER, METAL, ETC.) (a-LLW): } \\
\text { NONCOMBUSTIBLE EQUIPMENT BOXES }\end{array}$ & 836.88 & 0 \\
\hline IN-W282 & MISCELLANEOUS (PAPER, METAL, ETC.) (a-LLW): & 24.17 & 0 \\
\hline
\end{tabular}




\begin{tabular}{|c|c|c|c|}
\hline $\begin{array}{c}\text { Waste } \\
\text { Stream ID }\end{array}$ & Name of Waste Stream & $\begin{array}{c}\text { Inventory } \\
\text { Volume }\left(\mathrm{m}^{3}\right)\end{array}$ & $\begin{array}{c}\text { Projected } \\
20-\text { Year } \\
\text { Volume }\left(\mathrm{m}^{3}\right) \\
\end{array}$ \\
\hline & AMERICIUM PROCESS RESIDUE & & \\
\hline IN-W284 & $\begin{array}{l}\text { MISCELLANEOUS (PAPER, METAL, ETC.) (a-LLW): } \\
\text { NONCOMBUSTIBLE SOLIDS }\end{array}$ & 80.5 & 0 \\
\hline IN-W286 & $\begin{array}{l}\text { MISCELLANEOUS (PAPER, METAL, ETC.) (a-LLW): } \\
\text { DDW NONCOMBUSTIBLE SOLIDS }\end{array}$ & 0.21 & 0 \\
\hline IN-W288 & $\begin{array}{l}\text { MISCELLANEOUS(PAPER, METAL, ETC.) (a-LLW): } \\
\text { GENERAL PLANT WASTE }\end{array}$ & 371 & 0 \\
\hline IN-W290 & $\begin{array}{l}\text { MISCELLANEOUS(PAPER, METAL, ETC.) (a-LLW): } \\
\text { CUT UP GLOVE BOXES }\end{array}$ & 38.5 & 0 \\
\hline IN-W292 & $\begin{array}{l}\text { METALS (a-LLW): METAL, EQUIPMENT, PIPES, } \\
\text { VALVES, ETC. }\end{array}$ & 2.76 & 0 \\
\hline IN-W293 & $\begin{array}{l}\text { METALS (a-LLW): LEACHED NON SPECIAL SOURCE } \\
\text { METAL }\end{array}$ & 164.33 & 0 \\
\hline IN-W295 & METALS (a-LLW): NON SPECIAL SOURCE METAL & 6688.03 & 0 \\
\hline IN-W297 & METALS (a-LLW): TANTALUM & 28.62 & 0 \\
\hline IN-W299 & METALS (a-LLW): METAL WASTE & 147.54 & 0 \\
\hline IN-W303 & $\begin{array}{l}\text { METALS (a-LLW): NONCOMPRESSIBLE, } \\
\text { NONCOMBUSTIBLE }\end{array}$ & 62.33 & 0 \\
\hline IN-W307 & $\begin{array}{l}\text { UNCATEGORIZED (a-LLW): NOT RECORDED - } \\
\text { UNKNOWN }\end{array}$ & 136.7 & 0 \\
\hline IN-W310 & $\begin{array}{l}\text { UNCEMENTED ORGANIC SLUDGE (a-LLW): } \\
\text { ORGANIC SETUPS, OIL SOLIDS }\end{array}$ & 1001.85 & 0 \\
\hline IN-W313 & SALTS (a-LLW): EVAPORATOR SALTS & 13.56 & 0 \\
\hline IN-W316 & RESINS (a-LLW): LEACHED AND CEMENTED RESIN & 8.9 & 0 \\
\hline IN-W318 & RESINS (a-LLW): LEACHED RESIN & 0.42 & 0 \\
\hline IN-W320 & RESINS (a-LLW): UNLEACHED ION COLUMN RESIN & 1.91 & 0 \\
\hline IN-W324 & $\begin{array}{l}\text { UNKNOWN (a-LLW):LOW SPECIFIC ACTIVITY }<100 \\
\text { nCi/g NONCOMBUSTIBLE }\end{array}$ & 27.14 & 0 \\
\hline IN-W326 & UNKNOWN (a-LLW): $<10 \mathrm{nCi} / \mathrm{g}$ NONCOMBUSTIBLE & 0.21 & 0 \\
\hline IN-W328 & $\begin{array}{l}\text { UNKNOWN (a-LLW): LOW SPECIFIC ACTIVITY }<100 \\
\text { nCi/g COMBUSTIBLE }\end{array}$ & 152.85 & 0 \\
\hline IN-W331 & UNKNOWN (a-LLW): SOLIDIFIED SOLUTIONS & 0.64 & 0 \\
\hline IN-W333 & UNKNOWN (a-LLW): PAPER, METALS, GLASS & 21 & 0 \\
\hline IN-W335 & UNKNOWN (a-LLW): COMBUSTIBLE SOLIDS & 14 & 0 \\
\hline IN-W343 & UNKNOWN (a-LLW): CHEM CELK RIP-OUT & 28.53 & 0 \\
\hline IN-W344 & UNKNOWN (a-LLW): TRU SCRAP & 4.44 & 0 \\
\hline IN-W346 & UNKNOWN (a-LLW): ABSORBED LIQUIDS & 13.46 & 0 \\
\hline IN-W352 & UNCATEGORIZED (a-LLW): PRE 73 DRUMS & 3004.19 & 0 \\
\hline IT-W001 & ACTINIDE LSC VIAL WASTE & 1.02 & 0.43 \\
\hline LA-W006 & PROCESS RESIDUES - CHROMIUM & 0.42 & 2.78 \\
\hline LA-W007 & LEAD & 163.33 & 972.62 \\
\hline LA-W010 & SOLVENT CONTAMINATED DEBRIS - F002 & 21.84 & 113.06 \\
\hline LA-W012 & IGNITABLE LIQUIDS & 79.31 & 351.005 \\
\hline LA-W015 & REACTIVE SOLUTIONS & 2.04 & 12.335 \\
\hline LA-W017 & ANALYTICAL LABORATORY WASTE - BARIUM & 2.53 & 16.13 \\
\hline LA-W018 & ANALYTICAL LABORATORY WASTE - CADMIUM & 0.32 & 0.75 \\
\hline LA-W019 & ANALYTICAL LABORATORY WASTE - CHROMIUM & 4.59 & 3.055 \\
\hline
\end{tabular}




\begin{tabular}{|c|c|c|c|}
\hline $\begin{array}{c}\text { Waste } \\
\text { Stream ID }\end{array}$ & Name of Waste Stream & $\begin{array}{l}\text { Inventory } \\
\text { Volume }\left(\mathrm{m}^{3}\right)\end{array}$ & $\begin{array}{c}\text { Projected } \\
\text { 20-Year } \\
\text { Volume }\left(\mathrm{m}^{3}\right) \\
\end{array}$ \\
\hline LA-W020 & ANALYTICAL LABORATORY WASTE - LEAD & 7.97 & 46.07 \\
\hline LA-W021 & MERCURY & 10.49 & 44.54 \\
\hline LA-W022 & ANALYTICAL LABORATORY WASTE - SELENIUM & 0.45 & 2.995 \\
\hline LA-W023 & PHOTOGRAPHIC FIXER - SILVER & 0.53 & 3.165 \\
\hline LA-W024 & SPENT SOLVENTS - F001 & 8.85 & 53.34 \\
\hline LA-W025 & SPENT SOLVENTS - F002 & 12.72 & 73.945 \\
\hline LA-W026 & SPENT SOLVENTS - F003 & 16.16 & 84.775 \\
\hline LA-W033 & U-WASTE LAB PACKS & 3.57 & 13.03 \\
\hline LB-W007 & $\begin{array}{l}\text { ELEMENTAL LEAD (NONACTIVATED AND } \\
\text { ACTIVATED LEAD) } \\
\end{array}$ & 0.4 & 4 \\
\hline LL-W001 & LOW LEVEL MIXED ORGANIC FLUIDS AND GLASS & 3 & 55.5 \\
\hline LL-W003 & LOW LEVEL MIXED INORGANIC TRASH-1 & 0.4 & 7.4 \\
\hline LL-W004 & LOW LEVEL MIXED WASH WATERS & 25 & 462.5 \\
\hline LL-W005 & LOW LEVEL MIXED SOIL AND SAND & 4 & 74 \\
\hline LL-W006 & LOW LEVEL MIXED SCRAP METAL & 6 & 111 \\
\hline LL-W014 & LOW LEVEL MIXED OILS & 6 & 111 \\
\hline LL-W016 & LOW LEVEL MIXED ORGANIC LIQUIDS & 1.8 & 33.3 \\
\hline LL-W017 & LOW LEVEL MIXED INORGANIC TRASH-3 & 25 & 462.5 \\
\hline LL-W023 & Contaminated Soils & 0.2 & 3.7 \\
\hline LL-W025 & Stabilized Sludges and Particulates & 30 & 555 \\
\hline MD-W001 & SCINTILLATION COCKTAIL & 43.2 & 0 \\
\hline MD-W004 & LEAD - LLW & 5 & 0 \\
\hline MD-W007 & LEAD WASTE DRAINED BATTERIES & 0.85 & 0.0792 \\
\hline MD-W010 & LAB PACKS WITH METALS & 0.06 & 0 \\
\hline MD-W011 & LAB PACKS WITHOUT METALS & 0.1072 & 0 \\
\hline MD-W012 & LEAD LOADED GLOVES --LLW & 0.0204 & 0 \\
\hline MD-W013 & WASTE OILS & 25.99 & 4.2 \\
\hline MD-W014 & NEWLY DISCOVERED POTENTIALLY MIXED WASTE & 0 & 0 \\
\hline MU-W001 & Mixed Low Level Waste & 0.43 & 1.02 \\
\hline RF-W003 & Cemented Composite Chips/LLM & 90.6 & 0 \\
\hline RF-W005 & Metal/LLM & 28.1 & 160 \\
\hline RF-W006 & Combustibles/LLM & 410.4 & 1052.4 \\
\hline RF-W007 & Roaster Oxide/LLM & 82.74 & 0 \\
\hline RF-W009 & Solidified Bypass Sludge/LLM & 458.01 & 356 \\
\hline RF-W014 & Cutoff Sludge/LLM & 7.95 & 0 \\
\hline RF-W015 & FBI Oil/LLM & 109.64 & 0 \\
\hline RF-W016 & Acid/LLM & 9.5 & 0 \\
\hline RF-W018 & Pondcrete/LLM & 5905.15 & 1036.8 \\
\hline RF-W019 & Saltcrete/LLM & 3280.86 & 6980 \\
\hline RF-W020 & Beryllium Fines/LLM & 1.47 & 2.8 \\
\hline RF-W021 & Electrochemical Milling Sludge/LLM & 1.5 & 0 \\
\hline RF-W022 & Incinerator Ash/LLM & 8.82 & 0 \\
\hline RF-W023 & Lead/LLM & 31.92 & 35.8 \\
\hline RF-W024 & Ground Glass/LLM & 4.41 & 38.6 \\
\hline RF-W025 & Used Absorbents/LLM & 0.21 & 0 \\
\hline RF-W027 & Paints/LLM & 0.38 & 0 \\
\hline RF-W030 & Leaded Gloves/LLM & 2.73 & 11.2 \\
\hline
\end{tabular}




\begin{tabular}{|c|c|c|c|}
\hline $\begin{array}{c}\text { Waste } \\
\text { Stream ID }\end{array}$ & Name of Waste Stream & $\begin{array}{c}\text { Inventory } \\
\text { Volume }\left(\mathrm{m}^{3}\right)\end{array}$ & $\begin{array}{c}\text { Projected } \\
20-\text { Year } \\
\text { Volume }\left(\mathrm{m}^{3}\right)\end{array}$ \\
\hline RF-W031 & Leaded Gloves-Acid Contaminated/LLM & 0.21 & 0 \\
\hline RF-W035 & Glovebox Parts w/Lead/LLM & 6.76 & 42.2 \\
\hline RF-W042 & Heavy Metal (non-SS)/LLM & 1.26 & 0 \\
\hline RF-W043 & Glass/LLM & 4.41 & 17.8 \\
\hline RF-W044 & Solidified Process Solids/LLM & 4.75 & 0 \\
\hline RF-W045 & Insulation/LLM & 1.89 & 11 \\
\hline RF-W046 & Organics Discard Level/LLM & 30.89 & 11.2 \\
\hline RF-W047 & Analytical Lab Solutions/LLM & 0.63 & 12.4 \\
\hline RF-W048 & Sand From Button Breakout/LLM & 0.21 & 0 \\
\hline RF-W049 & Miscellaneous Liquids/LLM & 19.11 & 0 \\
\hline RF-W050 & Soil and Cleanup Debris/LLM & 43.61 & 1150 \\
\hline RF-W051 & Excess Chemicals/LLM & 5.67 & 180 \\
\hline RF-W053 & Silver Nitrate/LLM & 0.84 & 0 \\
\hline RF-W054 & Cyanides/LLM & 1.05 & 0 \\
\hline RF-W055 & Turnings/LLM & 1.47 & 42 \\
\hline RF-W061 & Misc Pu Recovery Byproducts/LLM & 0.21 & 0 \\
\hline RF-W062 & Solidified Organics/LLM & 0.21 & 7 \\
\hline RF-W064 & Solar Pond Water/LLM & 45425 & 2000 \\
\hline RF-W071 & Particulate Sludge/LLM & 4.32 & 0 \\
\hline RF-W073 & Organic Resins/LLM & 0.63 & 0 \\
\hline RF-W074 & Cemented Filters/LLM & 23.2 & 36.4 \\
\hline RF-W075 & Filters \& Media/LLM & 5.67 & 91.2 \\
\hline RF-W077 & Acidic Oils/LLM & 1.68 & 0 \\
\hline RF-W078 & Wastewater/LLM & 0 & 0 \\
\hline RF-W079 & Wet Slurry / LLM & 0 & 200 \\
\hline SR-W025 & SOLVENT WASTE $<100$ NCI/G TRU RAD & 2791.1 & 0 \\
\hline SR-W033 & THIRDS WASTE $<100 \mathrm{~N}$ CI/G TRU RAD & 8 & 644 \\
\hline SR-W045 & TRI-BUTYL-PHOSPHATE \& N-PARAFFIN & 105.8 & 0 \\
\hline SR-W046 & CONSOLIDATED INCINERATOR (CIF) ASH & 0 & 527 \\
\hline SR-W048 & WASTE SITES/SPILL SITE SOIL & 18.1 & 0 \\
\hline WV-W002 & LOW LEVEL RADIOACTIVE LEAD & 1.2183 & 0.714 \\
\hline WV-W003 & ORGANIC EXTRACTION WASTE & 0.316 & 0.2 \\
\hline WV-W004 & ZINC BROMIDE & 0.114 & 10 \\
\hline WV-W005 & DECON SOLUTION & 0.0978 & 0.0973 \\
\hline WV-W006 & PU SCINTILLATION & 0.038 & 0 \\
\hline WV-W007 & PYRIDINE/CYANIDE WASTE & 0.038 & 0 \\
\hline WV-W008 & INSTRUMENT OIL W/MERCURY & 0.0038 & 0 \\
\hline WV-W009 & METHANOL & 0.0038 & 0.04 \\
\hline WV-W010 & PAINT & 0.844 & 0.1 \\
\hline WV-W012 & PAINT W/ METALS & 0.0232 & 0.0097 \\
\hline WV-W013 & PU AQUEOUS WASTE & 0.684 & 0.2 \\
\hline WV-W014 & SR ORGANIC WASTE & 0.156 & 0.2 \\
\hline WV-W015 & LEAD ACID BATTERIES & 0.208 & 0.48 \\
\hline WV-W016 & TOLUENE & 0.0005 & 0 \\
\hline WV-W017 & TC AQUEOUS WASTE & 0.017 & 0.48 \\
\hline WV-W018 & DU SQUEEZE & 0.03 & 0 \\
\hline WV-W019 & FUELS, OILS, AND LUBRICATING FLUIDS & 4.0739 & 13.334 \\
\hline
\end{tabular}

Appendix-13 


\begin{tabular}{|l|l|c|c|}
\hline $\begin{array}{c}\text { Waste } \\
\text { Stream ID }\end{array}$ & Name of Waste Stream & $\begin{array}{c}\text { Inventory } \\
\text { Volume }\left(\mathrm{m}^{3}\right)\end{array}$ & $\begin{array}{c}\text { Projected } \\
\text { 20-Year } \\
\text { Volume }\left(\mathrm{m}^{3}\right)\end{array}$ \\
\hline WV-W020 & MERCURY WASTES & 1.9633 & 0.008 \\
\hline WV-W021 & ORGANIC LIQUID - IGNITABLE & 0.019 & 0 \\
\hline WV-W022 & SPENT DEGREASER MIXTURES & 0.779 & 0 \\
\hline WV-W023 & ACIDIC AQUEOUS WASTES & 0.0048 & 0.0045 \\
\hline WV-W025 & CAUSTIC WASTES & 0.613 & 0 \\
\hline WV-W026 & Acidic Organic Wastes & 0.0022 & 0.0013 \\
\hline WV-W027 & Oxidizers & 0.6432 & 0.6432 \\
\hline WV-W028 & Solids Contaminated with Oil & 0.0445 & 0.0445 \\
\hline WV-W029 & Immersion Bucket Solution & 0.0343 & 0.1043 \\
\hline WV-W030 & AQUEOUS LAB WASTE & 0.0023 & 0.0023 \\
\hline WV-W031 & Reactive chemicals & 0.0005 & 0.0005 \\
\hline WV-W032 & Commercial Chemical Products (Ignitable) & 0 & 0.004 \\
\hline WV-W033 & SOLID METAL WASTES & 0.0008 & 0.0008 \\
\hline WV-W034 & ACIDIC METAL AQUEOUS WASTES & 0.0003 & 0.0003 \\
\hline WV-W035 & SAMPLING WASTE & 0.0145 & 0.0145 \\
\hline WV-W036 & LOW LEVEL PAINT (DRY) WITH METALS & 5.778 & 5.778 \\
\hline WV-W037 & DECONTAMINATED SUPERNATANT & 0 & 0.0390 \\
\hline WV-W038 & FLUORESCENT LIGHTBULBS & 0.0167 & 0.0167 \\
\hline MD-W009 & ABSORBED OIL, PCB, PLUTONIUM & 0.227 & 0 \\
\hline RF-W002 & PCB (Solids)/LLM & 10.5 & 0 \\
\hline RF-W017 & PCB Liquids/LLM & 1.05 & 0 \\
\hline WV-W039 & PCB CAPACITORS & 2.55 & 0.2682 \\
\hline WV-W040 & PCB CONTAMINATED MATERIAL & 2.55 & 0 \\
\hline IN-W193 & UNCEMENTED INORGANIC SLUDGE (a-LLW): & 0.42 & 0 \\
\hline SN-W301 & RADIOACTIVE SOURCES (a-LLW): COMBUSTIBLE \\
\hline IN-W340 & UAB WASTE & 5.94 & 0 \\
\hline & Laboratory GlasSWasre, paper, poly, and miscellaneous h & 0.42 & 0 \\
\hline
\end{tabular}


Table C-2: Projected Volume Corrections

\begin{tabular}{|c|c|c|c|c|c|c|c|c|c|}
\hline $\begin{array}{l}\text { Unique } \\
\text { Identifier }\end{array}$ & 20 Year & $\begin{array}{l}\text { Calcu- } \\
\text { lated } \\
\text { Proi. }\end{array}$ & 1993 & 1994 & 1995 & 1996 & 1997 & $\begin{array}{l}1990 \\
2002\end{array}$ & $\begin{array}{l}2003- \\
2022\end{array}$ \\
\hline AE-W011 & 25.6 & 6.4 & 1.2 & 1.2 & 1.2 & 1.2 & 1.2 & & \\
\hline AE-W012 & 3.8 & .9 & .1 & .1 & .1 & .1 & .1 & & \\
\hline AE-W013 & 2.5 & 1.4 & 1.2 & & & & & & \\
\hline AE-W016 & 30 & 7.5 & 1.5 & 1.5 & 1.5 & 1.5 & 1.5 & & \\
\hline AE-W017 & 1,850 & 462.5 & 92.5 & 92.5 & 92.5 & 92.5 & 92.5 & & \\
\hline AE-W018 & 15.2 & 3.8 & .7 & .7 & .7 & .7 & .7 & & \\
\hline AE-W020 & 2.2 & 1.5 & & & 1.3 & & & & \\
\hline AE-W021 & 6,000 & 1,500 & 300 & 300 & 300 & 300 & 300 & & \\
\hline AE-W022 & 34 & 8.5 & 1.7 & 1.7 & 1.7 & 1.7 & 1.7 & & \\
\hline AE-W024 & 8.2 & 2 & .4 & .4 & .4 & .4 & .4 & & \\
\hline AE-W026 & 1 & .2 & & & & & & & \\
\hline AE-W027 & .8 & .2 & & & & & & & \\
\hline AE-W028 & .2 & & & & & & & & \\
\hline AE-W030 & 5.6 & 1.4 & .2 & .2 & .2 & .2 & .2 & & \\
\hline AE-W031 & 10.2 & 2.5 & .5 & .5 & .5 & .5 & .5 & & \\
\hline AE-W034 & 8 & 2 & .4 & .4 & .4 & .4 & .4 & & \\
\hline AE-W037 & 145.4 & 36.3 & 7.2 & 7.2 & 7.2 & 7.2 & 7.2 & & \\
\hline AE-W038 & 4 & 1 & .2 & .2 & .2 & .2 & .2 & & \\
\hline AE-W039 & .2 & & & & & & & & \\
\hline AW-W001 & 1 & .2 & & & & & & & \\
\hline AW-W002 & 1.4 & .3 & & & & & & & \\
\hline AW-W006 & 3.4 & .8 & .1 & 1 & .1 & .1 & .1 & & \\
\hline AW-W007 & 4.8 & 1.2 & .2 & .2 & .2 & .2 & .2 & & \\
\hline AW-W009 & 2 & .5 & .1 & .1 & .1 & .1 & .1 & & \\
\hline AW-W012 & 2 & .4 & & .1 & .1 & .1 & .1 & & \\
\hline $\mathrm{AW}-\mathrm{W} 013$ & .4 & .1 & & & & & & & \\
\hline AW-W014 & .4 & .1 & & & & & & & \\
\hline AW-W015 & .3 & & & & & & & & \\
\hline AW-W016 & 4.1 & 8 & & .2 & .2 & .2 & .2 & & \\
\hline \multicolumn{10}{|l|}{ AW-W018 } \\
\hline AW-W020 & .8 & .2 & & & & & & & \\
\hline AW-W021 & 2.8 & .6 & & .1 & .1 & .1 & .1 & & \\
\hline AW-W022 & .3 & & & & & & & & \\
\hline BN-W001 & 1.8 & .4 & & & & & & & \\
\hline BN-W002 & 2 & .5 & .1 & .1 & .1 & .1 & .1 & & \\
\hline BN-W003 & .4 & .1 & & & & & & & \\
\hline BN-W004 & .4 & .1 & & & & & & & \\
\hline BN-W005 & .4 & .1 & & & & & & & \\
\hline BN-W006 & 2.9 & .7 & .1 & .1 & .1 & .1 & .1 & & \\
\hline BN-W007 & .4 & .1 & & & & & & & \\
\hline BN-W008 & .4 & .1 & & & & & & & \\
\hline BN-W009 & .6 & .1 & & & & & & & \\
\hline BN-W010 & 100 & 25 & 5 & 5 & 5 & 5 & 5 & & \\
\hline BT-W019 & 11.9 & 2.5 & & .6 & .6 & .6 & .6 & & \\
\hline GJ-W001 & .2 & .3 & & & & & & & .2 \\
\hline
\end{tabular}




\begin{tabular}{|c|c|c|c|c|c|c|c|c|c|}
\hline $\begin{array}{l}\text { Unique } \\
\text { Identifier }\end{array}$ & 20 Year & $\begin{array}{l}\text { Calcu- } \\
\text { lated } \\
\text { Proj. }\end{array}$ & 1993 & 1994 & 1995 & 1996 & 1997 & $\begin{array}{l}1990 \\
2002\end{array}$ & $\begin{array}{l}2003- \\
2022\end{array}$ \\
\hline GJ-WO02 & .3 & .5 & & & & & & & .3 \\
\hline GJ-W008 & .2 & .4 & & & & & & & .2 \\
\hline GJ-W009 & .1 & .1 & & & & & & & .1 \\
\hline IN-W002 & .1 & & & & & & & & \\
\hline IN-W018 & .6 & 2 & .1 & & & & & & \\
\hline IN-W027 & 25.6 & 6.4 & 1.2 & 1.2 & 1.2 & 1.2 & 1.2 & & \\
\hline IN-W028 & 100 & 25 & 5 & 5 & 5 & 5 & 5 & & \\
\hline IN-W053 & 8.4 & 2.1 & .4 & 4 & .4 & .4 & .4 & & \\
\hline IN-W060 & 25 & 6.2 & 1.2 & 1.2 & 1.2 & 1.2 & 1.2 & & \\
\hline IN-W061 & .4 & .1 & & & & & & & \\
\hline IN-W072 & 20 & 5 & 1 & 1 & 1 & 1 & 1 & & \\
\hline IN-W073 & .1 & .1 & & & & & & & \\
\hline N-W074 & 50 & 12.5 & 2.5 & 2.5 & 2.5 & 2.5 & 2.5 & & \\
\hline IN-W075 & 25.8 & 6.4 & 1.2 & 1.2 & 1.2 & 1.2 & 1.2 & & \\
\hline IN-W076 & 1.6 & .4 & & & & & & & \\
\hline IN-W078 & 32.7 & 12.6 & 2.5 & 2.5 & 2.5 & 2.5 & 2.5 & & \\
\hline IN-W079 & 276 & 69 & 13.8 & 13.8 & 13.8 & 13.8 & 13.8 & & \\
\hline IN-W082 & 8.4 & 9.2 & & .8 & .8 & .8 & .8 & 4.2 & 1.6 \\
\hline IN-W087 & 1.1 & 1.3 & .1 & 1 & 1 & .1 & .1 & .5 & .3 \\
\hline IN-W089 & & & & & & & & & \\
\hline IN-W104 & 4 & 1 & 2 & .2 & .2 & 2 & 2 & & \\
\hline IN-W106 & 19.5 & 12 & 1.5 & 4 & 4 & 2 & .5 & & \\
\hline IN-W109 & 80 & 120 & 4 & 4 & 4 & 4 & 4 & 20 & 80 \\
\hline IN-W110 & 140 & 210 & 7 & 7 & 7 & 7 & 7 & 35 & 140 \\
\hline IN-W111 & 504 & 756 & 25.2 & 25.2 & 25.2 & 25.2 & 25.2 & 126 & 504 \\
\hline IN-W112 & 136 & 204 & 6.8 & 6.8 & 6.8 & 6.8 & 6.8 & 34 & 136 \\
\hline IN-W113 & 14,000 & 21,000 & 700 & 700 & 700 & 700 & 700 & 3,500 & 14,000 \\
\hline IN-W114 & 9,300 & 13,950 & 465 & 465 & 465 & 465 & 465 & 2,325 & 9,300 \\
\hline IN-W115 & 3.2 & 4.8 & .1 & .1 & .1 & .1 & .1 & .8 & 3.2 \\
\hline IN-W117 & 2.9 & 4.4 & .1 & .1 & 1 & .1 & .1 & .7 & 2.9 \\
\hline IN-W119 & 7.3 & 10.5 & .4 & .4 & .4 & .4 & .4 & 2.1 & 6.3 \\
\hline $\mathrm{IN}-\mathrm{W} 120$ & 8.4 & 12.6 & .4 & .4 & 4 & .4 & .4 & 2.1 & 8.4 \\
\hline IN-W121 & 4.2 & 6.3 & .2 & 2 & .2 & .2 & .2 & 1 & 4.2 \\
\hline N-W122 & 8,000 & 12,000 & 400 & 400 & 400 & 400 & 400 & 2,000 & 8,000 \\
\hline IN-W123 & 100 & 150 & 5 & 5 & 5 & 5 & 5 & 25 & 100 \\
\hline IN-W124 & 20 & 30 & 1 & 1 & 1 & 1 & 1 & 5 & 20 \\
\hline IN-W125 & 10 & 15 & .5 & .5 & .5 & .5 & .5 & 2.5 & 10 \\
\hline IN-W126 & 10.8 & 16.2 & .5 & .5 & .5 & .5 & .5 & 2.7 & 10.8 \\
\hline IT-W004 & 28.3 & 7.3 & 1.7 & 1.4 & 1.4 & 1.4 & 1.4 & & \\
\hline IT-W005 & .9 & 2 & & & & & & & \\
\hline KA-W001 & 8 & 12 & .4 & .4 & .4 & .4 & 4 & 2 & 8 \\
\hline KA-W002 & .4 & .6 & & & & & & .1 & .4 \\
\hline KA-W004 & .2 & .3 & & & & & & & .2 \\
\hline KA-W007 & 8 & 12 & & .5 & .5 & .5 & .5 & 2 & 8 \\
\hline KA-W008 & 2.8 & 4.2 & .1 & .1 & .1 & .1 & .1 & .7 & 2.8 \\
\hline KA-W009 & 10 & 15 & & .6 & .6 & .6 & .6 & 2.5 & 10 \\
\hline KA-W010 & 2 & 3 & & .1 & .1 & .1 & .1 & .5 & 2 \\
\hline
\end{tabular}




\begin{tabular}{|c|c|c|c|c|c|c|c|c|c|}
\hline $\begin{array}{l}\text { Unique } \\
\text { Identifier }\end{array}$ & 20 Year & $\begin{array}{l}\text { Calcu- } \\
\text { lated } \\
\text { Proj. }\end{array}$ & 1993 & 1994 & 1995 & 1996 & 1997 & $\begin{array}{l}1990 \\
2002\end{array}$ & $\begin{array}{l}2003- \\
2022\end{array}$ \\
\hline KA-W011 & 3.8 & 5.8 & & .2 & .2 & .2 & .2 & 1 & 4 \\
\hline KA-W012 & 1.6 & 2.4 & & .1 & .1 & .1 & .1 & .4 & 1.6 \\
\hline KA-W013 & 1.6 & 2.4 & & .1 & .1 & .1 & .1 & .4 & 1.6 \\
\hline KA-W014 & 1.6 & 2.4 & & .1 & .1 & .1 & .1 & .4 & 1.6 \\
\hline KA-W015 & 67.2 & 100.8 & & 4.2 & 4.2 & 4.2 & 4.2 & 16.8 & 67.2 \\
\hline KA-W016 & .7 & 1 & & & & & & .1 & .7 \\
\hline KK-W002 & .4 & .6 & & & & & & .1 & .4 \\
\hline KK-W003 & 4 & 6 & & .2 & .2 & .2 & .2 & 1 & 4 \\
\hline KK-W004 & 5.2 & 7.8 & & 3 & .3 & .3 & .3 & 1.3 & 5.2 \\
\hline KK-W005 & 14 & 21 & .3 & .8 & .8 & .8 & .8 & 3.5 & 14 \\
\hline KK-W006 & 2.2 & 3.3 & & .1 & .1 & .1 & .1 & .5 & 2.2 \\
\hline KK-W007 & 2 & 3 & & .1 & .1 & .1 & .1 & .5 & 2 \\
\hline KK-W008 & 16.8 & 25.2 & & 1 & 1 & 1.2 & 1 & 4.2 & 16.8 \\
\hline KK-W009 & 1.6 & 2.4 & & .1 & .1 & .1 & .1 & .4 & 1.6 \\
\hline KK-W010 & 4 & 6 & & .3 & .2 & 3 & .2 & 1 & 4 \\
\hline KK-W011 & 1.6 & 2.4 & & .1 & .1 & .1 & .1 & .4 & 1.6 \\
\hline KK-W012 & 4 & 6 & & .2 & .2 & .2 & .2 & 1 & 4 \\
\hline KK-W013 & 79.8 & 121.8 & & 4.2 & 4.2 & 4.2 & 4.2 & 21 & 84 \\
\hline KW-W003 & 5.2 & 6 & & .5 & .5 & .2 & .2 & 3 & 1.5 \\
\hline KW-W004 & 11.6 & 13.3 & & 1.5 & 1.5 & .2 & .2 & 6.5 & 3.4 \\
\hline KW-W005 & .5 & .6 & & & & & & .2 & .2 \\
\hline KW-W006 & 4 & 4.8 & & .5 & .5 & .3 & .3 & 1.6 & 1.6 \\
\hline KW-W009 & 12.6 & 16.8 & & & 4.2 & & & 4.2 & 8.4 \\
\hline LA-W001 & 111.4 & 167.1 & 5.5 & 5.5 & 5.5 & 5.5 & 5.5 & 27.8 & 111.4 \\
\hline LA-W002 & 23.5 & 35.3 & 1.1 & 1.1 & 1.1 & 1.1 & 1.1 & 5.8 & 23.6 \\
\hline LA-W003 & 1.3 & 2 & & & & & & 3 & 1.3 \\
\hline LA-W004 & 39.1 & 58.7 & 1.9 & 1.9 & 1.9 & 1.9 & 1.9 & 9.7 & 39.1 \\
\hline LA-W005 & 19.4 & 29.1 & .9 & .9 & .9 & .9 & .9 & 4.8 & 19.4 \\
\hline LA-W006 & 2.7 & 4.1 & .1 & .1 & .1 & .1 & .1 & .6 & 2.7 \\
\hline LA-W007 & 972.6 & $1,458.9$ & 48.6 & 48.6 & 48.6 & 48.6 & 48.6 & 243.1 & 972.6 \\
\hline LA-W008 & 9.9 & 14.9 & .5 & .5 & .5 & .5 & .5 & 2.4 & 9.9 \\
\hline LA-W010 & 113 & 169.6 & 5.6 & 5.6 & 5.6 & 5.6 & 5.6 & 28.2 & 113 \\
\hline LA-W011 & 12.1 & 18.2 & .6 & .6 & .6 & .6 & .6 & 3 & 12.1 \\
\hline LA-W012 & 351 & 526.5 & 17.5 & 17.5 & 17.5 & 17.5 & 17.5 & 87.7 & 351 \\
\hline LA-W013 & 26.2 & 39.3 & 1.3 & 1.3 & 1.3 & 1.3 & 1.3 & 6.5 & 26.2 \\
\hline LA-W014 & 9.3 & 14 & .4 & .4 & .4 & .4 & .4 & 2.3 & 9.3 \\
\hline LA-W015 & 12.3 & 18.4 & .6 & .6 & .6 & .6 & .6 & 3 & 12.3 \\
\hline LA-W016 & 2.5 & 3.8 & .1 & .1 & .1 & .1 & .1 & .6 & 2.5 \\
\hline LA-W017 & 16.1 & 24.1 & .8 & .8 & .8 & .8 & .8 & 4 & 16.1 \\
\hline LA-W018 & .7 & 1.1 & & & & & & .1 & .7 \\
\hline LA-W019 & 3 & 4.5 & .1 & .1 & .1 & .1 & .1 & .7 & 3 \\
\hline LA-W020 & 46 & 69.1 & 2.3 & 2.3 & 2.3 & 2.3 & 2.3 & 11.5 & 46.1 \\
\hline LA-W021 & 44.5 & 66.8 & 2.2 & 2.2 & 2.2 & 2.2 & 2.2 & 11.1 & 44.5 \\
\hline LA-W022 & 2.9 & 4.4 & .1 & .1 & .1 & 1 & .1 & .7 & 2.9 \\
\hline LA-W023 & 3.1 & 4.7 & .1 & .1 & .1 & .1 & .1 & .7 & 3.1 \\
\hline LA-W024 & 53.3 & 80 & 2.6 & 2.6 & 2.6 & 2.6 & 2.6 & 13.3 & 53.3 \\
\hline LA-W025 & 73.9 & 110.9 & 3.7 & 3.7 & 3.7 & 3.7 & 3.7 & 18.4 & 73.9 \\
\hline
\end{tabular}




\begin{tabular}{|c|c|c|c|c|c|c|c|c|c|}
\hline $\begin{array}{l}\text { Unique } \\
\text { Identifier }\end{array}$ & 20 Year & $\begin{array}{l}\text { Calcu- } \\
\text { lated } \\
\text { Proj. }\end{array}$ & 1993 & 1994 & 1995 & 1996 & 1997 & $\begin{array}{l}1990 . \\
2002\end{array}$ & $\begin{array}{l}2003- \\
2022\end{array}$ \\
\hline LA-W026 & 84.7 & 126.9 & 4.2 & 4.2 & 4.2 & 4.2 & 4.2 & 21.6 & 84.2 \\
\hline LA-W027 & 62.6 & 93.9 & 3.1 & 3.1 & 3.1 & 3.1 & 3.1 & 15.6 & 62.6 \\
\hline \multicolumn{10}{|l|}{ LA-W028 } \\
\hline LA-W029 & .1 & .1 & & & & & & & .1 \\
\hline LA-W030 & 5.5 & 8.3 & .2 & .2 & .2 & .2 & .2 & 1.3 & 5.5 \\
\hline \multicolumn{10}{|l|}{ LA-W031 } \\
\hline \multicolumn{10}{|l|}{ LA-W032 } \\
\hline LA-W033 & 13 & 19.5 & .6 & .6 & .6 & .6 & .6 & 3.2 & 13 \\
\hline LA-W034 & 12.2 & 18.3 & .6 & .6 & .6 & .6 & .6 & 3 & 12.2 \\
\hline LA-W036 & 1.3 & 2 & & & & & & .3 & 1.3 \\
\hline LA-W037 & $1,215.8$ & $1,823.7$ & 60.7 & 60.7 & 60.7 & 60.7 & 60.7 & 303.9 & $1,215.8$ \\
\hline LA-W038 & 84.9 & 127.4 & 4.2 & 4.2 & 4.2 & 4.2 & 4.2 & 21.2 & 84.9 \\
\hline LA-W039 & 955.4 & $1,433.1$ & 47.7 & 47.7 & 47.7 & 47.7 & 47.7 & 238.8 & 955.4 \\
\hline LA-W040 & 153.1 & 229.7 & 7.6 & 7.6 & 7.6 & 7.6 & 7.6 & 38.2 & 153.1 \\
\hline LB-W002 & 10 & 15 & .5 & .5 & .5 & .5 & .5 & 2.5 & 10 \\
\hline LB-W005 & 8 & 12 & .4 & .4 & .4 & 4 & .4 & 2 & 8 \\
\hline LB-W007 & 4 & 6 & .2 & .2 & .2 & .2 & .2 & 1 & 4 \\
\hline LB-W010 & 162.5 & 175 & 25 & 25 & 25 & 25 & 25 & 25 & 25 \\
\hline LB-W011 & .8 & 1.2 & & & & & & .2 & .8 \\
\hline LB-W012 & 80 & 120 & 4 & 4 & 4 & 4 & 4 & 20 & 80 \\
\hline LL-W001 & 55.5 & 84 & 3 & 3 & 3 & 3 & 3 & 12 & 57 \\
\hline LL-W002 & 703 & 1,064 & 38 & 38 & 38 & 38 & 38 & 152 & 722 \\
\hline LL-W003 & 7.4 & 11.2 & .4 & .4 & .4 & .4 & .4 & 1.6 & 7.6 \\
\hline LL-W004 & 462.5 & 700 & 25 & 25 & 25 & 25 & 25 & 100 & 475 \\
\hline LL-W005 & 74 & 112 & 4 & 4 & 4 & 4 & 4 & 16 & 76 \\
\hline LL-W006 & 111 & 168 & 6 & 6 & 6 & 6 & 6 & 24 & 114 \\
\hline LL-W007 & 60.7 & 81 & 4.5 & 4.5 & 4.5 & 4.5 & 4.5 & 18 & 40.5 \\
\hline LL-W008 & 185 & 280 & 10 & 10 & 10 & 10 & 10 & 40 & 190 \\
\hline LL-W009 & 925 & 1,400 & 50 & 50 & 50 & 50 & 50 & 200 & 950 \\
\hline LL-W010 & 74 & 112 & 4 & 4 & 4 & 4 & 4 & 16 & 76 \\
\hline LL-W011 & 9.2 & 14 & .5 & .5 & .5 & .5 & .5 & 2 & 9.5 \\
\hline LL-W014 & 111 & 168 & 6 & 6 & 6 & 6 & 6 & 24 & 114 \\
\hline LL-W015 & 55.5 & 84 & 3 & 3 & 3 & 3 & 3 & 12 & 57 \\
\hline LL-W016 & 33.3 & 50.4 & 1.8 & 1.8 & 1.8 & 1.8 & 1.8 & 7.2 & 34.2 \\
\hline LL-W017 & 462.5 & 700 & 25 & 25 & 25 & 25 & 25 & 100 & 475 \\
\hline LL-W018 & 18.5 & 28 & 1 & 1 & 1 & 1 & 1 & 4 & 19 \\
\hline LL-W019 & 5.5 & 8.4 & .3 & .3 & .3 & .3 & .3 & 1.2 & 5.7 \\
\hline LL-W020 & 11.1 & 16.8 & .6 & .6 & .6 & .6 & .6 & 2.4 & 11.4 \\
\hline LL-W021 & 5.5 & 8.4 & .3 & .3 & .3 & .3 & .3 & 1.2 & 5.7 \\
\hline LL-W022 & 55.5 & 84 & 3 & 3 & 3 & 3 & 3 & 12 & 57 \\
\hline LL-W023 & 3.7 & 5.6 & .2 & .2 & .2 & .2 & .2 & .8 & 3.8 \\
\hline LL-W025 & 555 & 840 & 30 & 30 & 30 & 30 & 30 & 120 & 570 \\
\hline LL-W026 & 5.5 & 8.4 & .3 & .3 & .3 & .3 & .3 & 1.2 & 5.7 \\
\hline NN-W001 & 4 & 6 & & .2 & .2 & .2 & .2 & 1 & 4 \\
\hline NN-W002 & 2 & 3 & & .1 & .1 & .1 & .1 & .5 & 2 \\
\hline OR-W039 & 1,160 & 1,740 & 58 & 58 & 58 & 58 & 58 & 290 & 1,160 \\
\hline OR-W040 & 132 & 198 & 6.6 & 6.6 & 6.6 & 6.6 & 6.6 & 33 & 132 \\
\hline
\end{tabular}




\begin{tabular}{|c|c|c|c|c|c|c|c|c|c|}
\hline $\begin{array}{l}\text { Unique } \\
\text { Identifier }\end{array}$ & 20 Year & $\begin{array}{l}\text { Calcu- } \\
\text { lated } \\
\text { Proj }\end{array}$ & 1993 & 1994 & 1995 & 1996 & 1997 & $\begin{array}{l}1990 . \\
2002\end{array}$ & $\begin{array}{l}2003- \\
2022\end{array}$ \\
\hline OR-W044 & 182 & 273 & 9.1 & 9.1 & 9.1 & 9.1 & 9.1 & 45.5 & 182 \\
\hline OR-W046 & 120 & 180 & 6 & 6 & 6 & 6 & 6 & 30 & 120 \\
\hline PH-W003 & 2 & .5 & .1 & .1 & .1 & 1 & .1 & & \\
\hline PH-W004 & 1 & .2 & & & & & & & \\
\hline PH-W007 & .5 & .1 & & & & & & & \\
\hline PN-W002 & .8 & 1.2 & & & & & & .2 & .8 \\
\hline PO-W001 & 42 & 63 & 2.1 & 2.1 & 2.1 & 2.1 & 2.1 & 10.5 & 42 \\
\hline $\mathrm{PO}-\mathrm{W} 003$ & 12.6 & 18.9 & .6 & .6 & .6 & .6 & .6 & 3.1 & 12.6 \\
\hline PO-W004 & 1,880 & 2,820 & 94 & 94 & 94 & 94 & 94 & 470 & 1,880 \\
\hline PO-W005 & 4.2 & 6.3 & .2 & .2 & .2 & .2 & .2 & 1 & 4.2 \\
\hline PO-W006 & 4.2 & 6.3 & .2 & .2 & .2 & .2 & .2 & 1 & 4.2 \\
\hline PO-W007 & 56 & 84 & 2.8 & 2.8 & 2.8 & 2.8 & 2.8 & 14 & 56 \\
\hline PO-W008 & 300 & 450 & 15 & 15 & 15 & 15 & 15 & 75 & 300 \\
\hline PO-W009 & 32 & 48 & 1.6 & 1.6 & 1.6 & 1.6 & 1.6 & 8 & 32 \\
\hline PO-W010 & 8.4 & 12.6 & .4 & .4 & .4 & .4 & .4 & 2.1 & 8.4 \\
\hline PO-W011 & 3.6 & 5.4 & .1 & 1 & .1 & .1 & .1 & .9 & 3.6 \\
\hline PO-W012 & 4.2 & 6.3 & .2 & 2 & .2 & .2 & .2 & 1 & 4.2 \\
\hline PO-W015 & 300 & 450 & 15 & 15 & 15 & 15 & 15 & 75 & 300 \\
\hline PO-W016 & 300 & 450 & 15 & 15 & 15 & 15 & 15 & 75 & 300 \\
\hline PO-W017 & 126 & 189 & 6.3 & 6.3 & 6.3 & 6.3 & 6.3 & 31.5 & 126 \\
\hline PO-W018 & 168 & 252 & 8.4 & 8.4 & 8.4 & 8.4 & 8.4 & 42 & 168 \\
\hline PO-W019 & 420 & 630 & 21 & 21 & 21 & 21 & 21 & 105 & 420 \\
\hline PO-W020 & 100 & 150 & 5 & 5 & 5 & 5 & 5 & 25 & 100 \\
\hline PO-W021 & 20 & 30 & 1 & 1 & 1 & 1 & 1 & 5 & 20 \\
\hline PO-W022 & 48 & 72 & 2.4 & 2.4 & 2.4 & 2.4 & 2.4 & 12 & 48 \\
\hline PO-W024 & 300 & 450 & 15 & 15 & 15 & 15 & 15 & 75 & 300 \\
\hline PO-W025 & 2 & 3 & .1 & .1 & .1 & .1 & .1 & .5 & 2 \\
\hline PO-W026 & 54 & 81 & 2.7 & 2.7 & 2.7 & 2.7 & 2.7 & 13.5 & 54 \\
\hline PO-W028 & 16.8 & 25.2 & .8 & .8 & .8 & .8 & .8 & 4.2 & 16.8 \\
\hline PO-W029 & 52 & 78 & 2.6 & 2.6 & 2.6 & 2.6 & 2.6 & 13 & 52 \\
\hline PO-W030 & 2 & 3 & .1 & .1 & .1 & .1 & .1 & .5 & 2 \\
\hline PO-W031 & 5.8 & 8.7 & .2 & .2 & .2 & .2 & .2 & 1.4 & 5.8 \\
\hline PO-W032 & 7.2 & 10.8 & .3 & .3 & .3 & .3 & .3 & 1.8 & 7.2 \\
\hline PO-W033 & 230 & 345 & 11.5 & 11.5 & 11.5 & 11.5 & 11.5 & 57.5 & 230 \\
\hline PO-W034 & .6 & .9 & & & & & & .1 & .6 \\
\hline PO-W035 & 52 & 78 & 2.6 & 2.6 & 2.6 & 2.6 & 2.6 & 13 & 52 \\
\hline PO-W036 & 10.8 & 16.2 & .5 & .5 & .5 & .5 & .5 & 2.7 & 10.8 \\
\hline PO-W037 & 8.4 & 12.6 & .4 & .4 & .4 & .4 & 4 & 2.1 & 8.4 \\
\hline PO-W038 & 102 & 153 & 5.1 & 5.1 & 5.1 & 5.1 & 5.1 & 25.5 & 102 \\
\hline PO-W039 & 400 & 600 & 20 & 20 & 20 & 20 & 20 & 100 & 400 \\
\hline PO-W041 & 14 & 21 & .7 & .7 & .7 & .7 & .7 & 3.5 & 14 \\
\hline PO-W042 & 204 & 300 & 12 & 12 & 12 & 12 & 12 & 48 & 192 \\
\hline PO-W043 & 12.8 & 19.2 & .6 & .6 & .6 & .6 & .6 & 3.2 & 12.8 \\
\hline PO-W044 & 102 & 153 & 5.1 & 5.1 & 5.1 & 5.1 & 5.1 & 25.5 & 102 \\
\hline PO-W045 & 40 & 60 & 2 & 2 & 2 & 2 & 2 & 10 & 40 \\
\hline PO-W046 & 7 & 10 & .5 & .5 & .5 & .5 & .5 & 1.5 & 6 \\
\hline PO-W047 & 60 & 90 & 3 & 3 & 3 & 3 & 3 & 15 & 60 \\
\hline
\end{tabular}




\begin{tabular}{|c|c|c|c|c|c|c|c|c|c|}
\hline $\begin{array}{l}\text { Unique } \\
\text { Iaenifier }\end{array}$ & 20 Y ear & $\begin{array}{l}\text { Calou } \\
\text { laled } \\
\text { Prot }\end{array}$ & 1993 & 1994 & 1995 & 1996 & 1997 & $\begin{array}{l}1990^{\circ} \\
2002\end{array}$ & $\begin{array}{l}2003- \\
2022\end{array}$ \\
\hline PO-W048 & 50 & 75 & 2.5 & 2.5 & 2.5 & 2.5 & 2.5 & 12.5 & 50 \\
\hline PO-W049 & .4 & .6 & & & & & & .1 & .4 \\
\hline PO-W050 & 334 & 501 & 16.7 & 16.7 & 16.7 & 16.7 & 16.7 & 83.5 & 334 \\
\hline PO-W051 & 12.6 & 18.9 & .6 & .6 & .6 & .6 & .6 & 3.1 & 12.6 \\
\hline PO-W052 & 6,000 & 9,000 & 300 & 300 & 300 & 300 & 300 & 1,500 & 6,000 \\
\hline PO-W053 & 50 & 75 & 2.5 & 2.5 & 2.5 & 2.5 & 2.5 & 12.5 & 50 \\
\hline PO-W055 & 120 & 180 & 6 & 6 & 6 & 6 & 6 & 30 & 120 \\
\hline PO-W057 & 74 & 111 & 3.7 & 3.7 & 3.7 & 3.7 & 3.7 & 18.5 & 74 \\
\hline PO-W058 & 420 & 630 & 21 & 21 & 21 & 21 & 21 & 105 & 420 \\
\hline PO-W059 & 2 & 3 & .1 & .1 & .1 & .1 & .1 & .5 & 2 \\
\hline PO-W060 & 11,285 & 16,585 & 360 & 625 & 625 & 625 & 625 & 3,125 & 10,600 \\
\hline PO-W061 & 40 & 60 & 2 & 2 & 2 & 2 & 2 & 10 & 40 \\
\hline PO-W064 & 25 & 37.5 & 1.2 & 1.2 & 1.2 & 1.2 & 1.2 & 6.2 & 25 \\
\hline PO-W065 & 20 & 30 & 1 & 1 & 1 & 1 & 1 & 5 & 20 \\
\hline PO-W066 & 48 & 72 & 2.4 & 2.4 & 2.4 & 2.4 & 2.4 & 12 & 48 \\
\hline PO-W067 & 4.2 & 6.3 & .2 & .2 & .2 & .2 & .2 & 1 & 4.2 \\
\hline PO-W068 & 46 & 69 & 2.3 & 2.3 & 2.3 & 2.3 & 2.3 & 11.5 & 46 \\
\hline PO-W069 & 780 & 1,170 & 39 & 39 & 39 & 39 & 39 & 195 & 780 \\
\hline PO-W070 & 2 & 3 & .1 & .1 & .1 & .1 & .1 & .5 & 2 \\
\hline PO-W071 & 6.8 & 10.2 & .3 & .3 & 3 & .3 & .3 & 1.7 & 6.8 \\
\hline PO-W072 & 20 & 30 & 1 & 1 & 1 & 1 & 1 & 5 & 20 \\
\hline PO-W073 & 50 & 75 & 2.5 & 2.5 & 2.5 & 2.5 & 2.5 & 12.5 & 50 \\
\hline PO-W074 & 2 & 3 & .1 & .1 & .1 & .1 & .1 & .5 & 2 \\
\hline PO-W075 & 1 & 1.5 & & & & & & .2 & 1 \\
\hline PO-W076 & .6 & .9 & & & & & & .1 & .6 \\
\hline PO-W077 & 36 & 54 & 1.8 & 1.8 & 1.8 & 1.8 & 1.8 & 9 & 36 \\
\hline PO-W078 & 124 & 186 & 6.2 & 6.2 & 6.2 & 6.2 & 6.2 & 31 & 124 \\
\hline PO-W079 & 6.4 & 9.6 & .3 & .3 & .3 & .3 & .3 & 1.6 & 6.4 \\
\hline PO-W080 & 20 & 30 & 1 & 1 & 1 & 1 & 1 & 5 & 20 \\
\hline PO-W081 & 4.2 & 6.3 & .2 & .2 & .2 & .2 & .2 & 1 & 4.2 \\
\hline PS-W001 & 71.3 & 15.8 & 1 & 3.7 & 3.7 & 3.7 & 3.7 & & \\
\hline PS-W002 & 17.5 & 3.7 & & .9 & .9 & .9 & .9 & & \\
\hline PS-W003 & 17.5 & 3.7 & & 9 & .9 & .9 & .9 & & \\
\hline PS-W005 & 17.5 & 3.7 & & .9 & .9 & .9 & .9 & & \\
\hline PS-W007 & 34.2 & 7.2 & & 1.8 & 1.8 & 1.8 & 1.8 & & \\
\hline PS-W012 & 9.5 & 2 & & .5 & .5 & .5 & .5 & & \\
\hline PX-W010 & .8 & .8 & .1 & .1 & .1 & .1 & .1 & .2 & .1 \\
\hline PX-W021 & 198 & 213 & 24.6 & 24.6 & 24.6 & 24.6 & 24.6 & 60 & 30 \\
\hline PX-W022 & 15.5 & 16.7 & 1.9 & 1.9 & 1.9 & 1.9 & 1.9 & 4.8 & 2.4 \\
\hline PX-W023 & 159.1 & 171.1 & 19.6 & 19.6 & 19.6 & 19.6 & 19.6 & 49 & 24 \\
\hline PX-W024 & 10.9 & 11.8 & 1.3 & 1.3 & 1.3 & 1.3 & 1.3 & 3.4 & 1.7 \\
\hline PX-W025 & 72 & 77.5 & 8.9 & 8.9 & 8.9 & 8.9 & 8.9 & 22 & 11 \\
\hline PX-W026 & 4.9 & 5.3 & .6 & .6 & .6 & .6 & .6 & 1.5 & .8 \\
\hline PX-W027 & 21 & 22.6 & 2.5 & 2.5 & 2.5 & 2.5 & 2.5 & 6.5 & 3.2 \\
\hline PX-W028 & 16.2 & 17.5 & 2 & 2 & 2 & 2 & 2 & 5 & 2.5 \\
\hline PX-W029 & 6.7 & 7.2 & .8 & .8 & .8 & .8 & .8 & 2 & 1 \\
\hline PX-W030 & 1.4 & 1.5 & .1 & .1 & .1 & .1 & .1 & .4 & .2 \\
\hline
\end{tabular}




\begin{tabular}{|c|c|c|c|c|c|c|c|c|c|}
\hline $\begin{array}{l}\text { Unique } \\
\text { Identfier }\end{array}$ & 20 Year & $\begin{array}{l}\text { Calcu- } \\
\text { lated } \\
\text { Proj. }\end{array}$ & 1993 & 1994 & 1995 & 1996 & 1997 & $\begin{array}{l}1990 \\
2002\end{array}$ & $\begin{array}{l}2003^{-} \\
2022\end{array}$ \\
\hline PX-W032 & 3.2 & 3.4 & .4 & .4 & .4 & .4 & .4 & 1 & .4 \\
\hline PX-W033 & 1.4 & 1.5 & .1 & 1 & 1 & .1 & .1 & .4 & .2 \\
\hline PX-W034 & 25.1 & 27 & 3.1 & 3.1 & 3.1 & 3.1 & 3.1 & 7.7 & 3.8 \\
\hline PX-W035 & 12 & 12.9 & 1.5 & 1.5 & 1.5 & 1.5 & 1.5 & 3.6 & 1.8 \\
\hline PX-W036 & 1.3 & 1.4 & .1 & .1 & .1 & .1 & .1 & .4 & .2 \\
\hline PX-W037 & 1.4 & 1.5 & .1 & .1 & .1 & .1 & .1 & .4 & .2 \\
\hline PX-W038 & 1.6 & 1.7 & .2 & .2 & .2 & .2 & .2 & .5 & .2 \\
\hline PX-W039 & 1.5 & 1.6 & .1 & .1 & .1 & .1 & .1 & .4 & .2 \\
\hline PX-W040 & 1.4 & 1.5 & .1 & .1 & .1 & .1 & .1 & .4 & .2 \\
\hline RF-W005 & 160 & 40 & 8 & 8 & 8 & 8 & 8 & & \\
\hline RF-W006 & $1,052.4$ & 263.1 & 52.6 & 52.6 & 52.6 & 52.6 & 52.6 & & \\
\hline RF-W009 & 356 & 89 & 17.8 & 17.8 & 17.8 & 17.8 & 17.8 & & \\
\hline RF-W010 & 56 & 14 & 2.8 & 2.8 & 2.8 & 2.8 & 2.8 & & \\
\hline RF-W011 & 179 & 44.7 & 8.9 & 8.9 & 8.9 & 8.9 & 8.9 & & \\
\hline RF-W012 & 497.6 & 124.4 & 24.8 & 24.8 & 24.8 & 24.8 & 24.8 & & \\
\hline RF-W013 & 38 & 9.5 & 1.9 & 1.9 & 1.9 & 1.9 & 1.9 & & \\
\hline RF-W018 & $1,036.8$ & 259.2 & 51.8 & 51.8 & 51.8 & 51.8 & 51.8 & & \\
\hline RF-W019 & 6,980 & 1,745 & 349 & 349 & 349 & 349 & 349 & & \\
\hline RF-W020 & 2.8 & .7 & .1 & .1 & .1 & .1 & .1 & & \\
\hline RF-W023 & 35.8 & 8.9 & 1.7 & 1.7 & 1.7 & 1.7 & 1.7 & & \\
\hline RF-W024 & 38.6 & 9.6 & 1.9 & 1.9 & 1.9 & 1.9 & 1.9 & & \\
\hline RF-W028 & 12.4 & 3.1 & .6 & .6 & .6 & .6 & .6 & & \\
\hline RF-W029 & 47.6 & 11.9 & 2.3 & 2.3 & 2.3 & 2.3 & 2.3 & & \\
\hline RF-W030 & 11.2 & 2.8 & .5 & .5 & .5 & .5 & .5 & & \\
\hline RF-W032 & 23.4 & 5.8 & 1.1 & 1.1 & 1.1 & 1.1 & 1.1 & & \\
\hline RF-W035 & 42.2 & 10.5 & 2.1 & 2.1 & 2.1 & 2.1 & 2.1 & & \\
\hline RF-W036 & 4.2 & 1 & .2 & .2 & .2 & .2 & .2 & & \\
\hline RF-W038 & 105 & 26.2 & 5.2 & 5.2 & 5.2 & 5.2 & 5.2 & & \\
\hline RF-W041 & 37.4 & 9.3 & 1.8 & 1.8 & 1.8 & 1.8 & 1.8 & & \\
\hline RF-W043 & 17.8 & 4.4 & .8 & .8 & .8 & .8 & .8 & & \\
\hline RF-W045 & 11 & 2.7 & .5 & .5 & .5 & .5 & .5 & & \\
\hline RF-W046 & 11.2 & 2.8 & .5 & .5 & .5 & .5 & .5 & & \\
\hline RF-W047 & 12.4 & 3.1 & .6 & .6 & .6 & .6 & .6 & & \\
\hline RF-W050 & 1,150 & 287.5 & 57.5 & 57.5 & 57.5 & 57.5 & 57.5 & & \\
\hline RF-W051 & 180 & 45 & 9 & 9 & 9 & 9 & 9 & & \\
\hline RF-W055 & 42 & 10.5 & 2.1 & 2.1 & 2.1 & 2.1 & 2.1 & & \\
\hline RF-W057 & 14 & 3.5 & .7 & .7 & .7 & .7 & .7 & & \\
\hline RF-W062 & 7 & 1.7 & .3 & .3 & .3 & .3 & .3 & & \\
\hline RF-W063 & 22 & 5.5 & 1.1 & 1.1 & 1.1 & 1.1 & 1.1 & & \\
\hline RF-W064 & 2,000 & 500 & 100 & 100 & 100 & 100 & 100 & & \\
\hline RF-W066 & 66.8 & 16.7 & 3.3 & 3.3 & 3.3 & 3.3 & 3.3 & & \\
\hline RF-W067 & 18.6 & 4.6 & .9 & .9 & .9 & .9 & .9 & & \\
\hline RF-W074 & 36.4 & 9.1 & 1.8 & 1.8 & 1.8 & 1.8 & 1.8 & & \\
\hline RF-W075 & 91.2 & 22.8 & 4.5 & 4.5 & 4.5 & 4.5 & 4.5 & & \\
\hline RF-W079 & 200 & 50 & 10 & 10 & 10 & 10 & 10 & & \\
\hline RL-W009 & 282302 & 78,512 & 8,229 & 18,817 & 20,384 & 17,496 & 13,586 & & \\
\hline RL-W010 & 41,446 & 26,116 & 12,086 & & 10,177 & 2,831 & 1,022 & & \\
\hline
\end{tabular}




\begin{tabular}{|c|c|c|c|c|c|c|c|c|c|}
\hline $\begin{array}{l}\text { Unique } \\
\text { Identifier }\end{array}$ & 20 Year & $\begin{array}{l}\text { Calcu- } \\
\text { lated } \\
\text { Proj. }\end{array}$ & 1993 & 1994 & 1995 & 1996 & 1997 & $\begin{array}{l}1990- \\
2002\end{array}$ & $\begin{array}{l}2003 \\
2022\end{array}$ \\
\hline RL-W017 & 28.5 & 44 & .3 & 3 & 1.4 & 1.5 & 1.5 & 7.7 & 31 \\
\hline RL-W018 & 305.6 & 469.8 & 3.9 & 3.8 & 16.2 & 17.1 & 17.1 & 83.2 & 328.2 \\
\hline RL-W019 & 44.7 & 68.7 & .5 & .5 & 2.3 & 2.5 & 2.5 & 12.1 & 48 \\
\hline RL-W020 & $1,035.3$ & $1,591.3$ & 13.4 & 12.9 & 54.9 & 58 & 58 & 282 & $1,111.8$ \\
\hline RL-W021 & 13.7 & 21.2 & .1 & .1 & .7 & .7 & .7 & 3.7 & 14.8 \\
\hline RL-W022 & 891.4 & 1,370 & 11.5 & 11.1 & 47.2 & 49.9 & 50 & 242.8 & 957.2 \\
\hline RL-W023 & 92.1 & 127.3 & 5.5 & 4.7 & 5.1 & 6.8 & 7.5 & 26.9 & 70.4 \\
\hline RL-W024 & 22.2 & 30.8 & 1.3 & 1.1 & 1.2 & 1.6 & 1.8 & 6.5 & 17 \\
\hline RL-W025 & 16 & 22.1 & .9 & .8 & .9 & 1.2 & 1.3 & 4.7 & 12.2 \\
\hline RL-W026 & 28.6 & 39.6 & 1.7 & 1.4 & 1.6 & 2.1 & 2.3 & 8.4 & 21.9 \\
\hline RL-W027 & 63.7 & 88.1 & 3.8 & 3.3 & 3.5 & 4.7 & 5.1 & 18.6 & 48.8 \\
\hline RL-W028 & 18.9 & 26.2 & 1.1 & .9 & 1 & 1.4 & 1.5 & 5.5 & 14.5 \\
\hline RL-W029 & 211.7 & 292.7 & 12.8 & 10.9 & 11.9 & 15.7 & 17.2 & 62 & 162 \\
\hline RL-W030 & 81.6 & 112.9 & 4.9 & 4.2 & 4.5 & 6 & 6.6 & 23.9 & 62.4 \\
\hline RL-W031 & 252.2 & 371.4 & 12.7 & 11.9 & 13.5 & 15.8 & 9.1 & 69.7 & 238.4 \\
\hline RL-W032 & 18.7 & 25.9 & 1.1 & .9 & 1 & 1.4 & 1.5 & 5.5 & 14.3 \\
\hline RL-W033 & 4.1 & 5.7 & .2 & 2 & .2 & .3 & .3 & 1.2 & 3.2 \\
\hline RL-W034 & 67.7 & 104 & 8 & .8 & 3.5 & 3.7 & 3.8 & 18.4 & 72.7 \\
\hline RL-W035 & 301.7 & 461.5 & 22.8 & 15.8 & 12.9 & 11.9 & 11.9 & 66.5 & 319.6 \\
\hline $\mathrm{RL}-\mathrm{W} 036$ & 151.3 & 222.8 & 7.6 & 7.1 & 8.1 & 9.4 & 5.5 & 41.8 & 143 \\
\hline RL-W037 & 95.3 & 146.5 & 1.2 & 1.2 & 5 & 5.3 & 5.3 & 25.9 & 102.3 \\
\hline RL-W038 & 1.3 & 2 & & & & & & .3 & 1.4 \\
\hline RL-W039 & 745.4 & $1,145.7$ & 9.6 & 9.3 & 39.5 & 41.7 & 41.8 & 203 & 800.5 \\
\hline RL-W040 & $1,449.5$ & $2,227.8$ & 18.8 & 18.1 & 76.8 & 81.2 & 81.3 & 394.8 & $1,556.6$ \\
\hline RL-W041 & 79.2 & 109.5 & 4.8 & 4.1 & 4.4 & 5.9 & 6.4 & 23.2 & 60.6 \\
\hline RL-W042 & 344.4 & 529.4 & 4.4 & 4.3 & 18.2 & 19.3 & 19.3 & 93.8 & 369.9 \\
\hline RL-W043 & 777.6 & $1,195.2$ & 10.1 & 9.7 & 41.2 & 43.5 & 43.6 & 211.8 & 835.1 \\
\hline RL-W044 & 44.7 & 68.7 & .5 & .5 & 2.3 & 2.5 & 2.5 & 12.1 & 48 \\
\hline RL-W045 & 13.7 & 21.2 & 1 & .1 & .7 & .7 & .7 & 3.7 & 14.8 \\
\hline RL-W046 & 454.7 & 698.9 & 5.9 & 5.7 & 24.1 & 25.4 & 25.5 & 123.8 & 488.3 \\
\hline RL-W047 & 393.4 & 757.9 & 4.6 & 2.1 & 4 & 4.6 & 4.3 & 8.9 & 729.1 \\
\hline RL-W048 & 344.5 & 663.8 & 4 & 1.9 & 3.5 & 4 & 3.8 & 7.8 & 638.5 \\
\hline RL-W049 & $4,036.9$ & $7,777.9$ & 47.3 & 22.4 & 42 & 47.8 & 44.8 & 91.6 & $7,481.9$ \\
\hline RL-W050 & 105.4 & 203.1 & 1.2 & .5 & 1.1 & 1.2 & 1.1 & 2.3 & 195.3 \\
\hline RL-W051 & 54 & 104 & 6 & .3 & .5 & .6 & .6 & 1.2 & 100 \\
\hline RL-W052 & 107 & 164.4 & 1.3 & 1.3 & 5.6 & 6 & 6 & 29.1 & 114.9 \\
\hline RL-W053 & 1.9 & 3 & & & .1 & .1 & .1 & .5 & 2.1 \\
\hline RL-W054 & 41.4 & 63.6 & .5 & .5 & 2.2 & 2.3 & 2.3 & 11.2 & 44.4 \\
\hline RL-W055 & 77.4 & 107.1 & 4.7 & 4 & 4.3 & 5.7 & 6.3 & 22.7 & 59.2 \\
\hline RL-W056 & 76.3 & 105.5 & 4.6 & 3.9 & 4.2 & 5.6 & 6.2 & 22.3 & 58.4 \\
\hline RL-W057 & $6,560.4$ & 10,105 & 127.4 & 143.3 & 293.2 & 363.4 & 358.8 & $1,729.3$ & $7,089.7$ \\
\hline RL-W058 & 58.9 & 81.4 & 3.5 & 3 & 3.3 & 4.3 & 4.8 & 17.2 & 45.1 \\
\hline RL-W059 & 41.6 & 57.5 & 2.5 & 2.1 & 2.3 & 3.1 & 3.3 & 12.1 & 31.8 \\
\hline RL-W060 & 114.1 & 157.7 & 6.9 & 5.9 & 6.4 & 8.5 & 9.2 & 33.4 & 87.3 \\
\hline RL-W061 & 69 & 106.1 & .9 & .8 & 3.6 & 3.8 & 3.8 & 18.8 & 74.1 \\
\hline RL-W062 & 2.2 & 3.4 & .1 & .1 & .1 & & & .5 & 2.3 \\
\hline RL-W063 & 216.9 & 333.4 & 2.8 & 2.7 & 11.5 & 12.1 & 12.1 & 59 & 232.9 \\
\hline
\end{tabular}




\begin{tabular}{|c|c|c|c|c|c|c|c|c|c|}
\hline $\begin{array}{l}\text { Unique } \\
\text { Identifier }\end{array}$ & 20 Year & $\begin{array}{l}\text { Calcu- } \\
\text { lated } \\
\text { Proil }\end{array}$ & 1993 & 1994 & 1995 & 1996 & 1997 & $\begin{array}{l}1990 . \\
2002\end{array}$ & $\begin{array}{l}2008 \\
2029\end{array}$ \\
\hline RL-W064 & $2,364.6$ & $3,634.2$ & 30.7 & 29.6 & 125.3 & 132.4 & 132.6 & 644 & $2,539.3$ \\
\hline RL-W065 & $1,363.1$ & 2,095 & 17.7 & 17.1 & 72.2 & 76.3 & 76.4 & 371.2 & $1,463.8$ \\
\hline RL-W066 & 541.6 & 832.5 & 7 & 6.8 & 28.7 & 30.3 & 30.3 & 147.5 & 581.7 \\
\hline RL-W067 & 13.7 & 21.2 & .1 & .1 & .7 & .7 & .7 & 3.7 & 14.8 \\
\hline RL-W071 & 5 & 6.6 & & .3 & .4 & .2 & .2 & 2 & 3.1 \\
\hline RL-W072 & 4.1 & 5.4 & & .3 & .3 & .1 & .2 & 1.7 & 2.6 \\
\hline RL-W073 & 34.3 & 45.1 & .4 & 2.4 & 2.9 & 1.4 & 1.9 & 14.2 & 21.6 \\
\hline RL-W074 & 15.8 & 20.7 & .2 & 1.1 & 1.3 & .6 & .9 & 6.5 & 9.9 \\
\hline RL-W075 & 2.4 & 3.2 & & 1 & .2 & .1 & .1 & 1 & 1.5 \\
\hline RL-W076 & 1.6 & 2.1 & & 1 & .1 & & & .6 & 1 \\
\hline RL-W077 & 2.4 & 3.1 & & .1 & .2 & .1 & .1 & 1 & 1.5 \\
\hline RL-W078 & 25.7 & 33.4 & 1 & 1.8 & 2.3 & 1.1 & 1.4 & 11.1 & 15.2 \\
\hline RL-W079 & 17.2 & 22.3 & & 1.2 & 1.5 & .7 & .9 & 7.4 & 10.1 \\
\hline RL-W080 & 1.4 & 1.9 & .9 & & & & & & .9 \\
\hline RL-W081 & .2 & .2 & & & & & & & 1 \\
\hline RL-W084 & 86 & 111.4 & 4 & 6.1 & 7.9 & 3.9 & 4.8 & 37.3 & 50.9 \\
\hline RL-W085 & 1 & 1.4 & & & & & & .4 & .6 \\
\hline RL-W086 & 2.7 & 3.6 & & .2 & .2 & .1 & .1 & 1.1 & 1.7 \\
\hline RL-W087 & 493.7 & 951.2 & 5.7 & 2.7 & 5.1 & 5.8 & 5.4 & 11.2 & 914.9 \\
\hline RL-W089 & 7.2 & 11.1 & & & .3 & .4 & .4 & 1.9 & 7.7 \\
\hline RL-W090 & $1,104.4$ & $1,697.4$ & 14.3 & 13.8 & 58.5 & 61.8 & 61.9 & 300.8 & 1,186 \\
\hline RL-W091 & 13.7 & 21.2 & .1 & .1 & .7 & .7 & .7 & 3.7 & 14.8 \\
\hline RL-W092 & 1.9 & 3 & & & .1 & 1 & 1 & .5 & 2.1 \\
\hline RL-W093 & 125.3 & 173.3 & 7.6 & 6.4 & 7 & 9.3 & 10.2 & 36.7 & 95.9 \\
\hline RL-W094 & 952.2 & $1,463.6$ & 12.3 & 11.9 & 50.4 & 53.3 & 53.4 & 259.3 & $1,022.6$ \\
\hline RL-W095 & 974.9 & $1,498.3$ & 12.6 & 12.2 & 51.6 & 54.6 & 54.6 & 265.5 & $1,046.9$ \\
\hline RL-W097 & 148.1 & 227.7 & 1.9 & 1.8 & 7.8 & 8.3 & 8.3 & 40.3 & 159.1 \\
\hline RL-W098 & $2,023.6$ & $3,898.8$ & 23.7 & 11.2 & 21 & 23.9 & 22.4 & 45.9 & $3,750.5$ \\
\hline RL-W099 & 41.4 & 63.6 & .5 & .5 & 2.2 & 2.3 & 2.3 & 11.2 & 44.4 \\
\hline RL-W100 & 510.5 & 784.6 & 6.6 & 6.4 & 27 & 28.6 & 28.6 & 139 & 548.2 \\
\hline RL-W101 & 117.6 & 169.3 & 4 & 6 & 8 & 6 & 6.6 & 35.3 & 103.3 \\
\hline RL-W108 & 368.1 & 565.8 & 4.7 & 4.6 & 19.5 & 20.6 & 20.6 & 100.2 & 395.3 \\
\hline RL-W110 & 167.8 & 258.5 & 3.2 & 3.6 & 7.5 & 9.3 & 9.1 & 44.2 & 181.4 \\
\hline RL-W114 & 13.7 & 21.2 & 1 & .1 & .7 & .7 & .7 & 3.7 & 14.8 \\
\hline RL-W115 & 41.4 & 63.8 & 8 & .9 & 1.8 & 2.3 & 2.2 & 10.9 & 44.8 \\
\hline RL-W116 & 38.2 & 58.8 & 7 & 8 & 1.7 & 2.1 & 2 & 10 & 41.2 \\
\hline RL-W117 & 9.8 & 15.2 & .1 & .2 & .4 & .5 & .5 & 2.6 & 10.6 \\
\hline RL-W118 & 51.8 & 79.8 & 1 & 1.1 & 2.3 & 2.8 & 2.8 & 13.6 & 56 \\
\hline RL-W119 & 51.4 & 99 & .6 & .2 & .5 & .6 & .5 & 1.1 & 95.3 \\
\hline RL-W120 & 51.4 & 99 & .6 & 2 & .5 & .6 & .5 & 1.1 & 95.3 \\
\hline RL-W121 & 54 & 104 & .6 & 3 & .5 & .6 & .6 & 1.2 & 100 \\
\hline RL-W122 & 617.1 & 1,189 & 7.2 & 3.4 & 6.4 & 7.3 & 6.8 & 14 & $1,143.7$ \\
\hline RL-W123 & 211.8 & 408.2 & 2.4 & 1.1 & 2.2 & 2.5 & 2.3 & 4.8 & 392.6 \\
\hline RL-W124 & 82.8 & 127.3 & 1 & 1 & 4.3 & 4.6 & 4.6 & 22.5 & 88.9 \\
\hline RL-W125 & 51.8 & 79.8 & 1 & 1.1 & 2.3 & 2.8 & 2.8 & 13.6 & 56 \\
\hline RL-W 126 & 9.8 & 15.2 & .1 & 2 & .4 & .5 & .5 & 2.6 & 10.6 \\
\hline RL-W127 & 10.2 & 15.8 & .2 & .2 & .4 & .5 & .5 & 2.7 & 11.1 \\
\hline
\end{tabular}




\begin{tabular}{|c|c|c|c|c|c|c|c|c|c|}
\hline $\begin{array}{l}\text { Unique } \\
\text { Identifier }\end{array}$ & 20 Year & $\begin{array}{l}\text { Calcu- } \\
\text { lated } \\
\text { Proj: }\end{array}$ & 1993 & 1994 & 1995 & 1996 & 1997 & $\begin{array}{l}1990^{\circ} \\
2002\end{array}$ & $\begin{array}{l}2003- \\
2022\end{array}$ \\
\hline RL-W128 & 10.2 & 15.8 & .2 & .2 & 4 & .5 & .5 & 2.7 & 11.1 \\
\hline RL-W129 & 41.1 & 63.4 & .8 & .9 & 1.8 & 2.2 & 2.2 & 10.8 & 44.5 \\
\hline RL-W130 & 118.9 & 182.8 & 1.5 & 1.4 & 6.3 & 6.6 & 6.6 & 32.4 & 127.7 \\
\hline RL-W131 & 9.8 & 15.2 & .1 & .2 & .4 & .5 & .5 & 2.6 & 10.6 \\
\hline RL-W132 & 13.7 & 21.2 & .1 & .1 & .7 & .7 & .7 & 3.7 & 14.8 \\
\hline RL-W133 & 203.5 & 274 & 3 & 4 & 26 & 16 & 16 & 68 & 141 \\
\hline RL-W134 & 8.5 & 11 & & .6 & .7 & .3 & .4 & 3.6 & 5 \\
\hline RL-W135 & 41.2 & 53.5 & .2 & 2.9 & 3.7 & 1.9 & 2.3 & 17.9 & 24.4 \\
\hline RL-W139 & 324.5 & 448.7 & 19.6 & 16.8 & 18.2 & 24.1 & 26.4 & 95 & 248.3 \\
\hline SL-W001 & 4.4 & 4.5 & .2 & 1.4 & 1.4 & .6 & .5 & .2 & .2 \\
\hline SL-W002 & 6.7 & 8.2 & .4 & .4 & .5 & .5 & 1 & 2 & 3 \\
\hline SL-W003 & 7.3 & 7.9 & .5 & .7 & 1 & 1.2 & 1.5 & 1.7 & 1.1 \\
\hline SL-W004 & 2.9 & 3.2 & .3 & .3 & 4 & .4 & .5 & .5 & .6 \\
\hline SL-W005 & 75.8 & 83.1 & 8.5 & 9.7 & 11 & 12.2 & 13 & 14 & 14.5 \\
\hline SL-W006 & 5.3 & 6 & .3 & .5 & .7 & .9 & 1.1 & 1.2 & 1.3 \\
\hline SR-W001 & 8 & 2 & .4 & .4 & .4 & .4 & .4 & & \\
\hline SR-W002 & 12 & 3 & .6 & .6 & .6 & .6 & .6 & & \\
\hline SR-W003 & 8 & 12 & .4 & .4 & 4 & .4 & .4 & 2 & 8 \\
\hline SR-W007 & 1,500 & 375 & 75 & 75 & 75 & 75 & 75 & & \\
\hline SR-W008 & 1,500 & 375 & 75 & 75 & 75 & 75 & 75 & & \\
\hline SR-W012 & 4 & 1 & .2 & .2 & .2 & .2 & .2 & & \\
\hline SR-W024 & 1.4 & 2.2 & & & .2 & & & .4 & 1.6 \\
\hline SR-W042 & 20 & 5 & 1 & 1 & 1 & 1 & 1 & & \\
\hline SR-W043 & 10 & 2.5 & .5 & .5 & .5 & .5 & .5 & & \\
\hline SR-W046 & 527 & 837 & & & & 31 & 31 & 155 & 620 \\
\hline SR-W047 & 3,400 & 5,400 & & & & 200 & 200 & 1,000 & 4,000 \\
\hline SR-W050 & 1.9 & .4 & & .1 & .1 & .1 & .1 & & \\
\hline WV-W002 & .7 & .1 & & & & & & & \\
\hline WV-W003 & .2 & & & & & & & & \\
\hline WV-W004 & 10 & 2.5 & .5 & .5 & .5 & .5 & .5 & & \\
\hline \multicolumn{10}{|l|}{ WV-W009 } \\
\hline WV-W010 & .1 & & & & & & & & \\
\hline WV-W013 & .2 & & & & & & & & \\
\hline WV-W014 & .2 & & & & & & & & \\
\hline WV-W015 & .4 & .1 & & & & & & & \\
\hline WV-W017 & .4 & .1 & & & & & & & \\
\hline WV-W019 & 13.3 & 3.3 & .6 & .6 & .6 & .6 & .6 & & \\
\hline \multicolumn{10}{|l|}{ WV-W020 } \\
\hline WV-W037 & & & & & & & & & \\
\hline
\end{tabular}


Table C-3: Projected Volume Based on Mass Projections

\begin{tabular}{|l|c|}
\hline Unique ID & 20 Year \\
\hline DP-W001 & 957.5 \\
\hline DP-W002 & 43.6 \\
\hline DP-W004 & 576.1 \\
\hline DP-W005 & $1,320.7$ \\
\hline DP-W006 & $1,728.5$ \\
\hline DP-W007 & $1,453.4$ \\
\hline DP-W016 & 2.2 \\
\hline DP-W017 & 52.4 \\
\hline DP-W018 & 1 \\
\hline DP-W021 & .2 \\
\hline DP-W026 & 22.1 \\
\hline DP-W027 & 400.8 \\
\hline DP-W030 & 67.9 \\
\hline DP-W032 & 198 \\
\hline DP-W033 & 213 \\
\hline DP-W034 & 187.5 \\
\hline DP-W035 & 124 \\
\hline DP-W038 & 37.2 \\
\hline DP-W039 & $6,110.2$ \\
\hline DP-W042 & $8,260.1$ \\
\hline DP-W043 & 8.2 \\
\hline DP-W050 & \\
\hline DP-W051 & 3 \\
\hline DP-W052 & .1 \\
\hline DP-W053 & .2 \\
\hline DP-W055 & 100.3 \\
\hline DP-W057 & 54.5 \\
\hline DP-W058 & 40.5 \\
\hline DP-W063 & 361.8 \\
\hline DP-W064 & 48.8 \\
\hline DP-W066 & 31.6 \\
\hline DP-W067 & 19.5 \\
\hline DP-W068 & 518.7 \\
\hline DP-W069 & 189.2 \\
\hline DP-W070 & 30.3 \\
\hline DP-W071 & 1 \\
\hline DP-W072 & \\
\hline DP-W073 & \\
\hline DP-W075 & .5 \\
\hline DP-W076 & 3.8 \\
\hline DP-W079 & 3.5 \\
\hline DP-W080 & 2.6 \\
\hline DP-W083 & 101.5 \\
\hline FP-W084 & 22 \\
\hline FM-W011 & 4.3 \\
\hline
\end{tabular}

\begin{tabular}{|l|r|}
\hline Unique 10 & 20 Year \\
\hline FM-W013 & .8 \\
\hline FM-W015 & .5 \\
\hline FM-W016 & .4 \\
\hline FM-W017 & .2 \\
\hline FM-W018 & .1 \\
\hline FM-W019 & .5 \\
\hline FM-W020 & .7 \\
\hline FM-W021 & .5 \\
\hline FM-W022 & .1 \\
\hline FM-W024 & 1.6 \\
\hline FM-W028 & .1 \\
\hline FM-W030 & 1 \\
\hline FM-W031 & .4 \\
\hline FM-W034 & \\
\hline FM-W035 & .1 \\
\hline FM-W036 & 4.2 \\
\hline FM-W040 & .4 \\
\hline FM-W050 & 1.1 \\
\hline FM-W082 & .2 \\
\hline FM-W089 & .7 \\
\hline FM-W094 & 2 \\
\hline FM-W101 & 1.3 \\
\hline FM-W107 & 3.3 \\
\hline FM-W117 & .4 \\
\hline FM-W124 & .2 \\
\hline FM-W288 & 2.5 \\
\hline FM-W289 & .4 \\
\hline OR-W002 & 25.3 \\
\hline OR-W003 & .2 \\
\hline OR-W004 & 1.4 \\
\hline OR-W005 & 162.6 \\
\hline OR-W006 & .9 \\
\hline OR-W007 & \\
\hline OR-W009 & 220.2 \\
\hline OR-W010 & 23.4 \\
\hline OR-W011 & 91.8 \\
\hline OR-W013 & 198.4 \\
\hline OR-W014 & 4.1 \\
\hline OR-W015 & 18.8 \\
\hline OR-W016 & .8 \\
\hline OR-W018 & 26.6 \\
\hline OR-W019 & 59.1 \\
\hline OR-W020 & 2.9 \\
\hline OR-W023 & 25.4 \\
\hline OR-W026 & .3 \\
\hline
\end{tabular}

\begin{tabular}{|l|r|}
\hline Unique ID & 20 Year \\
\hline OR-W031 & \\
\hline OR-W033 & .7 \\
\hline OR-W034 & 31.2 \\
\hline OR-W035 & 2.1 \\
\hline OR-W036 & 76.1 \\
\hline YP-W003 & 68.7 \\
\hline YP-W004 & .1 \\
\hline YP-W005 & $2,786.9$ \\
\hline YP-W008 & \\
\hline YP-W009 & 221.7 \\
\hline YP-W010 & \\
\hline YP-W011 & .4 \\
\hline YP-W012 & 3.2 \\
\hline YP-W013 & 51.3 \\
\hline YP-W014 & \\
\hline YP-W015 & 2.6 \\
\hline YP-W019 & 21.9 \\
\hline YP-W020 & 55.9 \\
\hline YP-W022 & 6.1 \\
\hline YP-W025 & .7 \\
\hline YP-W027 & 8.1 \\
\hline YP-W028 & .6 \\
\hline YP-W030 & 1.6 \\
\hline YP-W031 & 40.9 \\
\hline YP-W032 & .9 \\
\hline YP-W035 & .1 \\
\hline YP-W036 & \\
\hline YP-W037 & 2.1 \\
\hline YP-W040 & 2.4 \\
\hline YP-W041 & 3.9 \\
\hline YP-W042 & 1.8 \\
\hline YP-W043 & .2 \\
\hline YP-W044 & .3 \\
\hline YP-W045 & .8 \\
\hline YP-W048 & .1 \\
\hline YP-W049 & 8.8 \\
\hline YP-W050 & \\
\hline YP-W051 & \\
\hline YP-W052 & 1.6 \\
\hline YP-W054 & 1.6 \\
\hline YP-W056 & 1.8 \\
\hline YP-W058 & 1.1 \\
\hline YP-W059 & .8 \\
\hline YP-W060 & 1 \\
\hline
\end{tabular}

\begin{tabular}{|l|c|}
\hline Unique ID & 20 Year \\
\hline YP-W064 & \\
\hline YP-W065 & 87.9 \\
\hline YP-W067 & 8 \\
\hline YP-W068 & 82.8 \\
\hline YP-W069 & 78.4 \\
\hline YP-W070 & 18.7 \\
\hline YP-W071 & .2 \\
\hline YP-W072 & 269.8 \\
\hline YP-W073 & 98 \\
\hline YP-W074 & 3.2 \\
\hline YP-W076 & \\
\hline YP-W077 & 6.7 \\
\hline YP-W078 & 89.5 \\
\hline YP-W079 & 7.5 \\
\hline YP-W082 & 91.9 \\
\hline YP-W083 & 30.5 \\
\hline YP-W084 & 139.2 \\
\hline YP-W085 & 3.4 \\
\hline YP-W087 & .4 \\
\hline YP-W088 & .1 \\
\hline YP-W091 & 30.8 \\
\hline YP-W093 & 73.2 \\
\hline YP-W095 & 6.6 \\
\hline YP-W096 & 3.3 \\
\hline YP-W097 & 149.3 \\
\hline YP-W098 & .6 \\
\hline YP-W102 & 7.2 \\
\hline YP-W105 & .3 \\
\hline YP-W106 & .1 \\
\hline YP-W107 & 25.9 \\
\hline YP-W108 & .1 \\
\hline YP-W109 & 10.2 \\
\hline YP-W110 & .8 \\
\hline YP-W111 & 1.9 \\
\hline YP-W112 & \\
\hline YP-W113 & \\
\hline YP-W114 & .1 \\
\hline YP-W116 & \\
\hline YP-W117 & 5.1 \\
\hline YP-W120 & .9 \\
\hline YP-W121 & .6 \\
\hline YP-W124 & 4.2 \\
\hline YP-W125 & 1.3 \\
\hline YP-W126 & 2 \\
\hline YP-W129 & 34 \\
\hline YP-W136 & 21.1 \\
\hline
\end{tabular}




\begin{tabular}{|l|r|}
\hline Unique ID & 20 Year \\
\hline YP-W137 & 175.5 \\
\hline YP-W139 & \\
\hline YP-W140 & 4.3 \\
\hline YP-W141 & 5.9 \\
\hline YP-W143 & 12.5 \\
\hline YP-W144 & 3.2 \\
\hline YP-W145 & 409.8 \\
\hline
\end{tabular}

\begin{tabular}{|l|r|}
\hline Unique ID & 20 Year \\
\hline YP-W146 & 1.6 \\
\hline YP-W147 & 4.5 \\
\hline YP-W148 & .8 \\
\hline YP-W149 & 8.9 \\
\hline YP-W151 & 97.1 \\
\hline YP-W152 & 4.1 \\
\hline YP-W153 & 6.8 \\
\hline
\end{tabular}

\begin{tabular}{|l|r|}
\hline Unique ID & 20 Year \\
\hline YP-W154 & 1.2 \\
\hline YP-W157 & .1 \\
\hline YP-W158 & .1 \\
\hline YP-W159 & \\
\hline YP-W161 & .4 \\
\hline YP-W162 & \\
\hline YP-W163 & 7 \\
\hline
\end{tabular}

\begin{tabular}{|l|r|}
\hline Unique ID & 20 Year \\
\hline YP-W164 & 3.2 \\
\hline YP-W165 & .6 \\
\hline YP-W168 & 11 \\
\hline YP-W170 & .5 \\
\hline
\end{tabular}




\section{Appendix D - Process Flow Diagrams}

The following set of figures includes the upper level flow diagrams for the three different MLLW cases as well as the TRU cases. These are better described in "Analysis of Waste Treatment Requirements for DOE Mixed Wastes: Technical Basis" by Burdon Musgrave. The diagrams show the connections between each of the unit operations but do not show how the waste moves through them and the splitting of the waste streams. In some places, values are noted for the portion of the waste sent to a location, but, this is a general condition and may vary for specific waste streams. The Argonne National Laboratory waste stream numbers are shown below each of the major inputs. 


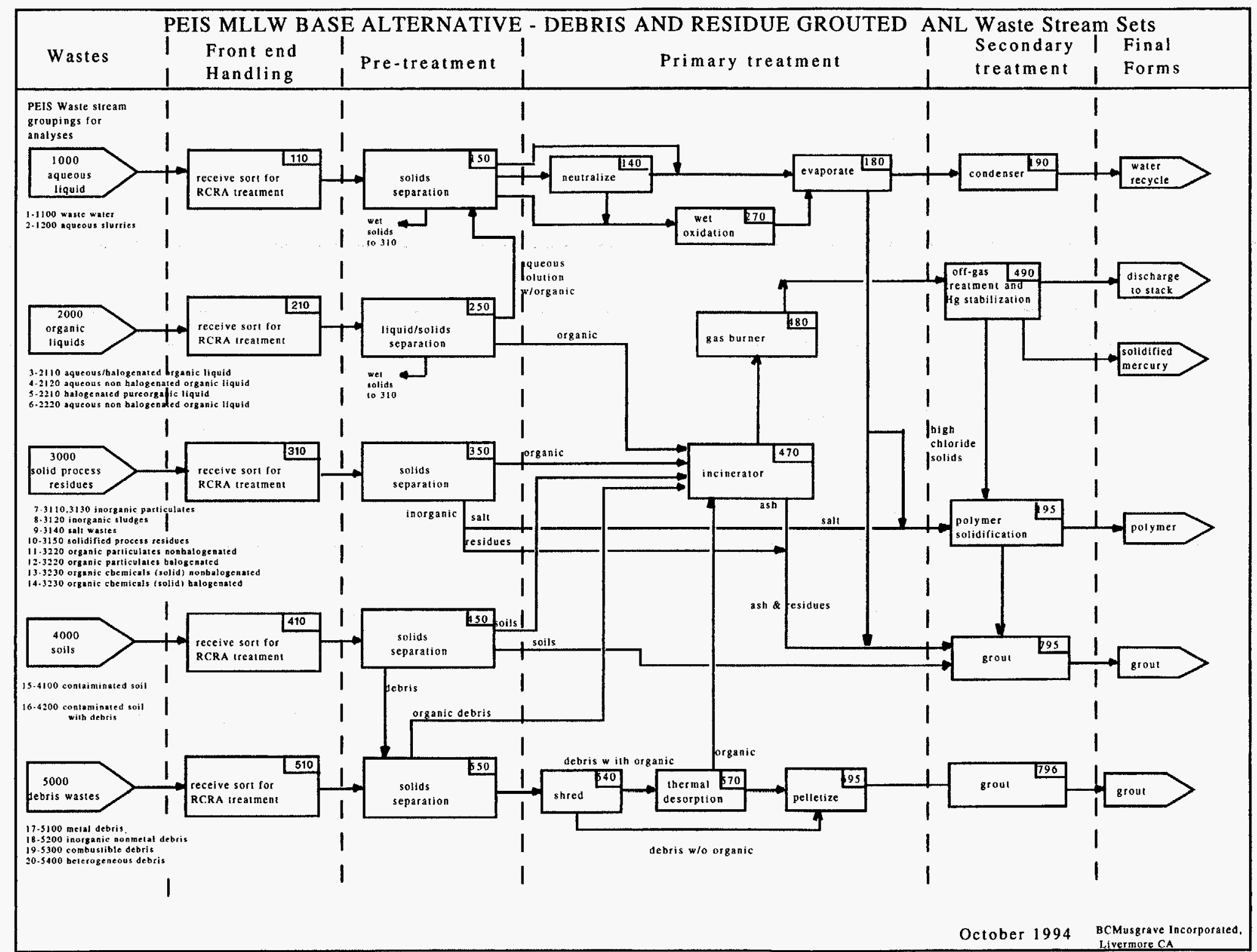

Figure D-1. Base Case Matrices 1000-5000 


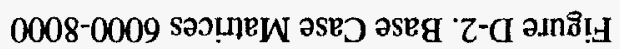

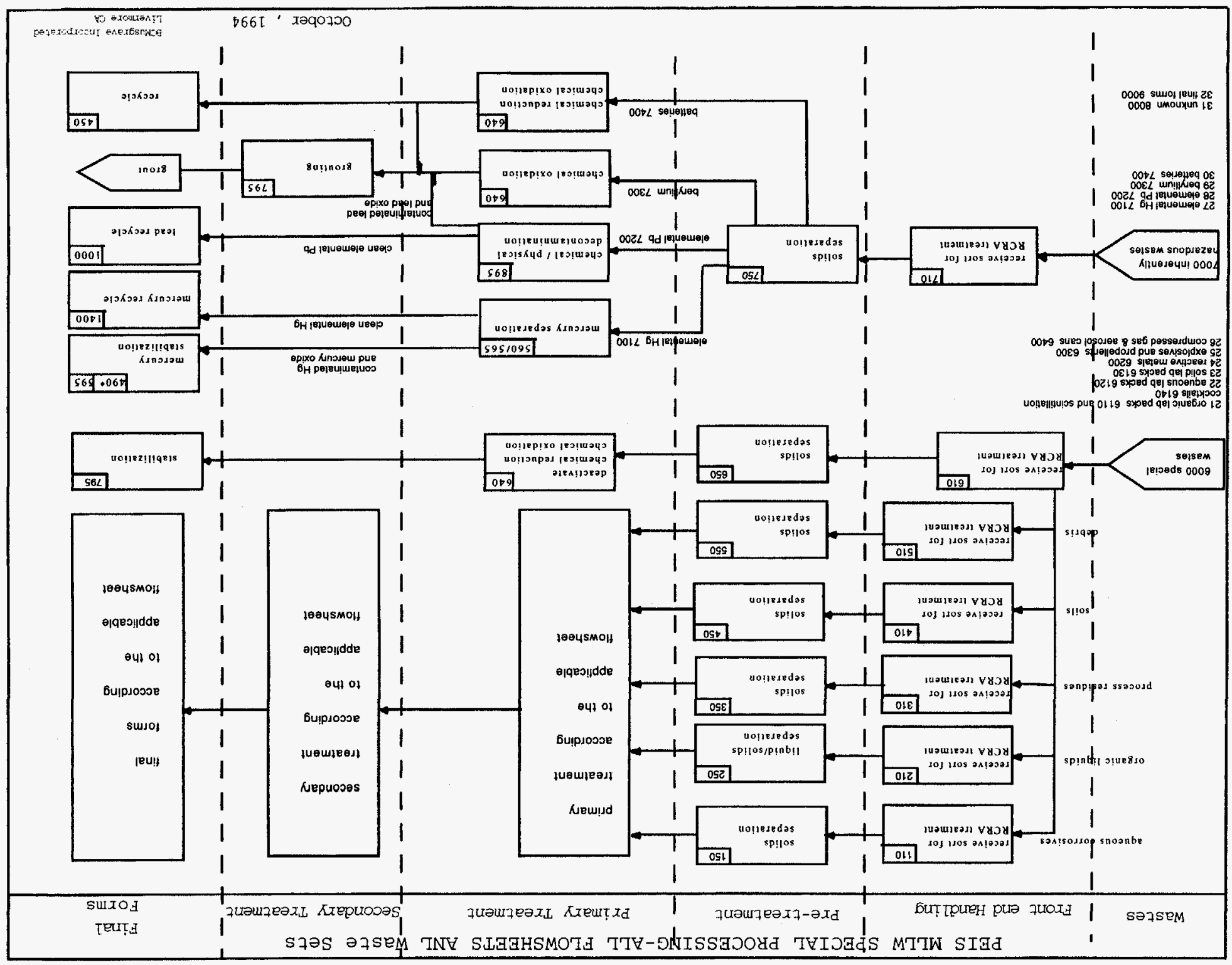




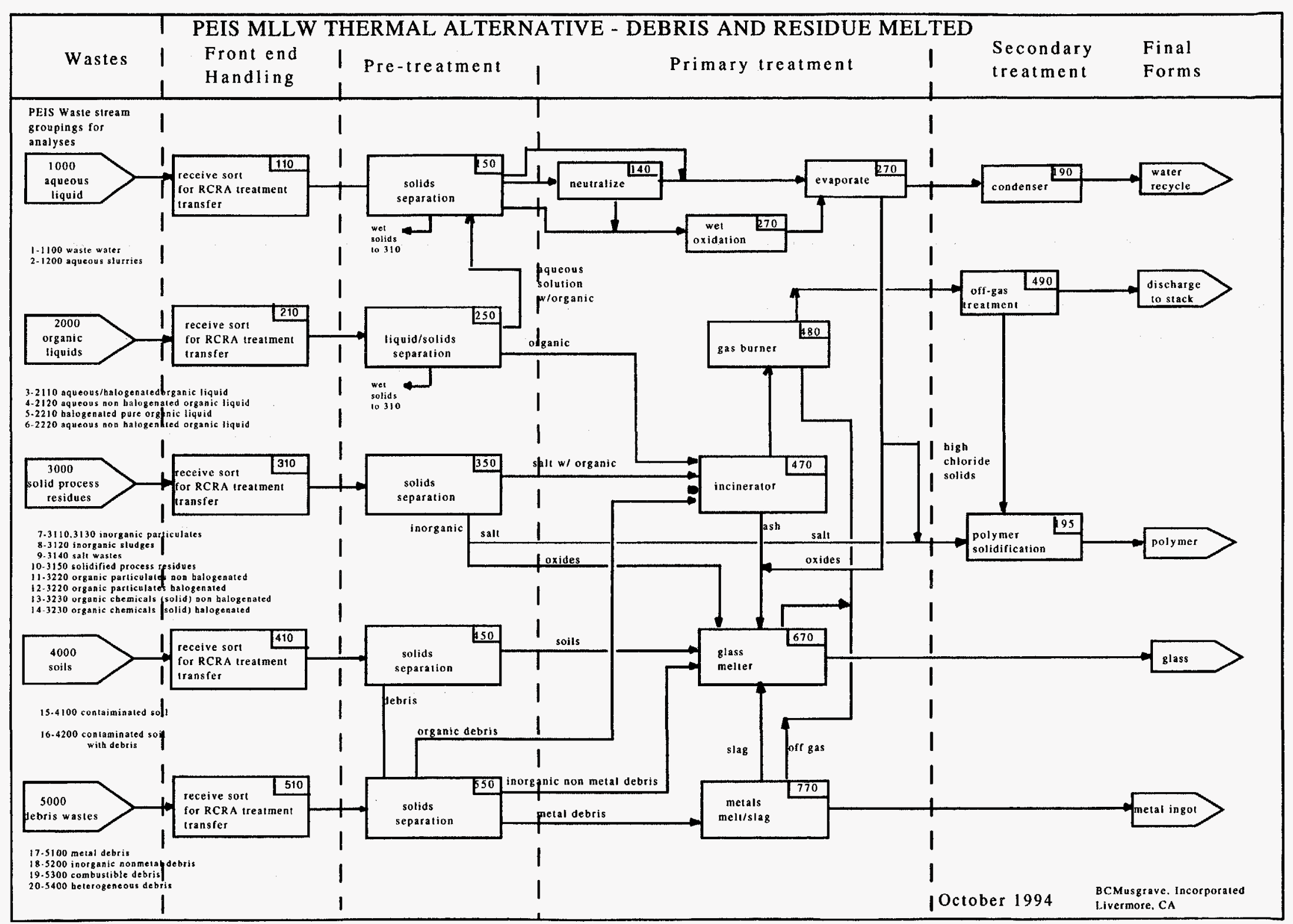

Figure D-3 Thermal Matrices 1000-5000 


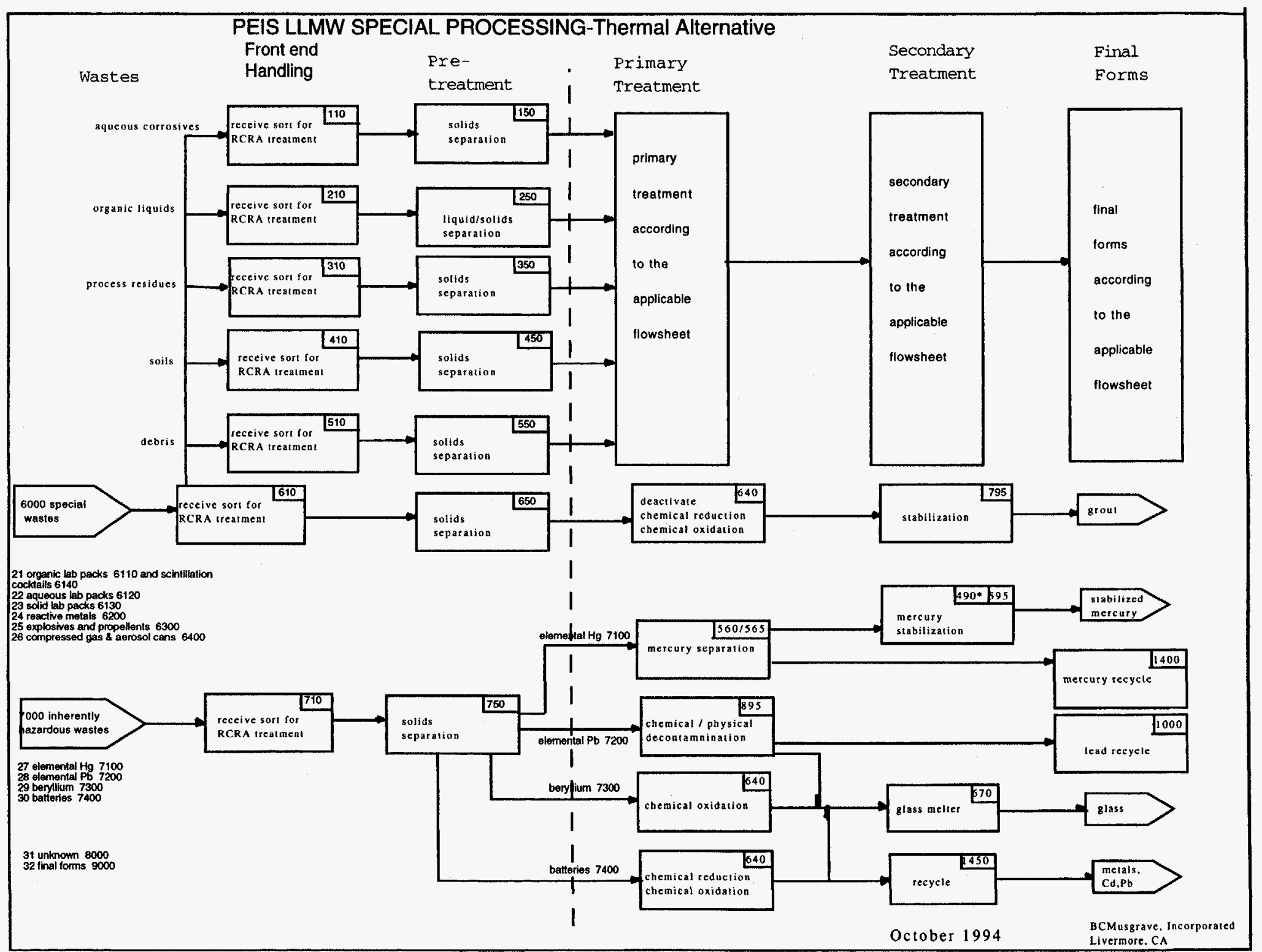

Figure D-4. Thermal Matrices Matrices 6000-8000 
Appendix-32

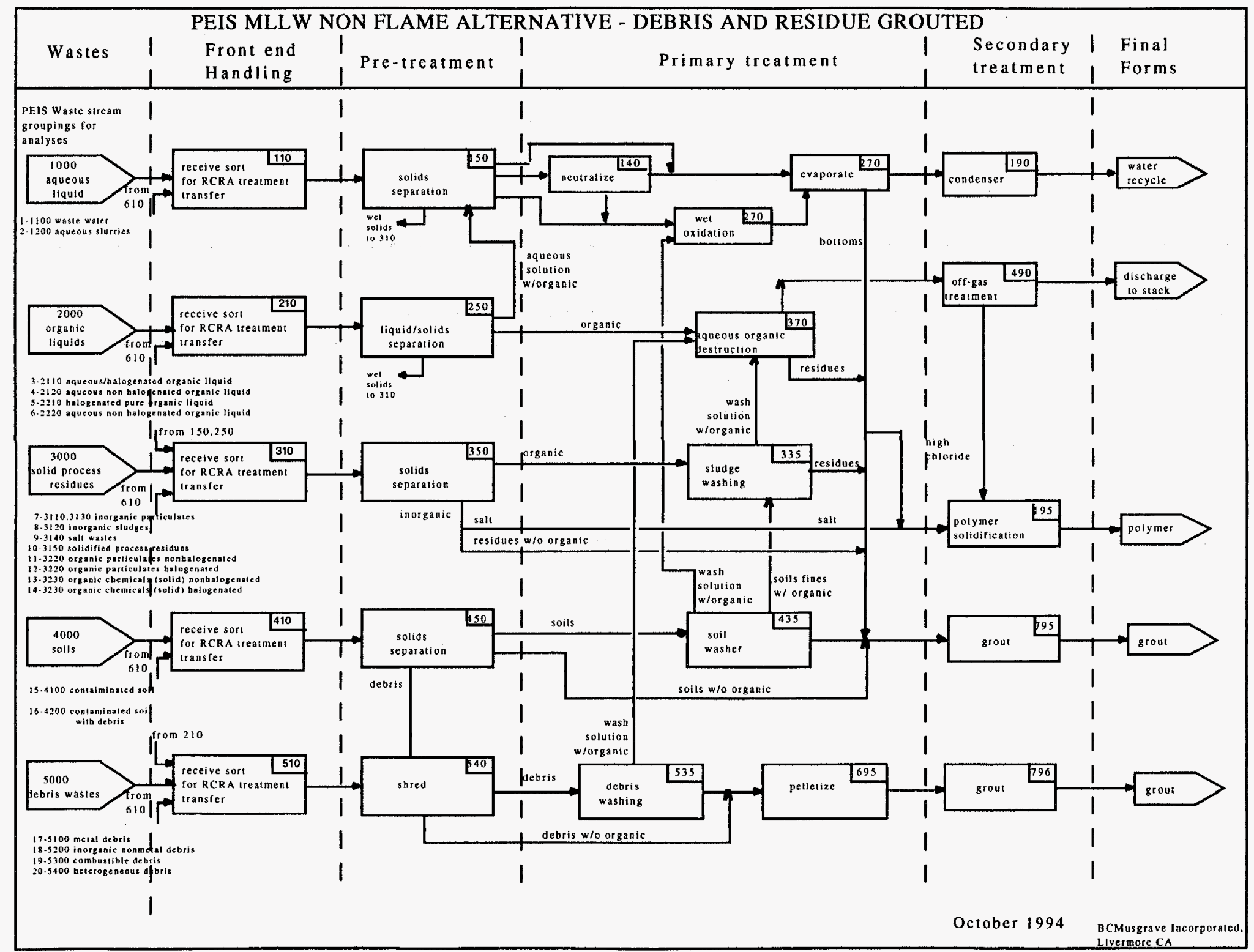

Figure D-5. Nonthermal Matrices 1000-5000 


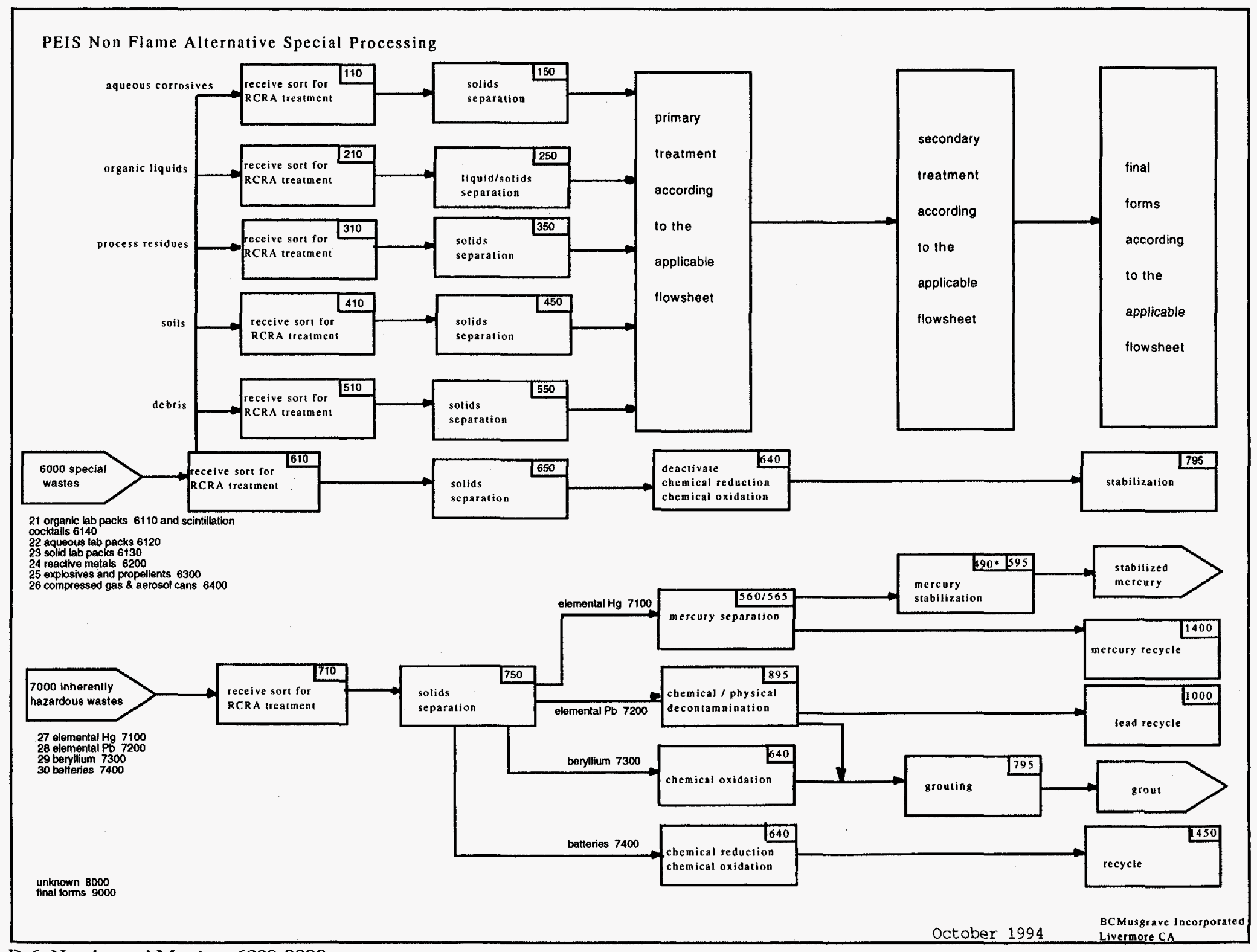

Figure D-6. Nonthermal Matrices 6000-8000 


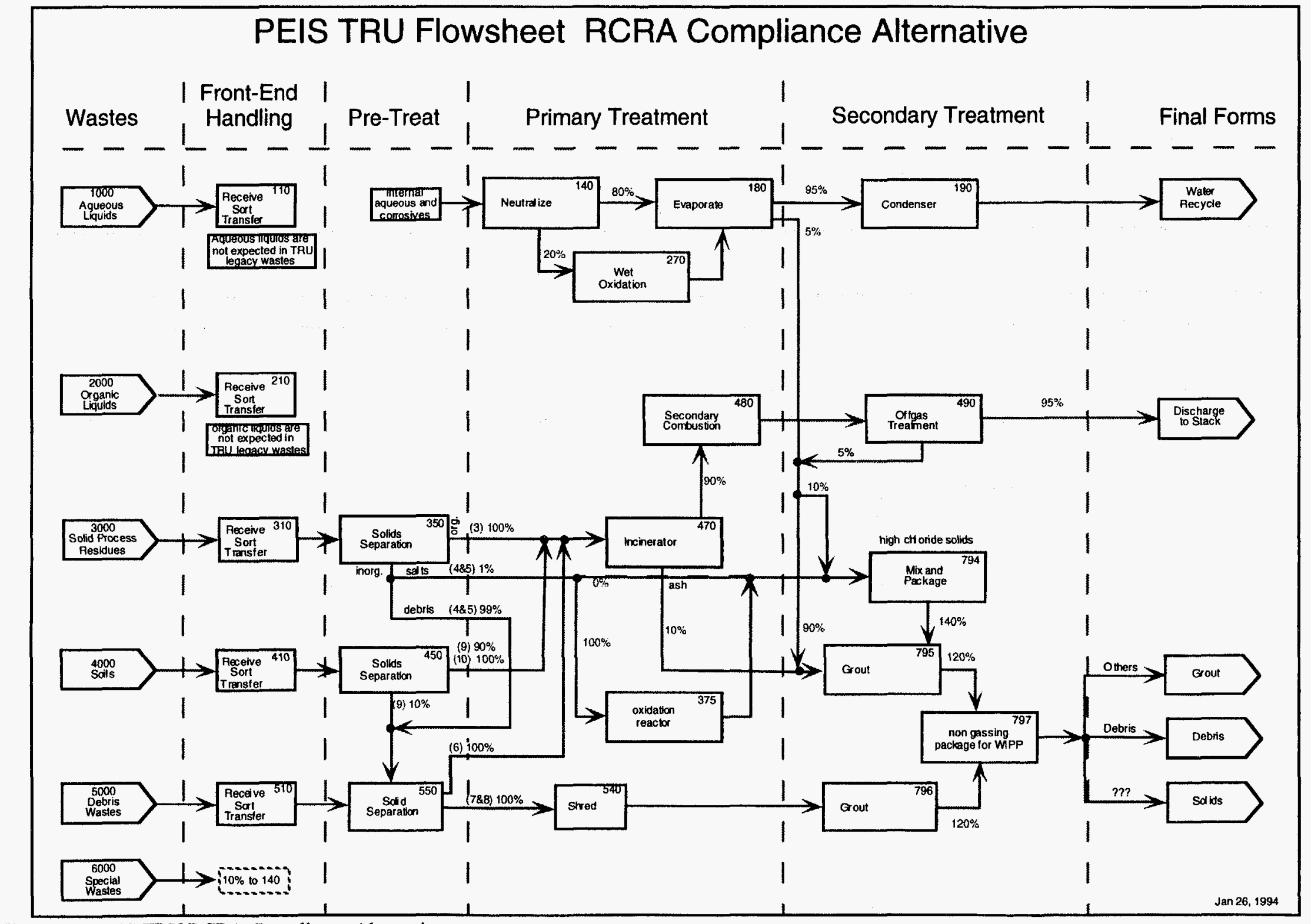




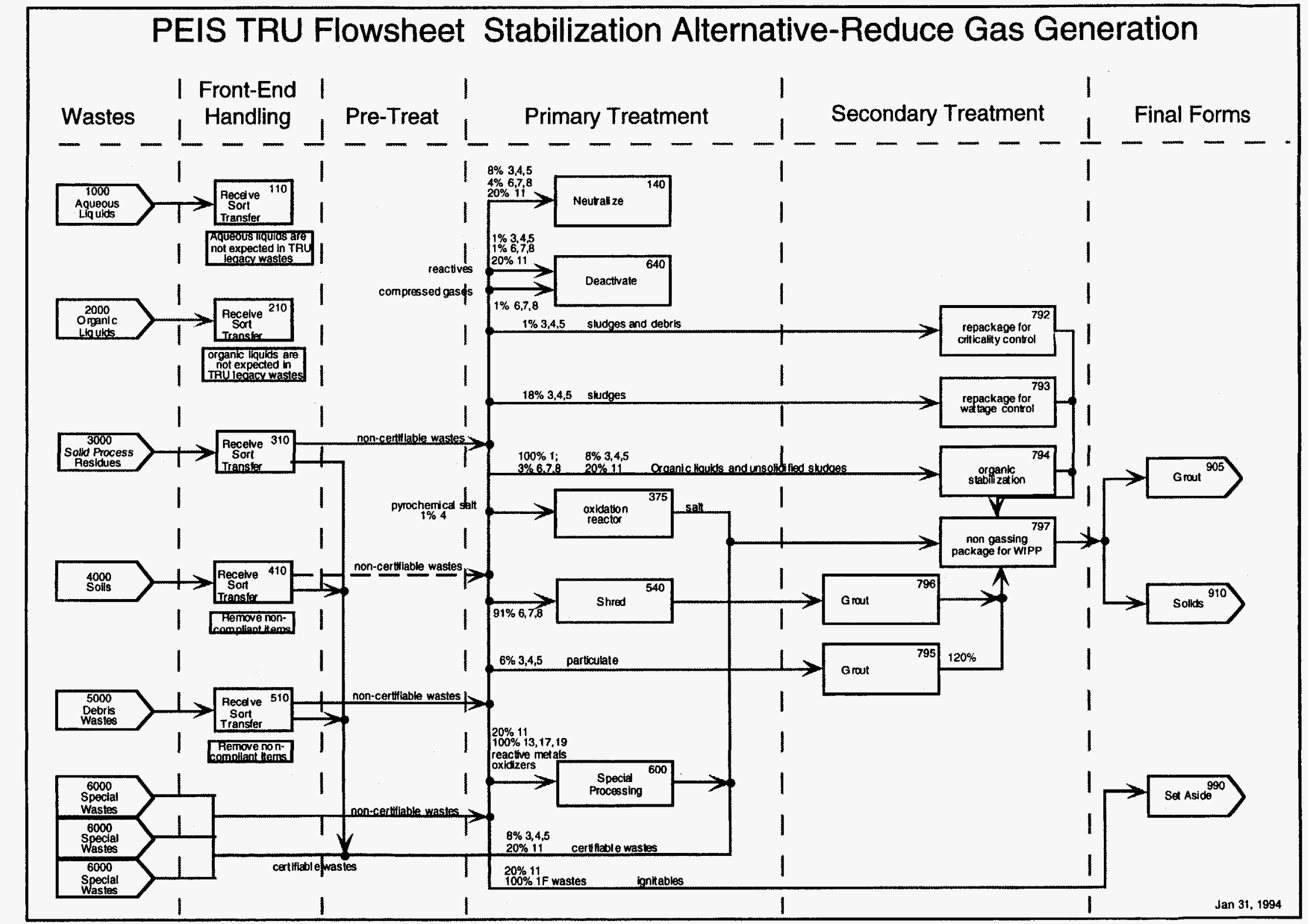

Figure D-8 WTPP Waste Acceptance Criteria 


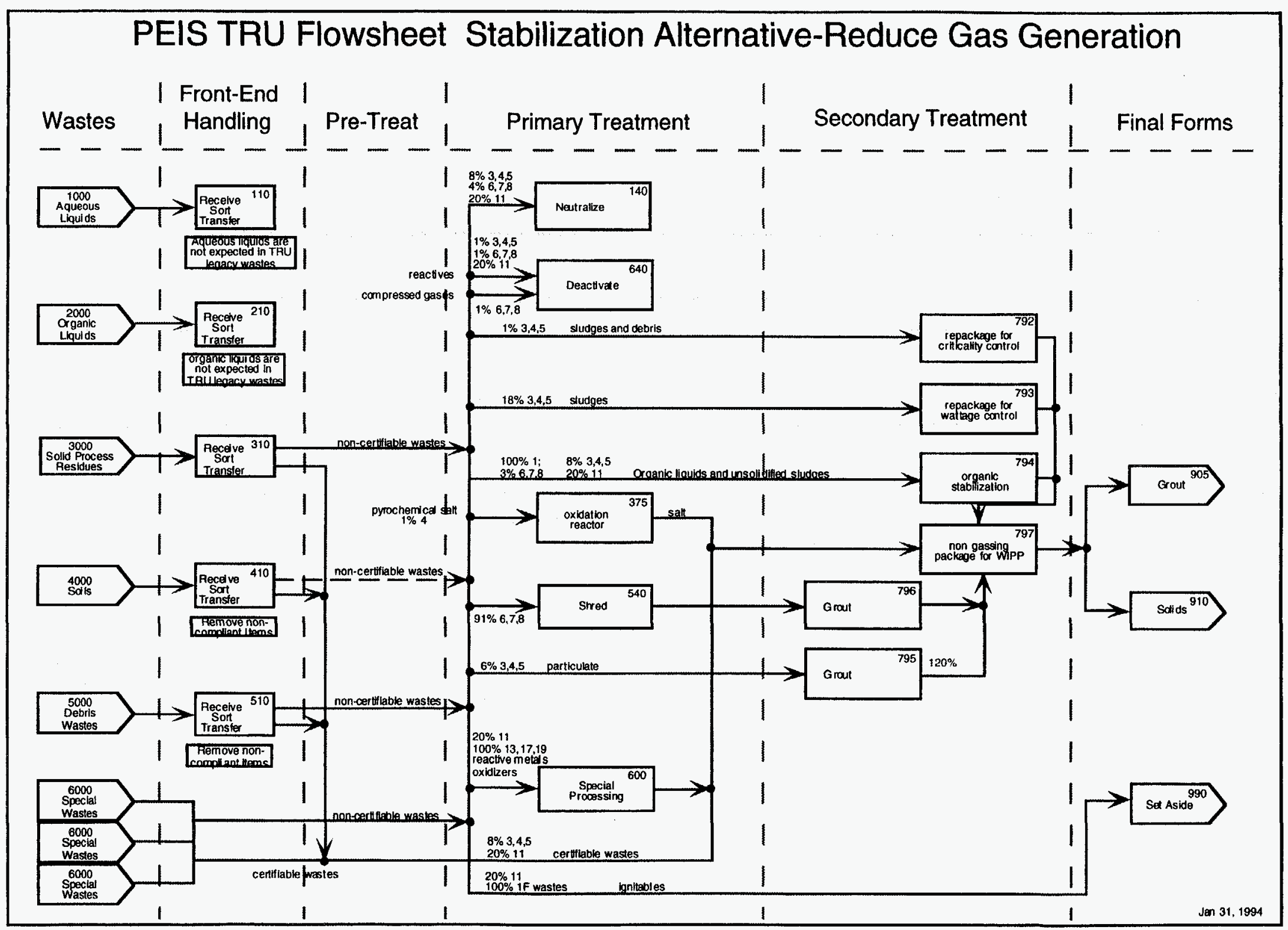

Figure D-9 WIPP WAC Reduced Gas Generation 